\title{
Wirkung föderaler Strukturen in der staatlichen Innovationsförderung
}

\author{
Dissertation \\ zur Erlangung des wirtschaftswissenschaftlichen Doktorgrades \\ der Wirtschaftswissenschaftlichen Fakultät \\ der Universität Göttingen
}

vorgelegt von

Lasse Becker

aus Kassel

Göttingen, 2015 
$\begin{array}{ll}\text { Erstgutachter } & \text { Prof. Dr. Kilian Bizer } \\ \text { Zweitgutachter } & \text { Prof. Dr. Markus Spiwoks }\end{array}$

Tag der mündlichen Prüfung: 6. Juli 2015 


\section{Danksagung}

Mein Dank gilt den vielen Personen, die in den Jahren meines Promotionsvorhabens meinen Weg gekreuzt haben. Zuallererst natürlich meinem Promotionsbetreuer Prof. Dr. Kilian Bizer, der meine Promotion über den gesamten Zeitraum aktiv begleitet und immer wieder Impulse gegeben hat. Mein Dank gilt auch Prof. Dr. Markus Spiwoks als Zweitgutachter und Prof. Dr. Maik Hammerschmidt als Drittprüfer sowie allen Kolleginnen und Kollegen der letzten Jahre an der Professur für Wirtschaftspolitik und Mittelstandsforschung.

Impulsgeberin, mich mit staatlicher Innovationsförderung zu beschäftigen, war Dr. Verena Mertins und die Idee, dies mit dem Thema Föderalismus zu verknüpfen, kam nicht zuletzt wegen der Arbeiten von Dr. Petra Enß. Beiden möchte ich für diese Inspiration danken.

Dankbar bin ich dem Team des KMU-Netzwerks bzw. der Göttinger Graduiertenschule Gesellschaftswissenschaften um Dr. Bettina Roß und Christina Qaim, mit denen ich in meiner Funktion als Projektkoordinator zusammenarbeiten durfte. Mein Dank gilt auch der FriedrichNaumann-Stiftung für die Freiheit, die mich anschließend für die Förderung durch ein Promotionsstipendium ausgewählt hat. Diese Arbeit wurde somit durch die Friedrich-NaumannStiftung für die Freiheit und das Bundesministerium für Bildung und Forschung unterstützt. Innerhalb der Stiftung gilt mein besonderer Dank Ingrid Hirthe, aber auch Dr. Susanne Liermann und Dr. Christian Taaks. Für das Nachtquartier bei Forschungsaufenthalten beim ZEW und Eurostat danke ich außerdem Dr. Jens Brandenburg und Dr. Franziska Ziegelmeyer.

In den vergangenen Jahren haben einige Personen über die Papiere sprachlich Korrektur gelesen, neben dem professionellen Lektorat möchte ich dafür Mona Model, Nathalie Meyer, Alexander Pokorny, Peter Wilkinson, Anna-Catharina Müller, Elias Knell sowie meinem Bruder Dr. Kalle Becker danken. Zutiefst dankbar bin ich auch meinen Freunden Mona Model, Dr. Rabi Raj Datta, Johannes Vogel, Dr. habil. Stefan Ruppert, Dr. Eva Scharbatke, Johannes Wolf, Laura Betz, Anna-Catharina Müller und last but definitely not least Nathalie Meyer, die gerade wenn es stockte für mich da waren und mich unterstützt haben.

Mein größter Dank gilt Klaus und Petra Becker, meinen Eltern. Nicht nur, weil sie viele Teile dieser Arbeit Korrektur gelesen haben, sondern weil sie für mich da waren, mich mit Rat und Tat unterstützt haben, mir ein sicherer Rückhalt waren und mich immer gefördert und unterstützt haben. Ohne sie hätte ich mir nicht die Freiheit nehmen können, diese Dissertation voranzutreiben und abschließen zu können. Ich widme ihnen diese Arbeit.

Göttingen, im Juli 2015

Lasse Becker 
Meinen Eltern 


\section{Inhaltsverzeichnis}

$\begin{array}{ll}\text { Kapitel } 1 & 1\end{array}$

Einleitung und Überblick über die Einzelbeiträge

Kapitel 2

No gains of federalism in innovation support? The case of Germany

Veröffentlicht in: DRUID Society (Hg.): Conference Proceedings 35th DRUID

Celebration Conference 2013. 35th DRUID Celebration Conference 2013.

Barcelona. DRUID society: online:

http://druid8.sit.aau.dk/druid/acc_papers/rv1s78ke8jm7n4/rad6udnov2b/d.pdf

im Juni 2013

Kapitel 3:

52

Federalism and innovation support for small and medium-sized enterprises:

Empirical evidence in Europe

(mit Kilian Bizer, Hauptautor: Lasse Becker mit ca. 90 Prozent)

Eingereicht bei Research Policy

cege Discussion Paper No. 245

Kapitel 4:

88

Effectiveness of public innovation support in Europe: Does public support

foster turnover, employment and labour productivity?

Eingereicht bei Journal of Evolutionary Economics

cege Discussion Paper No. 236

Kapitel 5:

Föderalismus in der staatlichen Innovationsförderung: Wirkung föderaler

Strukturen und ihre Politikimplikationen

(mit Kilian Bizer, Hauptautor: Lasse Becker mit ca. 90 Prozent)

Veröffentlicht in: Wirtschaftsdienst, 95. Jg. (2015), H. 6, S.411-416

im Juni 2015

DOI: $10.1007 / \mathrm{s} 10273-015-1840-9$ 


\section{Weitere Veröffentlichungen außerhalb dieser Dissertation Veröffentlichungen mit externer wissenschaftlicher Begutachtung}

Innovation subsidies in a federal system. Innovation policy at different political levels in Germany.

Veröffentlicht in: GSTF and Murray Hunter (Hg.): Proceedings of the 2nd annual

International Conference on Innovation and Entrepreneurship (IE 2012). Singapur:

GSTF, 59-64

Erschienen im Herbst 2012

Ausgezeichnet mit dem Best Student Paper Award der IE 2012

\section{Sonstige Veröffentlichungen}

Der persönlich haftende Unternehmer in der Marktwirtschaft. Göttingen:

Volkswirtschaftl. Inst. für Mittelstand und Handwerk (Göttinger

handwerkswirtschaftliche Arbeitshefte 60).

(mit Kilian Bizer, Hauptautor: Kilian Bizer mit ca. 80 Prozent)

Erschienen im Frühjahr 2008 
Kapitel 1

\section{Einleitung und Überblick über die Einzelbeiträge}





\section{$1 \quad$ Forschung zu Innovationsförderung und Föderalismus}

„Innovationsstärke wird mehr als früher zum Schlüssel einer höheren Wettbewerbsfähigkeit. Die Hälfte aller Produkte, die wir in fünf Jahren verkaufen wollen, müssen wir erst entwickeln." Karl Heinz Beckurts (1930-86), Physiker und bis zu seiner Ermordung Forschungsleiter der Siemens AG

Diese Aussage des damaligen Forschungsleiters eines der größten forschungsintensiven Unternehmen in Deutschland zeigt einen der Eckpfeiler auf, der hinter den Überlegungen staatlicher Innovationsförderung steht: Innovationen erhöhen die Wettbewerbsfähigkeit. Der Prozess der kreativen Zerstörung, den Joseph A. Schumpeter (1942/2008: 81-6) beschreibt, sorgt dafür, dass die innovativen Unternehmen entstehen, bestehen und erfolgreich andere weniger innovative Unternehmen verdrängen. Politische Entscheider überall in der Welt nehmen dies zum Anlass, um die Innovationsfähigkeit ihrer Unternehmen unterstützen und fördern zu wollen. Vielfältige Förderprogramme, Initiativen und Rahmensetzungen sollen die Innovationskraft privater Unternehmen stärken und begünstigen. Im Durchschnitt der Europäischen Union verwendeten die Mitgliedsstaaten der Europäischen Union gemäß European Commission (2013) zwischen 2007 und 2012 14,2\% ihrer Ausgaben für staatliche Maßnahmen zur Unterstützung von Forschung, Entwicklung und Innovation. Vielfach wird die Förderung auf kleine und mittlere Unternehmen (KMU) konzentriert, da bei diesen stärkere Hindernisse zur Innovationstätigkeit vermutet werden.

Bisherige Untersuchungen zu Wirkungsweise und Effekten der Förderung ebenso wie zu den Charakteristika geförderter Unternehmen fokussieren hierbei vor allem auf die Analyse der Wirkungsweise der Förderung in einzelnen Ländern beziehungsweise einiger weniger Länder. Dies zeigt eine Forschungslücke auf dem Feld des Vergleichs einer größeren Anzahl unterschiedlicher Länder auf.

Daneben gehen bestehende Studien mit sehr wenigen Ausnahmen von einer homogenen Struktur der Förderung innerhalb eines Landes aus. Gerade die Analyse staatlicher Innovationsförderung erscheint jedoch allein mit Blick auf die unterschiedlichen politischen Systeme regional sehr verschieden zu sein. Im Besonderen föderale und semiföderale Systeme, wie Deutschland oder Spanien, legen einen Schwerpunkt auf die regionale Förderung von Innovationen, aber auch in zentralistischen Ländern, wie in Skandinavien, ist die Bedeutung regionaler Programme in den letzten Jahren gewachsen. Hieraus folgt eine weitere, noch umfassendere Forschungslücke zur Bedeutung der unterschiedlichen Programmebenen, die 
besonders mit Blick auf ihre Verzahnung, aber auch mit Blick auf ihre Wirkungsweise erfolgen sollte und stark mit der Frage der politischen Entscheidungsstrukturen in ihrem Land verknüpft ist.

Einen Beitrag zur Schließung dieser beiden Forschungslücken will die vorliegende Dissertation leisten, indem sie einerseits die Charakteristika geförderter Unternehmen in Deutschland untersucht - und insbesondere die Wirkung auf die Förderwahrscheinlichkeit kleiner und mittlerer Unternehmen hierbei in verschiedenen politischen Strukturen in den Mittelpunkt stellt und andererseits diese Untersuchung auf der europäischen Ebene fortsetzt. Auf beiden Ebenen sollen daneben auch Analysen der Effektivität der Förderung vorgenommen werden.

Das erste Kapitel gliedert sich dabei in drei Abschnitte mit sieben Unterabschnitten. Nach dieser Einleitung definiert der zweite Abschnitt anhand der bestehenden Literatur die verschiedenen Zusammenhänge, die für das Thema relevant sind: Im ersten Unterabschnitt wird anhand der Eigenschaften von Innovationen erläutert, wodurch staatliche Eingriffe zur Unterstützung privatwirtschaftlicher Innovationen zu rechtfertigen sind. Anhand bereits vorhandener Studien folgt ein Ausblick auf die Wirkungsweise staatlicher Innovationsförderung in Deutschland, Europa und darüber hinaus. Der zweite Unterabschnitt beleuchtet die theoretischen Gründe für föderale Strukturen im Allgemeinen anhand der Literatur und überträgt diese generelle Wirkungsweise dann auf das Feld der staatlichen Innovationsförderung und stellt die wenigen vorhandenen Studien zu diesem Thema vor. Im dritten Unterabschnitt wird die Bedeutung und Position kleinerer und mittlerer Unternehmen für die Innovationsfähigkeit ebenso wie die daraus abgeleiteten Schlüsse für die staatliche Innovationsförderung erläutert. Ferner werden bestehende empirische Arbeiten zur Innovationsförderung in kleinen und mittleren Unternehmen vorgestellt.

Im dritten Abschnitt dieser Einleitung werden dann in vier Unterabschnitten die vier Papiere dieser Dissertation kurz zusammengefasst und die Ergebnisse skizziert. Mit Blick auf die Implikationen für die Politik in Deutschland, aber auch in der Europäischen Union, ist hierfür der vierte Unterabschnitt, der sich auf das vierte und letzte Papier bezieht, von besonderer Bedeutung.

\section{Thematische Einführung}

\subsection{Private Innovationen und staatliche Innovationsförderung}

Bei Innovationen handelt es sich entsprechend des Oslo Manual der OECD (OECD 1997) um eine Neuerung auf Unternehmensebene. Zu unterscheiden sind hierbei als wichtigste Kategorien Produktinnovationen, bei denen es sich um ein neues oder merklich verbessertes 
Produkt (oder eine Dienstleistung) der Firma handelt, sowie Prozessinnovationen, bei denen es sich um die Neuerung einer Herstellungs- oder Verarbeitungstechnik im Rahmen des Produktionsprozesses eines Produkts oder einer Dienstleistung handelt. Als weitere Innovationskategorien werden in neueren Studien noch Organisationsinnovationen, bei denen eine Neuerung bei einem Organisationsprozess außerhalb des eigentlichen Herstellungsprozesses erfolgt, sowie Marketinginnovationen, bei denen ein Vertriebsweg oder -schritt von einer Neuerung betroffen ist, unterschieden.

All diesen privaten Innovationen ist gemein, dass sie zumindest teilweise Charakteristika öffentlicher Güter aufweisen: Die Nicht-Ausschließbarkeit der Nutzung von Innovationen ist generell problematisch und führt zu der in der Literatur umfassend diskutierten Problematik von intellektuellen Eigentumsrechten (vgl. mit Blick auf KMU Thomä und Bizer 2013). Auch die Nicht-Rivalität im Konsum ist mindestens bei einigen Innovationen - immer abhängig von den zugrunde liegenden Technologien - gegeben (vgl. Griliches 1992: 31).

Ein weiteres grundlegendes und zu Marktversagen führendes Problem bei Innovationen stellt die Unsicherheit des Erfolges dar: Vielfach ist im Vorfeld nicht abzusehen, ob ein Innovationsprojekt auch nur erfolgreich abgeschlossen werden kann, geschweige denn, ob das aus einer Innovation resultierende Produkt zu einem Erfolg am Markt wird. Diese Unsicherheit führt zur Reduzierung von Innovationstätigkeit, die insbesondere kleinere Unternehmen betrifft (vgl. Czarnitzki und Toole 2008). Die Intransparenz bei der Kenntnis von Innovationstätigkeiten anderer Unternehmen kann hierbei jedoch auch dazu führen, dass Unternehmen möglichst schnell und umfassend innovationstätig sind und dabei oberhalb ihres eigentlichen Bedarfs Innovationsmaßnahmen durchführen, um schneller als die Konkurrenz zu sein. All diese Aspekte führen zu einer privaten Innovationstätigkeit, die nicht dem gesellschaftlich optimalen Bereitstellungsniveau von Innovationen entspricht (vgl. Brouwer 2000: 150 sowie Grossman et al. 1994: 37-8).

Gerade vor dem Hintergrund des Problems eines möglicherweise zu niedrigen Innovationsniveaus sind staatliche Akteure mittels Subventionen und steuerlichen Erleichterungen aktiv, um Innovationen zu stimulieren. Gerechtfertigt wird dies schon früh bei Arrow (1962: 622-5).

Die Bedeutung staatlicher Fördermaßnahmen veranschaulicht Abbildung 1: Sie zeigt, dass staatliche Fördermaßnahmen für Forschung, Entwicklung und Innovation (Research, Development and Innovation, R\&D\&I) im Jahr 2013 mit 14,4 Prozent der Nicht-KrisenMaßnahmen in Europa und 18,9 Prozent der Nicht-Krisen-Maßnahmen in Deutschland einen relevanten Anteil an den staatlichen Hilfsmaßnahmen ausmachen. 


\section{Abbildung 1: Übersicht staatlicher Hilfsmaßnahmen in Europa (Non-Crisis-Aid) im Jahr 2013}

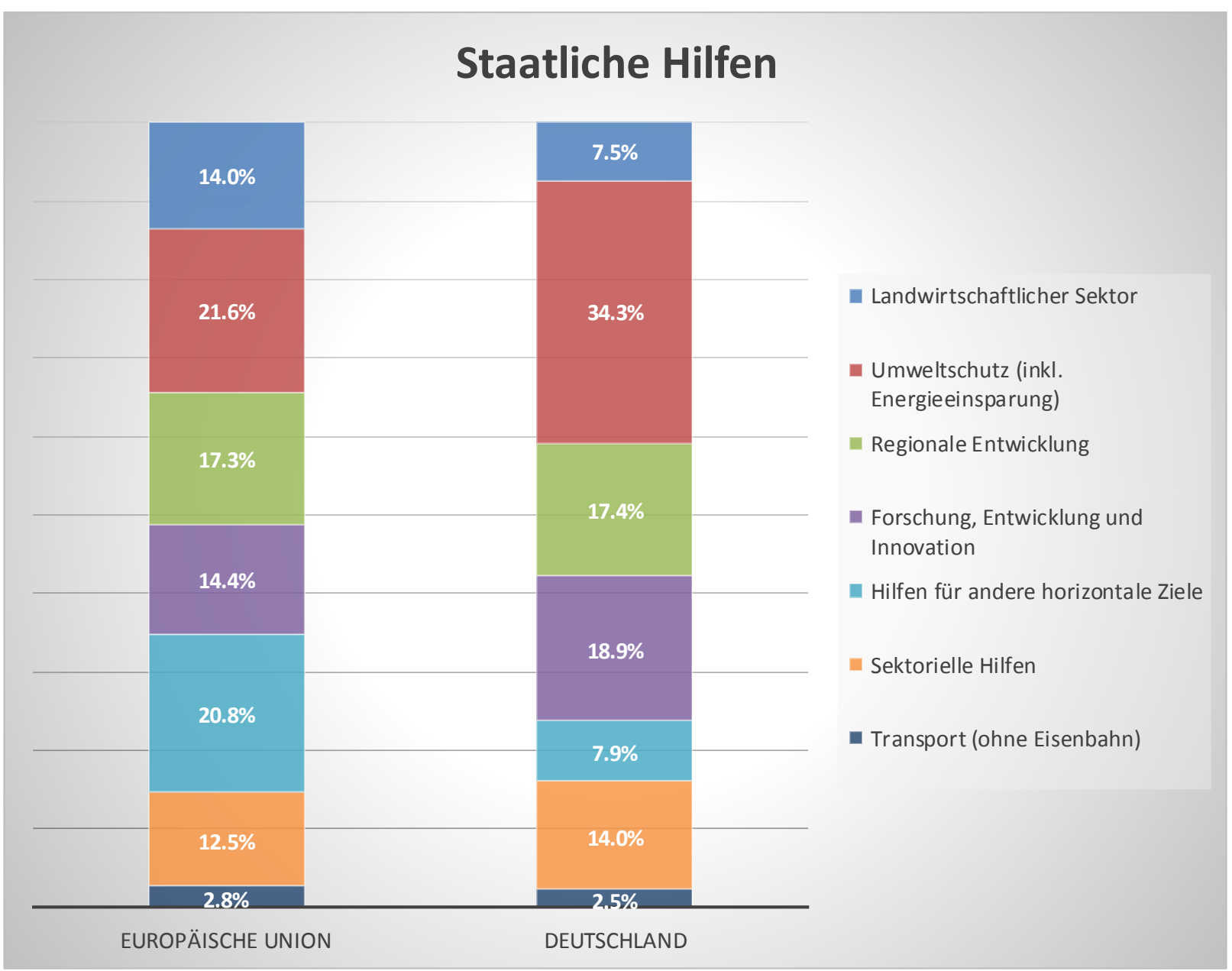

Daten: European Commission (2014b); Anmerkungen: Eigene Berechnungen; durch Rundung der Daten kommt es zu Summen über $100 \%$.

Hierbei sind Programme zu unterscheiden, die eine spezielle Technologie - wie die Nanotechnologie oder den Einsatz regenerativer Energien - unterstützen und Programme, die breiter Innovationen fördern sollen. Anhand der verwendeten Datensätze wird mit Ausnahme von Fallstudien meist jedoch beides synchron analysiert.

Die Möglichkeiten zur Analyse der Zielerreichung verschiedener Programme sind hierbei vielfältig: Teilweise werden anhand von Fallstudien einzelne Programme untersucht oder verglichen, teilweise werden die Charakteristika der geförderten Firmen untersucht und teilweise werden Effektivität und die Gefahr des Crowding-Out durch staatliche Förderung evaluiert.

Mit Blick auf die Gefahr des Crowding-Out, also der Verdrängung privater Innovationsaktivitäten durch staatliche Förderung, ist in der Literatur belegt, dass ein vollständiges Crowding-Out 
nahezu sicher ausgeschlossen werden kann. ${ }^{1}$ Trotz schwankender Werte kann so in Deutschland eine Additionalität staatlicher Innovationsförderung und die Stimulierung weiterer privater Aktivitäten ebenso belegt werden wie in Belgien, Frankreich und Irland. ${ }^{2}$

Bei den geförderten Unternehmen ergeben sich mit Blick auf ihre Charakteristika jedoch deutliche Unterschiede: Nach bisherigen Studien werden im Besonderen kleine und mittlere Unternehmen eher schlecht erreicht. Stattdessen zeigen Studien einen Effekt auf, dass Förderinstitutionen eher die Projekte aussuchen, die von vornherein größere Erfolgsaussichten haben (Cantner und Kösters 2012: 932-3).

Die Effektivität staatlicher Fördermaßnahmen lässt sich über die verschiedenen Fallstudien, aber auch über einige empirische Studien herleiten: Hier zeigt sich - über den Aspekt des Crowding-Outs hinaus - ein gemischtes Bild mit Blick auf die Effektivität staatlicher Förderung. Die Erhöhung der Wettbewerbsfähigkeit durch staatliche Innovationsförderung lässt sich in einzelnen Fällen belegen, allerdings gibt es auch andere Studien, die weniger klare Effekte aufzeigen und in denen die Wirkung von Innovationsaktivitäten auf die Wettbewerbsfähigkeit sogar kaum feststellbar ist (vgl. Hussinger 2008: 743; vgl. Asplund, Hrsg. 2000).

\subsection{Föderalismus und staatliche Innovationsförderung}

Unterschiedliche Teilbereiche der Föderalismustheorie, die in der Ökonomie vor allem mit Tiebout (1956) und Oates (1972) erstarkt ist, betonen verschiedene Gründe der Vorteilhaftigkeit föderaler Strukturen. Durch dezentrale föderale Strukturen kann aus verschiedenen Gründen eine Begrenzung und höhere Zielerreichung staatlichen Handelns abgeleitet werden.

So erhöhen sich die Kontrollmöglichkeiten und die Kenntnisse der Bürger von Entscheidungen in einer föderalen Struktur. Entsprechend der Theorie ergibt sich durch die größere räumliche Nähe und die engere Zuständigkeit in kleineren Wahlkreisen auf der regionalen Ebene ein transparenteres Verfahren, bei dem einzelne politische Akteure stärker mit ihren Entscheidungen verbunden werden und für diese und deren Folgen im Rahmen kommender Wahlen besser haftbar gemacht werden können (vgl. Oates 2005: 359).

Durch diese Kontrollmöglichkeit, aber auch durch die räumliche Nähe, ergibt sich eine stärkere Fokussierung auf die Präferenzen in der jeweiligen Region. Einerseits haben politische Akteure

\footnotetext{
${ }^{1}$ Es gibt lediglich eine Studie von Wallsten (2000), die ein komplettes Crowding-Out für ein Förderprogramm in den USA feststellt. Diverse andere Studien kommen jedoch sowohl generell in den USA als auch in anderen Ländern zu anderen Ergebnissen.

2 Czarnitzki und Fier (2002: 17-8) sowie Hussinger (2008: 743) kommen zu diesem Ergebnis für Deutschland, Aerts und Czarnitzki (2004: 16) für Belgien, Duguet (2004: 271-2) für Frankreich und Görg und Strobl (2007: 231) für kleine und mittlere Förderungen in Irland.
} 
einen Anreiz, sich stärker an den Präferenzen zu orientieren, andererseits sind diese Präferenzen in einem kleineren Gebiet auch homogener als in einem größeren nationalen Gebiet und damit besser umsetzbar (vgl. Neumann 1971: 500; vgl. Erlei et al. 2007: 440-1).

Daneben erhöht sich die Erreichbarkeit für die einzelnen Wirtschaftssubjekte, da Ansprechpartner nicht nur in einer weiter entfernten Hauptstadt, sondern dezentral direkt in den Regionen vorhanden sind. Für das einzelne Unternehmen reduziert das etwaige Transaktionskosten.

Negative Aspekte der Dezentralität in föderalen Strukturen sind vor allem die Verluste von Skalenerträgen durch den Verlust von Synergien sowie notwendige Koordinierungsmaßnahmen (vgl. Erlei et al. 2007: 442; vgl. Konings und Torfs 2011: 39).

Durch die Notwendigkeit zusätzlicher Verwaltungsstrukturen ähnlicher Programme auf den unterschiedlichen Ebenen besteht die Gefahr zusätzlicher Bürokratie. Eine einfache Struktur auf der Ebene eines Zentralstaates kann hingegen diese Bürokratien vermeiden und Synergieeffekte durch Skalenerträge nutzen.

Weiterhin besteht zwischen den verschiedenen politischen Akteuren ein erhöhter Koordinierungsaufwand, der vermeiden soll, dass Programme verschiedener Ebenen nicht zueinander passen oder gegenläufige Ziele verfolgen. Die Transaktionskosten für den Staat durch die Koordinierung steigen demnach.

Auf dem Feld der staatlichen Innovationsförderung bedeutet dies einerseits, dass in einem zentralistischen System eine höhere Effektivität und Effizienz der Förderung zu erwarten ist, gleichzeitig die regionalen Besonderheiten und die Bedürfnisse der Unternehmen vor Ort weniger im Mittelpunkt stehen. Föderale Systeme andererseits richten sich stärker auf regionale Besonderheiten und die Bedürfnisse vor Ort aus, aber größere Verwaltungsstrukturen begünstigen hierbei Verluste bei der Effizienz und Effektivität.

Mit Blick auf unterschiedliche politische Systeme in Europa lassen sich aus beiden Argumenten unterschiedliche Erkenntnisse ziehen: Während Deutschland und Österreich als föderale Nationen auch in der Innovationsförderung sowohl auf Zuständigkeiten auf regionaler als auch auf gesamtstaatlicher Ebene setzen, hat die Schweiz als föderale Nation ihre Innovationsförderung auf zentralstaatlicher Ebene gebündelt. Ebenso lassen sich in zentralistischen Ländern unterschiedliche Tendenzen feststellen: Während in den vergangenen Jahren skandinavische Länder ergänzende regionale Programme stark ausgebaut haben, haben die kleineren baltischen Staaten dies in weitaus geringerem Maße getan (Vitola 2014: 2). 
Eine genauere Analyse der Innovationsförderung in der Bundesrepublik Deutschland ergibt, dass 15 der 16 Bundesländer allgemeine - nicht technologiespezifische - Programme zur Innovationsförderung auflegen. ${ }^{3}$

Weiterhin bieten alle deutschen Bundesländer Innovationsförderprogramme für spezielle Technologien an.

Entsprechend der Theorie des Föderalismus sollten beide Arten von regionalen Programmen einen Schwerpunkt auf eine stärkere Orientierung an den regionalen Besonderheiten, komparativen Vorteilen und Bedürfnissen der Unternehmen vor Ort legen. Dies lässt sich einerseits belegen, wenn ein produzierendes Bundesland wie Bayern spezielle Förderprogramme z.B. für neue Werkstoffe auflegt. Andererseits lässt sich bei bundesweit verbreiteten Programmen zur Umwelttechnik oder Nanotechnologie auch kritisch hinterfragen, ob hierbei wirklich in so vielen Bundesländern komparative Vorteile herrschen. Wenn - wie beim Thema Umwelttechnik der Fall - in allen Bundesländern eine Förderung erfolgt, könnte vielmehr eine grundsätzliche Ansiedlung auf der Bundesebene sinnvoller sein. Von Relevanz in Deutschland sind auch die besonderen Strukturen in Ostdeutschland. Da in den ostdeutschen Bundesländern erheblich weniger Großunternehmen (GU) ihre Forschungsabteilungen haben, übernehmen hier andere Institutionen, wie z.B. Forschungszentren, stärker Schnittstellenfunktionen, die in Westdeutschland durch Großunternehmen wahrgenommen werden (Belitz et al. 2010: 4).

Mit Blick auf die verschiedenen staatlichen Ebenen der Förderung sind bisher in Deutschland keine unabhängigen Untersuchungen vorgenommen worden. Im Rahmen der Evaluation unterschiedlicher Programme werden zwar auch jeweils andere Programme untersucht, aber die Zielgruppen und die Wirkungen der Programme der unterschiedlichen Ebenen wurden hierbei nicht im Detail betrachtet. Auch im europäischen Ausland sind solche Betrachtungen selten. Vitola (2014) beleuchtet die Ausgestaltung von Programmen unterschiedlicher politischer Ebenen für den Ostseeraum - in diesem Fall die skandinavischen Länder sowie die drei baltischen Staaten - allerdings nur theoretisch. Empirisch untersuchen Busom und FernándezRibas (2007) und Fernández-Ribas (2009) die Wirkung der Programme unterschiedlicher Ebenen für Katalonien in Spanien. Diese Studien dienen auch als Referenzwert für die Variablenauswahl in dieser Dissertation - sofern entsprechende Daten verfügbar waren und zielführend erschienen.

\footnotetext{
3 „Wie [...] aufgezeigt wird, gibt es in fast allen Bundesländern (Ausnahme: Baden-Württemberg) mindestens ein Förderprogramm des Landes, das einzelbetriebliche FuE-Projekte und/oder FuE-Verbund- beziehungsweise Kooperationsprojekte ohne Begrenzung auf ein spezielles Technologiefeld fördert.“ Kulicke et al. (2010: 79)
} 


\subsection{Kleine und mittlere Unternehmen und staatliche Innovationsförderung}

Kleine und mittlere Unternehmen werden häufig als die Triebfedern der wirtschaftlichen Entwicklung und der Schaffung von Arbeitsplätzen bezeichnet. So betont die deutsche Bundeskanzlerin Angela Merkel in der gleichen Wortwahl wie ihr Vorgänger Gerhard Schröder die Bedeutung der mittelständischen Wirtschaft. ${ }^{4}$ Gleichzeitig sind kleine und mittlere Unternehmen mit besonderen Herausforderungen konfrontiert. $\mathrm{Zu}$ beachten ist in diesem Zusammenhang die Definition kleiner und mittlerer Unternehmen. In dieser Dissertation wird ausschließlich die Definition der Europäischen Union verwendet. ${ }^{5}$ Frühere, weitergehende Definitionen aus Deutschland werden nicht berücksichtigt. ${ }^{6}$

Die folgenden Abbildungen 2 und 3 zeigen die volkswirtschaftliche Bedeutung anhand des Anteils aller Unternehmen, des Anteils der Mitarbeiterzahl und des Anteils an der Wertschöpfung. ${ }^{7}$

4 Sie bezeichnen beide mittelständische Unternehmen als das „Rückgrat“ der Wirtschaft, z.B. DeutscheHandwerksZeitung (2010) und Kolhoff (2002).

5 Entsprechend der Definition der Europäischen Union sind Kleinstunternehmen Unternehmen mit weniger als 10 Mitarbeitern, bis zu 2 Millionen Euro Umsatz oder maximal ebenso hoher Bilanzsumme. Kleinunternehmen haben definitorisch weniger als 50 Mitarbeiter und bis zu 10 Millionen Euro Umsatz oder Bilanzsumme. Mittlere Unternehmen besitzen unter 250 Mitarbeiter und bis zu 50 Millionen Euro Umsatz oder bis zu 43 Millionen Euro Bilanzsumme. Alle Unternehmen mit größerer Mitarbeiterzahl, größerem Umsatz oder größerer Bilanzsumme sind dementsprechend im Sinne dieser Definition Großunternehmen.

6 Das IfM Bonn würde die Mitarbeiterzahl unter 500 Mitarbeiter mit Umsatz unter 50 Millionen Euro als mittleres Unternehmen ansehen. In der Öffentlichkeit werden teils auch erheblich größere Unternehmen noch als sogenannte Mittelständler bezeichnet.

${ }^{7}$ Da die Europäische Union neben Mitarbeiterzahl und Zahl der Unternehmen die Wertschöpfung darstellt, während in Deutschland üblicherweise der Umsatz ausgewiesen wird, wird hier auch die Wertschöpfung verwendet. Diese bezieht sich auf den Umsatz abzüglich von Vorleistungen. Somit wären die Umsatzzahlen höher. Bei der vorliegenden Darstellung der Anteile wären die Anteile der Großunternehmen an den Umsätzen ebenfalls höher. 
Abbildung 2: Bedeutung von KMU in Europa im Jahr 2013

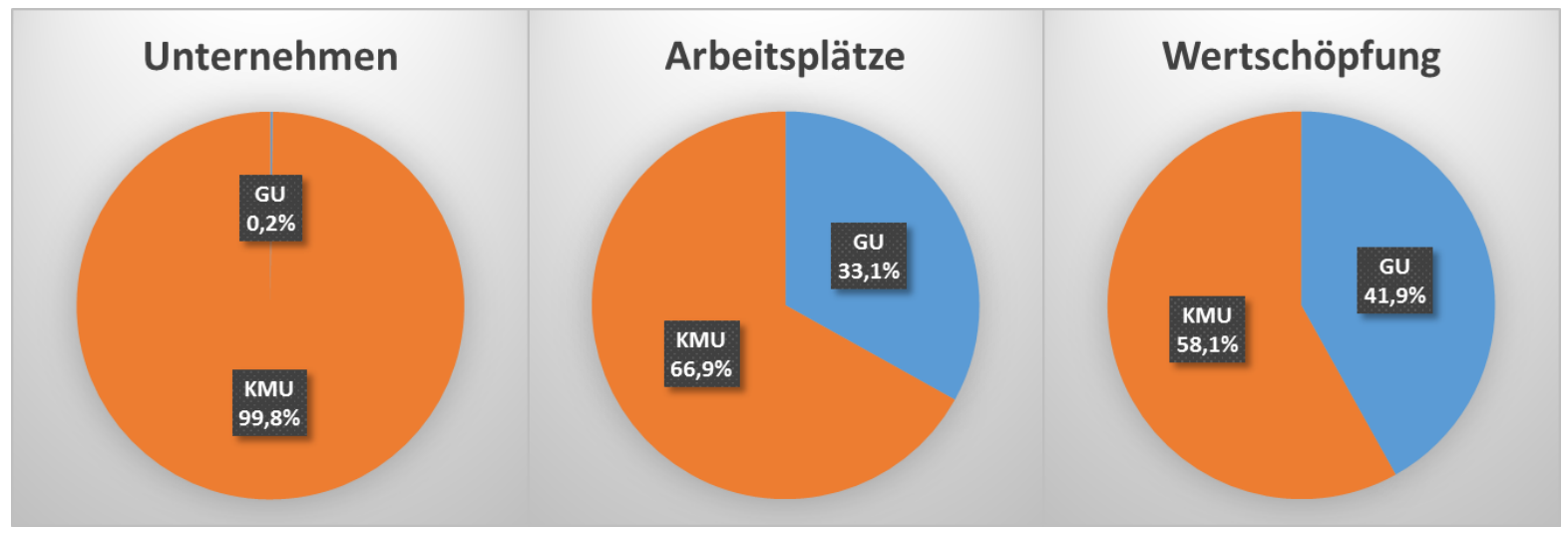

Daten: European Commission (2014a); eigene Darstellung.

\section{Abbildung 3: Bedeutung von KMU in Deutschland im Jahr 2013}

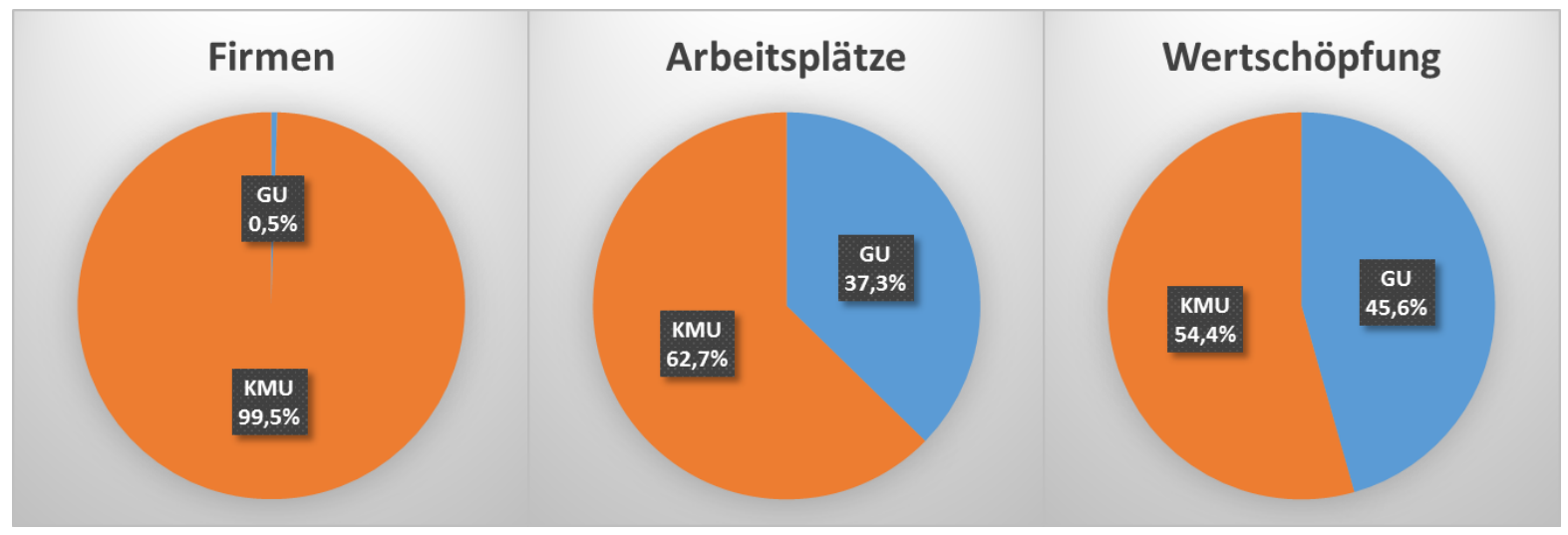

Daten: European Commission (2014a); eigene Darstellung.

Mit Blick auf die Bedeutung von KMU für die Innovationstätigkeit zeigen sich erhebliche Unterschiede in der Literatur. Während Audretsch (2001: 6) die Bedeutung kleinerer und mittlerer Unternehmen als Treiber des innovativen Fortschritts aufgrund ihrer Kreativität hervorhebt, kommt Schumpeter (1911/1934: 115-6) und noch klarer in Schumpeter (1942/2008: 106) aufgrund der Bedeutung von Skalenerträgen durch zentrale Forschungs- und Entwicklungsabteilungen zur Erkenntnis einer größeren innovativen Bedeutung von Großunternehmen. Außerhalb der Theorie lassen sich Beispiele für beide Argumentationsstränge finden. Während in der chemischen Industrie aufgrund hoher Kosten vor allem Großunternehmen aktiv sind, wäre die Entwicklung auf dem Sektor der Informations- und Telekommunikationstechnologien wohl kaum ohne kleine und mittlere Unternehmen in der gleichen Geschwindigkeit fortgeschritten.

Unstreitig ist aber, dass kleine und mittlere Unternehmen sich mit höheren Barrieren zur Innovationstätigkeit und anderen Problemen bei dieser konfrontiert sehen. So betrifft das 
Problem der Unsicherheit KMU stärker, da diese generell stärker auf Marktunsicherheiten reagieren (Czarnitzki und Toole 2008: 10) und weniger Möglichkeiten zur Risikostreuung haben (Levine 1997: 694). Ein KMU hat weniger Möglichkeiten, parallel mehrere Forschungsprojekte durchzuführen und so im Falle des Nicht-Erfolgs diesen einfach durch ein anderes Projekt zu kompensieren. Gleichzeitig zeigt sich, dass KMU eine höhere Produktivität ihrer Innovationstätigkeit aufweisen können. ${ }^{8}$ Zugleich sind kleinere Unternehmen auch mit anderen Problemen bei der Ausschließung von Mitbewerbern konfrontiert, da sie, wie Thomä und Bizer (2013: 46) belegen andere Formen des Schutzes ihres intellektuellen Eigentums wählen und nicht-kodifiziertes Wissen stärker nutzen. Von Bedeutung in diesem Zusammenhang ist, dass empirische Studien eine Tendenz zur Unterschätzung der Bedeutung von Innovationen kleiner und mittlerer Unternehmen haben, da dort die formalen Strukturen der Innovationstätigkeit weniger ausgeprägt sind und diese Strukturen häufig zur Bewertung herangezogen werden (Thomä 2012: 12-3).

Diese Argumente führen dazu, dass - gut begründet - nahezu alle Förderprogramme auf allen politischen Ebenen besonders auf kleine und mittlere Unternehmen zielen und deren Innovationstätigkeit fördern möchten. Positive Effekte einer solchen Zielsetzung sind außerhalb Europas belegt. So stellt Lach (2002: 389) für Israel fest, dass die Förderung kleinerer Unternehmen dort eine höhere Wirkung als bei Großunternehmen erzielt.

Gleichzeitig sind aber Studien, die speziell die Zielerreichung in Deutschland und Europa untersuchen, selten und meist nur in der Evaluation eines einzelnen Programmes zu finden (vgl. Kulicke et al. 2010; vgl. Mertins 2009). Eine übergreifende Analyse der Förderlandschaft erscheint aber - gerade mit Blick auf die vorher skizzierte Problemstellung der unterschiedlichen Förderebenen - durchaus angebracht.

\section{3 Überblick über die Einzelbeiträge}

Ausgehend von der Literaturübersicht werden in den Einzelbeiträgen vor allem zwei Facetten intensiver beleuchtet. Die Charakteristika geförderter Unternehmen mit Blick auf die unterschiedlichen Ebenen der Förderung werden im zweiten und dritten Kapitel in den Mittelpunkt gestellt. Im vierten Kapitel wird - unabhängig von den Förderebenen - die Effektivität der Förderung untersucht. Dies steht auch im Kontext einer ersten Effektivitätsuntersuchung am Rande des zweiten Kapitels. Anschließend ergeben sich im fünften Kapitel Politikimplikationen aus den empirischen Erkenntnissen.

\footnotetext{
8 Eine umfassende Literaturübersicht zu dieser Fragestellung bietet Cohen (2010) sowie der gleiche Autor in früheren Beiträgen wie Cohen und Levin (1989).
} 
Tabelle 1: Grafische Übersicht über die Einzelbeiträge

\begin{tabular}{|c|c|c|c|c|}
\hline Themenschwerpunkt & $\begin{array}{l}\text { Unternehmens- } \\
\text { charakteristika }\end{array}$ & $\begin{array}{l}\text { Unternehmens- } \\
\text { charakteristika }\end{array}$ & Effektivität & $\begin{array}{l}\text { Politik- } \\
\text { implikationen }\end{array}$ \\
\hline Kapitel & 2 & 3 & 4 & 5 \\
\hline Titel & $\begin{array}{l}\text { No gains of } \\
\text { federalism in } \\
\text { innovation } \\
\text { support? } \\
\text { The case of } \\
\text { Germany }\end{array}$ & $\begin{array}{l}\text { Federalism and } \\
\text { innovation } \\
\text { support for small } \\
\text { and medium- } \\
\text { sized enterprises } \\
\text { Empirical } \\
\text { evidence in } \\
\text { Europe }\end{array}$ & $\begin{array}{l}\text { Effectiveness of } \\
\text { public innovation } \\
\text { support in } \\
\text { Europe } \\
\text { Does public } \\
\text { support foster } \\
\text { turnover, } \\
\text { employment and } \\
\text { labour } \\
\text { productivity? }\end{array}$ & $\begin{array}{l}\text { Föderalismus in } \\
\text { der staatlichen } \\
\text { Innovations- } \\
\text { förderung: } \\
\text { Wirkung föderaler } \\
\text { Strukturen und ihre } \\
\text { Politikimplikationen }\end{array}$ \\
\hline Gebiet & Deutschland & $\begin{array}{l}\text { Europäische } \\
\text { Union }\end{array}$ & $\begin{array}{l}\text { Europäische } \\
\text { Union }\end{array}$ & $\begin{array}{l}\text { Deutschland, } \\
\text { Europäische Union }\end{array}$ \\
\hline Datenbasis & $\begin{array}{l}\text { Mannheimer } \\
\text { Innovationspanel } \\
\text { (MIP), } 2007\end{array}$ & $\begin{array}{l}\text { Community } \\
\text { Innovation } \\
\text { Survey (CIS), } \\
2008\end{array}$ & $\begin{array}{l}\text { Community } \\
\text { Innovation } \\
\text { Survey (CIS), } \\
2008\end{array}$ & $\begin{array}{l}\text { Daten der drei } \\
\text { vorangegangenen } \\
\text { Kapitel }\end{array}$ \\
\hline Untersuchungsgruppe & $\begin{array}{l}\text { Innovative } \\
\text { Unternehmen in } \\
\text { Deutschland }\end{array}$ & $\begin{array}{l}\text { Innovative } \\
\text { Unternehmen in } \\
16 \\
\text { Mitgliedsstaaten } \\
\text { der EU }\end{array}$ & $\begin{array}{l}\text { Innovative } \\
\text { Unternehmen in } \\
15 \\
\text { Mitgliedsstaaten } \\
\text { der EU }\end{array}$ & $\begin{array}{l}\text { Untersuchungs- } \\
\text { gruppen der drei } \\
\text { vorangegangenen } \\
\text { Kapitel }\end{array}$ \\
\hline Statistische Methoden & Logit-Regression & $\begin{array}{l}\text { Nearest } \\
\text { Neighbour } \\
\text { Matching mit } \\
\text { Probit- } \\
\text { Regression als } \\
\text { struktureller } \\
\text { Gleichung }\end{array}$ & $\begin{array}{l}\text { Nearest } \\
\text { Neighbour } \\
\text { Matching mit } \\
\text { Probit- } \\
\text { Regression als } \\
\text { struktureller } \\
\text { Gleichung; } \\
\text { gewichtete OLS- } \\
\text { Regression }\end{array}$ & $\begin{array}{l}\text { Methoden der drei } \\
\text { vorangegangenen } \\
\text { Kapitel }\end{array}$ \\
\hline
\end{tabular}

Basierend auf ähnlicher Übersicht in Thomä (2012: 18). 
Die verwendeten Methoden richten sich stark nach den Zielen und den zugrunde liegenden Daten der jeweiligen Erhebung: Bei der Untersuchung der Unternehmenscharakteristika für die binär-kodierten Variablen der staatlichen Unterstützung werden logistische Regressionen entsprechend der Zahl der Beobachtungen als Logit oder Probit geschätzt, sowie im Falle der Europäischen Union mit Propensity Score Matching-Methoden zur Korrektur für Selektionsprobleme kombiniert. Im Rahmen der Effektivitätsanalyse werden für kontinuierlich kodierte Variablen Ordinary Least Squares Regressionen verwendet. ${ }^{9}$

\section{Zusammenfassung der Einzelbeiträge, Hintergründe und Ergebnisse}

\subsection{No gains of federalism in innovation support? The case of Germany}

Aufbauend auf zwei ähnlichen Untersuchungen in Spanien (Busom und Fernández-Ribas 2007) und Katalonien (Fernández-Ribas 2009), die unterschiedliche Zielgruppen für die Förderung durch unterschiedliche politische Ebenen feststellen und dabei zu dem Ergebnis kommen, dass regionale Programme insbesondere Unternehmen mit Hürden zur Innovation - wie KMU unterstützen, analysiert der erste Einzelbeitrag im zweiten Kapitel die Situation in Deutschland. Anhand von Daten des Mannheimer Innovationspanel (MIP) des Zentrums für Europäische Wirtschaftsforschung (ZEW) aus dem Jahr 2007 werden die Charakteristika geförderter Unternehmen der jeweiligen Programmebenen untersucht. Daneben werden in weiteren Untersuchungen die Auswirkungen mit Blick auf Effektivität der Förderung - gemessen an der Entwicklung von Umsatz und Umsatzrendite - analysiert. Ferner wird mittels der Kombination der MIP-Datenwellen 2005 und 2007 auch der Einfluss vergangener Förderung geprüft. Hierbei ist zu beachten, dass die Anzahl der Beobachtungen hier stark eingeschränkt ist, da es sich beim MIP um ein sogenanntes unbalanced panel handelt, bei dem nicht immer die gleichen Unternehmen teilnehmen.

Diese drei Untersuchungen erfolgen mittels binärer Regression und werden aufgrund der teils niedrigen Beobachtungszahlen als Logit-Regressionen durchgeführt.

Für die zentrale Analyse der Firmencharakteristika wurden dabei 1.259 Beobachtungen, die alle gewählten Variablen angegeben haben, herangezogen. ${ }^{10}$ Von diesen untersuchten innovativen Unternehmen haben 18,7 Prozent regionale Förderung erhalten. 27,1 Prozent erhielten

\footnotetext{
${ }^{9}$ Als Standardwerk für die verschiedenen Methoden und dementsprechend relevant für eine Übersicht ist Wooldridge (2010) anzusehen. Deutschsprachig gibt Müller (2012) einen guten Überblick über die Methode.

${ }^{10}$ Eine Datenwelle des MIP umfasst insgesamt rund 6.000 befragte Unternehmen.
} 
Förderung durch die nationale Ebene in Deutschland und 11,0 Prozent haben europäische Förderung erhalten. Zu beachten ist hierbei, dass entsprechend der Auskunft des ZEW die Teile der europäischen Förderung, die über die deutschen Bundesländer verteilt werden (also insbesondere die Mittel aus dem Europäischen Fonds für Regionale Entwicklung, EFRE), von den meisten geförderten Unternehmen als regionale Förderung angesehen werden. Mit Blick auf die folgenden Kapitel ist außerdem anzumerken, dass im MIP eine größere Anzahl an untersuchbaren Variablen für die Unternehmen als auf europäischer Ebene vorliegt.

Die Ergebnisse der Regressionen zeigen, dass die Charakteristika der geförderten Unternehmen zwischen den Programmebenen deutlich variieren: Während einzelne Variablen, wie die Höhe des zur Verfügung stehenden Budgets für Forschung und Entwicklung, auf allen Ebenen relevante Effekte zeigen, haben Merkmale wie der Marktanteil (positiv) oder die überregionale Marktausrichtung (negativ) nur auf europäischer Ebene Auswirkungen, andere Merkmale wie der Grad an Qualitätswettbewerb (positiv) nur auf nationaler Ebene. Bei der regionalen Ebene erreichen nur wenige Variablen Signifikanz. Gleichzeitig wird aber deutlich, dass während die Variable für kleine und mittlere Unternehmen auf europäischer Ebene signifikant negativ ist und auf nationaler Ebene einen negativ, aber nicht signifikanten Koeffizienten aufweist. Der Koeffizient auf der regionalen Ebene ist positiv, obgleich nicht signifikant. Regionale Besonderheiten zeigen sich insbesondere für die ostdeutschen Bundesländer mit hoch signifikanten und positiven Koeffizienten für regionale und nationale Förderung und einem negativen und etwas schwächer signifikanten Koeffizienten auf europäischer Ebene.

Mit Blick auf Firmencharakteristika zeigt sich, dass die dreigeteilte Förderstruktur in Deutschland ein breiteres Spektrum an Unternehmen anspricht, auch wenn der Effekt für Unternehmen mit Barrieren zur Innovationstätigkeit weniger klar als in den Studien in Spanien beziehungsweise Katalonien ist. Regionale Unterschiede bestehen insbesondere zwischen Unternehmen in Ostund Westdeutschland, aber auch zwischen Geber- und Nehmerländern im Länderfinanzausgleich. Mit Blick auf Marktausrichtung zeigt nur die europäische Ebene eine positive Wirkung regionaler Marktausrichtungen, was durchaus überraschend ist.

Trotz dieser unterschiedlichen Eigenschaften der Unternehmen gibt es doch mit den Ausgaben für Forschung und Entwicklung und den Interaktionsvariablen für unterschiedliche Förderung einen gemeinsamen Kern ähnlicher Eigenschaften für alle Förderebenen, wie er bereits in Becker (2012: 62) sichtbar wurde. Gleichzeitig begünstigen frühere Förderungen auch den erneuten Erhalt von staatlicher Förderung.

Die Analyse der Effektivität der staatlichen Förderung nach Ebenen zeigt, dass ausschließlich die nationale Ebene mit Blick auf eine positive Entwicklung von Umsatz und Umsatzrendite die 
angestrebten Effekte erzielt. Die regionale Förderung zeigt hier einen signifikanten und positiven Koeffizienten für einen Rückgang des Umsatzes, während die europäische Förderung einen signifikanten und negativen Koeffizienten für den Anstieg der Umsatzrentabilität aufzeigt. Der Großteil der Untersuchungen für beide Förderebenen bleibt jedoch insignifikant. Zu beachten ist hierbei, dass die entsprechenden Variablen nur einen sehr geringen Einfluss auf die jeweiligen Unternehmenskennzahlen haben.

Zusammenfassend kann für das zweite Kapitel also festgehalten werden, dass föderale Strukturen in Deutschland zu einer größeren Vielfalt an geförderten Unternehmen beitragen, gleichzeitig aber nur die nationale Ebene ihre Ziele mit Blick auf eine erhöhte Wettbewerbsfähigkeit erreicht.

\subsection{Federalism and innovation support for small and medium-sized enterprises: Empirical evidence in Europe}

Das dritte Kapitel greift die Studie des vorherigen Kapitels zu Deutschland auf, ebenso wie ähnliche Arbeiten z.B. von Blanes und Busom (2004) für andere europäische Länder.

Weiterhin anhand von Mikrodaten, diesmal aber insbesondere mit Blick auf die Auswirkungen föderaler Strukturen, werden Daten aus sechzehn verschiedenen Mitgliedsstaaten der Europäischen Union untersucht.

Als Datengrundlage dient die Community Innovation Survey (CIS) von Eurostat. Durch harmonisierte Abfragen in den einzelnen Mitgliedsstaaten soll sie eine einheitliche Datengrundlage für die Europäische Union schaffen. Die dabei entstehenden Probleme werden im Kapitel ebenfalls beleuchtet. Ähnlich wie beim MIP handelt es sich um ein unbalanced panel, sodass in diesem Fall von der Nutzung als Panel abgesehen wird und Querschnittsdaten verwendet werden. Aufgrund der unterschiedlichen Datenqualität wurde die Anzahl an untersuchten Ländern auf sechzehn reduziert, davon nur ein föderales Land, drei semiföderale Länder und zwölf zentralistische Staaten.

Verglichen mit dem vorherigen Kapitel ergeben sich in Europa erheblich niedrigere Förderquoten: So erhalten 8,0 Prozent der Unternehmen regionale Förderung, 9,8 Prozent nationale und 4,0 Prozent europäische Förderung. Dies kann zumindest teilweise auch damit erklärt werden, dass in einigen Ländern der Europäischen Union die Teilnahme an der Landeserhebung der CIS obligatorisch ist. Dadurch nehmen erheblich mehr nur auf niedrigerem Niveau innovationstätige Unternehmen teil.

Um diesem und anderen Selektionsproblemen, wie dem sogenannten „cream skimming“ (Radicic und Pugh 2013: 1), zu begegnen, wird ein Propensity Score Matching (als Nearest Neighbour Matching) durchgeführt. Zur Analyse der Einflussfaktoren auf den Erhalt der 
Förderung dient hierbei wiederum eine binäre Regression als strukturelle Gleichung. Aufgrund der höheren Zahl von 77.779 Beobachtungen und dem Zusammenspiel mit dem MatchingProzess wird jedoch in diesem Kapitel eine Probit-Regression angewendet.

Fokussiert auf den Bezug zu föderalen Strukturen werden dabei kleine und mittlere Unternehmen aus föderalen, semiföderalen und zentralistischen Mitgliedsstaaten jeweils separat als erklärende Variablen ausgewiesen. Daneben werden ähnlich wie im vorherigen Kapitel weitere Firmencharakteristika untersucht. $\mathrm{Zu}$ beachten ist hierbei, dass ein Teil der Untersuchung nur in separaten Länderregressionen möglich ist, da einige Variablen nicht in allen Ländern vorliegen.

Im Ergebnis lässt sich festhalten, dass ein positiver Aspekt föderaler und semiföderaler Strukturen insbesondere bei regionaler Förderung und Kombinationen von regionaler und überregionaler Förderung sichtbar wird, sodass die Koeffizienten für KMU in diesen Ländern positive und häufig signifikante Effekte aufzeigen. Mit Blick auf die nationale und supranationale Förderung setzt sich dieser Effekt jedoch nicht fort. Hier zeigen, verglichen mit Großunternehmen, die semiföderalen und föderalen Koeffizienten ebenfalls negative Effekte.

Kleine und mittlere Unternehmen haben andererseits in zentralistischen Ländern mit Ausnahme der europäischen Ebene immer einen negativen Koeffizienten verglichen mit Großunternehmen, auch wenn dieser nicht immer signifikant ist.

Die Koeffizienten zur Förderung von regelmäßig innovativtätigen Unternehmen zeigen, dass diese auf allen Ebenen eine höhere Wahrscheinlichkeit der Förderung aufweisen, was sich auch in den Länderregressionen bei den Koeffizienten für die Summe der investierten Fördermittel bestätigt. Ausländische Firmen zeigen indes negative Koeffizienten für alle Förderebenen.

Einschränkend ist festzuhalten, dass der Grad der Erklärung durch das strukturelle Modell zwar durchaus ähnlich wie im zweiten Kapitel ist, allerdings die Average Treatment Effects of the Treated (ATTs) des Propensity Score Matching im Gegensatz zu Fernández-Ribas (2009: 464) keine Signifikanzen erreichen. Festzuhalten ist aber, dass bei 27 von 32 ATTs positive (aber insignifikante) Werte vorliegen.

Es kann zusammenfassend festgehalten werden, dass auch im europäischen Vergleich regionale Förderung Unternehmen mit Hürden zur Innovationstätigkeit, wie kleine und mittlere Unternehmen, besser erreicht, und somit wiederum zu einem breiteren Spektrum an geförderten Unternehmen beiträgt. Zu beachten ist hierbei, dass dieser Effekt starke Zusammenhänge mit dem politischen System aufzeigt, so dass föderale und semiföderale Staaten kleine und mittlere Unternehmen mit ihren regionalen Programmen besser erreichen. Gleichzeitig wird aber sichtbar, dass auf gesamteuropäischer Ebene zwar ein positiver, aber kein signifikanter Effekt der Förderung auf die Innovationstätigkeit von Unternehmen belegbar ist. 


\subsection{Effectiveness of public innovation support in Europe: Does public support foster turnover, employment and labour productivity?}

Das vierte Kapitel greift die Frage der Effektivität staatlicher Innovationsförderung wieder auf und überträgt sie auf die europäische Ebene. Ausgehend von der Feststellung von Cerulli (2010: 445), dass Innovationsbemühungen stärker als Mittel zum Zweck denn als Zweck selbst zu sehen sind und vielmehr die Erhöhung der Wettbewerbsfähigkeit von Unternehmen das eigentliche Ziel sei, wird die Frage der Wirkung von Innovationen, aber auch von staatlicher Innovationsförderung, untersucht.

Nach einer ersten Übersicht, welche Länder mit welchem Anteil ihrer Fördermaßnahmen staatliche Innovationsförderung durchführen, sind aus bisherigen Studien über die Effektivität verschiedene, teils unklare Ergebnisse belegt. Die Effektivität gilt deshalb in der Literatur als umstritten.

\section{Abbildung 4: Anteil der Innovationshilfen (zu generellen Hilfen) 2007-2012 in Europa}

\section{Durchschnitt des Anteils staatlicher Innovationshilfen nach EU-Mitgliedsland}

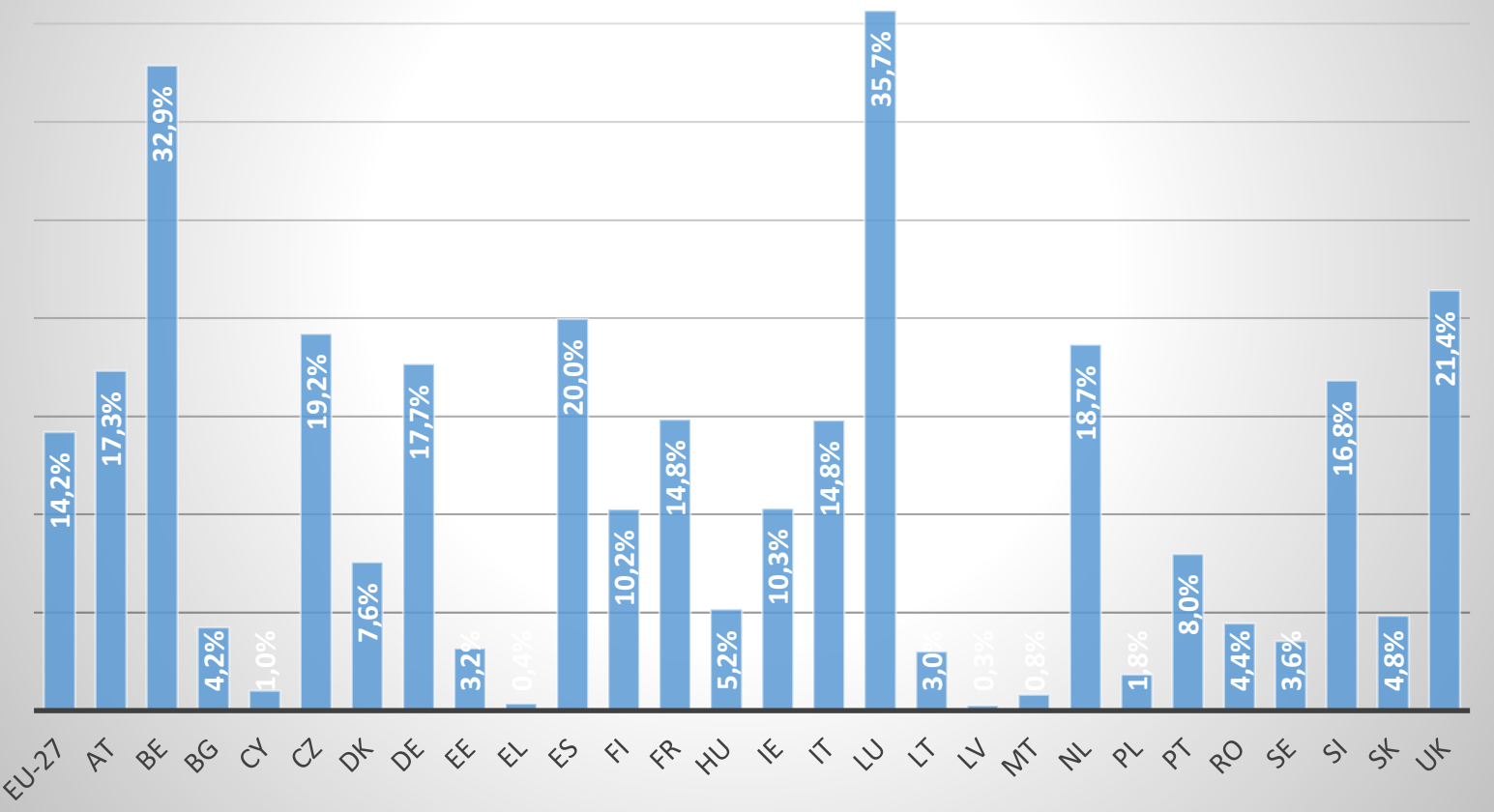

Daten: European Commission (2013); Anmerkungen: Eigene Berechnungen; Durchschnitt der Anteile der Jahre 2007-2012 der staatlichen Innovationshilfen relativ zu allen (Nicht-Krisen-)Hilfen, vgl. Kapitel 4. 
Diese Problematik aufgreifend sollen fünfzehn europäische Länder in Bezug auf die Effektivität ihrer Förderung untersucht werden. Datengrundlage bildet wiederum die Community Innovation Survey aus dem Jahr 2008. Als Maßgrößen für die Effektivität dienen die Entwicklung der Umsätze, die Entwicklung der Beschäftigtenzahl sowie die Entwicklung der Arbeitsproduktivität ${ }^{11}$ zwischen den Jahren 2006 und 2008. Die Variablenauswahl sorgt für eine Verringerung der Zahl der Beobachtungen auf 29.451 Beobachtungen.

Um Selektionsproblemen zu begegnen, wird erneut ein Nearest-Neighbour-Matching durchgeführt. Neben verkürzten Schätzungen mit den politischen Systemen als regionalen Dummy-Variablen werden in diesem Fall hierfür auch alternativ alle Länder als DummyVariablen integriert, um Ländereffekte untersuchen zu können. Daneben sollen die Einflussgrößen auf die Entwicklung der drei Maßgrößen mittels Regressionen untersucht werden. Da es sich bei innen um kontinuierliche Variablen handelt, werden hierfür Ordinary Least Squares (OLS-) Regressionen, allerdings gewichtet mit den Gewichten des Matchings, verwendet.

Die ATTs zeigen im Fall des Matchings mit Ländervariablen keinerlei Signifikanz, im Falle des Matchings mit politischen Systemen wird ein negativer Einfluss der Förderung auf Prozessinnovationen signifikant und ein positiver Einfluss auf Produktinnovationen sowie der Einfluss auf die Arbeitsproduktivität erreichen die Signifikanz knapp nicht. Die weiteren Effekte bleiben jedoch fern jeglicher Signifikanz. Die Wirkungsrichtung der nicht-signifikanten Effekte ist jedoch in den meisten Fällen positiv.

Im Zuge der OLS-Regressionen mit Ländervariablen zeigen sich erheblich unterschiedliche, aber teils hochsignifikante, Einflussgrößen je nach gewählter Maßgröße.

Lediglich das Firmencharakteristikum der Ausgaben für Forschungs- und Entwicklungstätigkeiten zeigt für alle drei Indikatoren der Wettbewerbsfähigkeit einen positiven und signifikanten Koeffizienten. Andere Charakteristika, wie die erhaltene Förderung, variieren: Der Erhalt staatlicher Förderung zeigt einen negativen und signifikanten Koeffizienten auf die Entwicklung des Umsatz, einen negativen Koeffizienten - allerdings ohne Signifikanz - auf die Entwicklung der Mitarbeiterzahl sowie einen positiven und signifikanten Koeffizienten für die Entwicklung der Arbeitsproduktivität. Bei der Untersuchung der Unternehmensgröße scheint sich eine generell negative Wettbewerbsposition von kleinen und mittleren Unternehmen abzuzeichnen, da alle drei Koeffizienten negativ sind, jedoch erreicht nur der Koeffizient in der Regression für die Umsatzentwicklung Signifikanz.

${ }^{11}$ Aufgrund der Datengrundlage nur ermittelbar als Umsatz pro Beschäftigtem. 
Bei den Länderfaktoren ergibt sich ein erheblich heterogenes Bild, da lediglich die DummyVariable für Ungarn Signifikanz in allen drei Regressionen erreicht, dabei aber bezüglich ihrer Koeffizientengröße erhebliche Ungereimtheiten aufweist. Andere Länder-Variablen erscheinen maximal in einer der drei Regressionen signifikant.

Insgesamt haben die drei Regressionen aber nur einen sehr geringen Erklärungsgrad für die Wettbewerbsposition der jeweiligen Unternehmen.

Zusammenfassend ist festzuhalten: Gesamteuropäisch ist die Effektivität staatlicher Innovationsförderung kritisch zu hinterfragen, da deren Effekt im Rahmen der Average Treatment Effects of the Treated kaum belegbar und vor allem auch mit Blick auf ihre Wirkungsweise hochgradig unklar ist. Ländereffekte bestehen stark, was eine weitere Untersuchung einzelner Länder sinnvoll erscheinen lässt. Mit Blick auf die unterschiedlichen Einflussfaktoren auf die Wettbewerbsfähigkeit zeichnet sich bei Arbeitsproduktivität eine positive Wirkung der Förderung ab, die jedoch für den Umsatz nicht gefunden werden kann. Weiterhin üben andere Faktoren mit Blick auf die Wettbewerbsfähigkeit einen stärkeren Einfluss aus.

\subsection{Föderalismus in der staatlichen Innovationsförderung: Wirkung föderaler Strukturen und ihre Politikimplikationen}

Im fünften und letzten Kapitel werden anhand der Daten der vorherigen Kapitel und anhand der bisher vorliegenden Studien zu den unterschiedlichen Förderebenen Folgerungen gezogen und Politikimplikationen abgeleitet. Ein Fokus liegt hierbei wiederum auf der Perspektive für Deutschland. Darüber hinaus wird eine generelle Würdigung staatlicher Innovationsförderung bei föderalen Strukturen in Europa vorgenommen.

Nach einer grundsätzlichen Skizze der unterschiedlichen Entwicklungen in Europa sowie der Ergebnisse der vorherigen Kapitel wird festgestellt, dass unterschiedliche Förderebenen in Deutschland klar unterschiedliche Zielgruppen von Unternehmen ansprechen. Obgleich keine feste Koordinierungsstruktur vorhanden ist, kommt es also nicht etwa zu einer Vervielfachung der Bürokratie, sondern zu einer Diversifikation der angesprochenen Unternehmen.

Im europäischen Vergleich wird sichtbar, dass kleine und mittlere Unternehmen bei der Erreichbarkeit von Fördermitteln für die Innovationstätigkeit erhebliche Vorteile in föderalen und semiföderalen Systemen haben und in zentralistischen Systemen eher mit größeren Nachteilen konfrontiert sind. Insgesamt lässt sich also in diesem Kontext eine Vorteilhaftigkeit dezentraler und föderaler Strukturen ableiten.

Gleichzeitig muss sowohl in Deutschland als auch im europäischen Vergleich die Effektivität der Innovationsförderung mit Blick auf die Wettbewerbsfähigkeit der Unternehmen äußerst kritisch hinterfragt werden. Positive Effekte sind in Deutschland nur für Programme der nationalen 
Ebene sichtbar und im europäischen Vergleich zwar insgesamt zu erahnen, aber nicht signifikant. Mit Blick auf die Effektivität staatlicher Innovationsförderung sollte es deshalb zukünftig nicht genügen, nur die Additionalität staatlicher Förderung, dass also kein CrowdingOut vorliegt, zu untersuchen, sondern vielmehr sollten die Wirkungen auf Innovationsaktivitäten, deren Wirkung auf die Wettbewerbsfähigkeit sowie die Effektivität der Förderung stärker in den Fokus der Forschung rücken.

Insgesamt zeigen sich eine deutlich größere Vielfalt und eine Vorteilhaftigkeit föderaler Strukturen gerade für kleine und mittlere Unternehmen, die allerdings mit Effektivitätseinbußen einhergeht.

Als Politikimplikationen sind daraus eine stärkere Fokussierung auf dezentrale Strukturen, insbesondere zur Unterstützung von Firmen mit Hindernissen zur Innovationstätigkeit, ebenso wie intensivere Koordinierungsbemühungen zur besseren Verzahnung der Ebenen und eine stärkere Orientierung der Evaluation von Maßnahmen mit Blick auf die Steigerung der Wettbewerbsfähigkeit anzuregen. 


\section{Literaturverzeichnis}

o.V. (2010), 'Merkel lobt Mittelstand als "Rückgrat" der Wirtschaft', DeutscheHandwerksZeitung, 4 Nov <http://www.deutsche-handwerks-zeitung.de/merkel-lobt-mittelstand-als-rueckgrat-derwirtschaft/150/3092/68935>, zuletzt geprüft am 11. Mär. 2015.

Aerts, K. und Czarnitzki, D. (2004), Using Innovation Survey Data to Evaluate R\&D Policy: The Case of Belgium, ZEW Discussion Paper, No. 04-55 (Mannheim) <ftp://ftp.zew.de/pub/zewdocs/dp/dp0455.pdf>, zuletzt geprüft am 11. Mär. 2015.

Arrow, K. J. (1962), 'Economic welfare and the allocation of resources for invention', in Universities National Bureau Committee for Economic Research (ed.), The rate and direction of inventive activity. economic and social factors, a conference of the Universities-National Bureau Committee for Economic Research and the Committee on Economic Growth of the Social Science Research Council, 609-25.

Asplund, R. (2000) (Hrsg.), Public R \& D funding, technological competitiveness, productivity, and job creation (Etla. B, 168, Helsinki: Taloustieto).

Audretsch, D. B. (2001), The dynamic role of small firms : evidence from the US (Washington D.C.).

Becker, L. (2012), 'Innovation subsidies in a federal system. Innovation policy at different political levels in Germany', in GSTF and M. Hunter (eds.), Proceedings of the 2nd annual International Conference on Innovation and Entrepreneurship (IE 2012) (Singapore: GSTF), 59-64.

Belitz, H., Eickelpasch, A. und Lejpras, A. (2010), 'Technologieoffene Förderung - Zentrale Stütze der Industrieforschung in Ostdeutschland', Wochenbericht des DIW Berlin, 77/51-52: 210.

Blanes, J. V. und Busom, I. (2004), 'Who participates in R\&D subsidy programs?: The case of Spanish manufacturing firms', Research Policy, 33/10: 1459-1476 <http://www.sciencedirect.com/science/article/B6V77-4DXBGRH1/2/e5d85513d730e85114416b83ecb93e95>.

Brouwer, M. T. (2000), 'Entrepreneurship and uncertainty: innovation and competition among the many', Small Business Economics, 15/2: 149-160 <http://www.springerlink.com/content/n128n516370564j8/fulltext.pdf>.

Busom, I. und Fernández-Ribas, A. (2007), 'Do R\&D Programs of Different Government Levels Overlap in the European Union?', in , Science, Technology and Innovation Policy, 1-5.

Cantner, U. und Kösters, S. (2012), 'Picking the winner? Empirical evidence on the targeting of R\&D subsidies to start-ups', Small Business Economics, 39/4: 921-936.

Cerulli, G. (2010), 'Modelling and measuring the effect of public subsidies on business R\&D. A critical review of the econometric literature', The economic record : er, 86/274: 421-449.

Cohen, W. M. (2010), 'Fifty years of empirical studies of innovative activity and performance', in B. H. Hall and N. Rosenberg (eds.), Handbook of the economics of innovation (Amsterdam [u.a.]: North Holland), 129-213.

Cohen, W. M. und Levin, R. C. (1989), 'Empirical studies of innovation and market structure', in R. Schmalensee and R. D. Willig (eds.), Handbook of industrial organization (Handbooks in economics, 10, Amsterdam, London: North-Holland), 1059-107.

Czarnitzki, D. und Fier, A. (2002), 'Do Innovation Subsidies Crowd Out Private Investment? Evidence from the German Service Sector', Applied Economics Quarterly (Konjunkturpolitik), 48/1: 1-25 <http://econstor.eu/bitstream/10419/24802/1/dp0204.pdf>.

Czarnitzki, D. und Toole, A. A. (2008), The $R \& D$ investment uncertainty relationship: Do competition and firm size matter?, Discussion paper / ZEW Zentrum für Europäische Wirtschaftsforschung (Mannheim) <http://ftp.zew.de/pub/zew-docs/dp/dp08013.pdf>, zuletzt geprüft am 11. Mär. 2015. 
Duguet, E. (2004), 'Are R\&D subsidies a substitute or a complement to privately funded R\&D ? An econometric analysis at the firm level', Revue d'Economie Politique, 114/2: 245-274 $<\mathrm{http}: / /$ www.cairn.info/revue-d-economie-politique-2004-2.htm>.

Erlei, M., Leschke, M. und Sauerland, D. (2007), Neue Institutionenökonomik (2., überarb. und erw. Aufl., Stuttgart: Schäffer-Poeschel) <http://deposit.d-nb.de/cgi-

bin/dokserv?id=2890495\&prov=M\&dok_var=1\&dok_ext=htm>.

European Commission (2013), State Aid Scoreboard 2013: Non-crisis aid <http://ec.europa.eu/competition/state_aid/scoreboard/non_crisis_en.html>, zuletzt geprüft am 19. Jun. 2014.

—_ (2014a), 2014 SBA Fact Sheet: Germany $<\mathrm{http}: / /$ ec.europa.eu/enterprise/policies/sme/facts-figures-analysis/performancereview/files/countries-sheets/2014/germany_en.pdf>, zuletzt geprüft am 15. Feb. 2015. —_ (2014b), State Aid Scoreboard 2014: Non-crisis aid <http://ec.europa.eu/competition/state_aid/scoreboard/non_crisis_en.html>, zuletzt geprüft am 15. Feb. 2015.

Eurostat, Community Innovation Survey (CIS) (Luxemburg).

Fernández-Ribas, A. (2009), 'Public support to private innovation in multi-level governance systems: an empirical investigation', Science and Public Policy, 36: 457-467 <http://www.ingentaconnect.com/content/beech/spp/2009/00000036/00000006/art00004 http://dx.doi.org/10.3152/030234209X460953>.

Görg, H. und Strobl, E. (2007), 'The Effect of R\&D Subsidies on Private R\&D', Economica, 74/294: 215-234 <http://dx.doi.org/10.1111/j.1468-0335.2006.00547.x>.

Griliches, Z. (1992), 'The Search for R\&D Spillovers', The Scandinavian Journal of Economics, 94: 29-47 <http://www.jstor.org/stable/3440244>.

Grossman, G. M., Helpman und Elhanan (1994), 'Endogenous Innovation in the Theory of Growth', The Journal of Economic Perspectives, , 8/1: 23-44 $<$ http://www.jstor.org/stable/i337439>.

Hussinger, K. (2008), 'R\&D and subsidies at the firm level. An application of parametric and semiparametric two-step selection models', Journal of Applied Econometrics, 23/6: 729-747.

Kolhoff, W. (2002), 'Die SPD entdeckt den Mittelstand', Berliner Zeitung, 16 Apr <http://www.berliner-zeitung.de/archiv/neue-staatsbank-geplant-oekosteuer-wird-eingefrorendie-spd-entdeckt-den-mittelstand,10810590,9989988.html>, zuletzt geprüft am 11. Mär. 2015.

Konings, J. und Torfs, W. (2011), 'Fiscal Federalism, Tax Competition and Economic Agglomeration', in Flemish Department of Finance and Budget (ed.), Fiscal Federalism in the European Union. EU Presidency Seminar (Brussels: Larcier), 35-56.

Kulicke, M., Hufnagl, M., Brandt, T. et al. (2010), Evaluierung des Programmstarts und der Durchführung des "Zentralen Innovationsprogramms Mittelstand (ZIM)": Endbericht (Karlsruhe/Berlin).

Lach, S. (2002), 'Do R\&D Subsidies Stimulate or Displace Private R\&D? Evidence from Israel', The Journal of Industrial Economics, , 50/4: 369-390 <http://www.jstor.org/stable/3569779>.

Levine, R. (1997), 'Financial Development and Economic Growth: Views and Agenda', Journal of Economic Literature, 35/2: 688-726 <http://www.jstor.org/stable/2729790?origin=JSTORpdf>.

Mertins, V. (2009), 'Institutionenökonomische Analyse von Innovationsförderung : eine theoretische und empirische Betrachtung am Beispiel Niedersachsens' (Frankfurt am Main [u.a.], Universität Göttingen).

Müller, C. E. (2012), Quasiexperimentelle Wirkungsevaluation mit Propensity Score Matching:

Ein Leitfaden für die Umsetzung mit Stata, CEval-Arbeitspapiere, No. 19 (Saarbrücken) <http://www.ceval.de/typo3/fileadmin/user_upload/PDFs/Workpaper19.pdf>, zuletzt geprüft am 11. Mär. 2015.

Neumann, M. (1971), 'Zur ökonomischen Theorie des Föderalismus', Kyklos, 24/3: 493-510. 
Oates, W. E. (1972), Fiscal federalism (The Harbrace series in business and economics, New York, NY: Harcourt Brace Jovanovich).

Oates, W. E. (2005), 'Toward a second-generation theory of fiscal federalism', International tax and public finance, 12/4: 349-373.

OECD (1997), Oslo manual : Proposed guidelines for collecting and interpreting technological innovation data (Paris) <http://www.oecd.org/dataoecd/35/61/2367580.pdf >.

Radicic, D. und Pugh, G. (2013), 'The impact of innovation support programmes on SME innovation in traditional manufacturing industries. an evaluation for seven EU regions', in DRUID society (ed.), Conference Proceedings DRUID Academy 2013 (online) $<$ http://druid8.sit.aau.dk/acc_papers/bqon0p6k7nppx07f6gk96qmm0cte.pdf>, zuletzt geprüft am 15. Okt. 2014.

Schumpeter, J. A. (1934), Theorie der wirtschaftlichen Entwicklung (4. Aufl., München: Duncker \& Humblot), Erstveröffentlichung: 1911. (2008), Capitalism, socialism and democracy (3. Aufl., New York, NY [u. a.]: Harper Perennial Modern Classics), Erstveröffentlichung: 1942.

Thomä, J. (2012), Kleine und mittlere Unternehmen mit Besonderheiten?: Beiträge zur Mittelstandsforschung an den Beispielen von Innovation und Konjunktur (Göttingen: Niedersächsische Staats- und Universitätsbibliothek Göttingen).

Thomä, J. und Bizer, K. (2013), 'To protect or not to protect? Modes of appropriability in the small enterprise sector', Research Policy, 42/1: 35-49.

Tiebout, C. M. (1956), 'A pure theory of local expenditures', Journal of Political Economy, 64/5: 416-424.

Vitola, A. (2014), 'Innovation policy mix in a multi-level context. The case of the Baltic Sea Region countries', Science and Public Policy, 2014.

Wallsten, S. J. (2000), 'The effects of government-industry R\&D programs on private R\&D: the case of the Small Business Innovation Research program', RAND Journal of Economics (RAND Journal of Economics), 31/1: 82-100 <http://search.ebscohost.com/login.aspx?direct=true\&db=buh\&AN=3053312\&site=ehost-live $>$. Wooldridge, J. M. (2010), Econometric analysis of cross section and panel data (2. ed, Cambridge, Mass.: MIT Press).

ZEW, Mannheim Innovation Panel (MIP) (Mannheim). 
Kapitel 2

\section{No gains of federalism in innovation support?}

\section{The case of Germany}

Veröffentlicht in: DRUID Society (Hg.): Conference Proceedings 35th DRUID Celebration Conference 2013. 35th DRUID Celebration Conference 2013. Barcelona. DRUID society: online: http://druid8.sit.aau.dk/druid/acc_papers/rv1s78ke8jm7n4Irad6udnov2bld.pdf im Juni 2013 


\section{Abstract}

This paper examines the characteristics of firms receiving public innovation support, as well as its effectiveness from different levels in Germany. It expands the view on innovation policy especially regarding federal structures. While other studies assume a homogeneous innovation policy within a country, the paper analyses the specific gains of federalism. The focus for Germany lies at the state, national or European level, each of which offers forms of innovation support.

The results of the first logistic regressions show that many firm characteristics differ between the state, federal and European level, while some characteristics are similar across all levels. Additionally, regional differences between German states ("Bundeslaender") become visible; for instance, firms in eastern Germany receive more frequently innovation support at all levels. While smaller firms receive less support at the federal and European level, regional programmes better reach such firms.

In a second set of regressions, the paper analyses the influences of innovation support on increasing or declining turnover and return on sales, finding that the effectiveness of innovation subsidies is only evident at the federal level in terms of an increase in the respective firm's competitiveness.

Accordingly, federal structures and regional programmes have a positive influence on opening the public innovation framework to a broader variety of firms. By contrast, regarding effectiveness, the gains of federal structures are deniable for the regional and European level.

\section{Keywords}

Innovation, innovation policy, federalism, subsidies, Germany

\section{JEL Classification}

O31, O38, H32, H77 


\section{Introduction}

Governments at all levels claim the importance of innovativeness for regional economic growth and competitiveness and use different measures of innovation support to foster innovativeness within their respective jurisdictions. The importance of innovativeness for economic development and growth starts with Schumpeter (1942/2008), who claims that 'creative destruction' is an engine of development and growth. Other more recent authors like Brouwer (2000: 149) proclaim the importance of innovation towards economic growth based upon Schumpeter's theories.

Governments offer innovation support via subsidies, tax-cuts, protective legislation or supportive infrastructure because they want to enhance private firms' innovation activities. With very few exceptions (essentially Fernández-Ribas 2009 for Spain), the literature considers innovation and R\&D policy to be homogeneous within a country (Fier and Czarnitzki 2005 for Germany; Duguet 2004 for France; Aerts and Czarnitzki 2004 for Belgium).

However, this assumption is questionable as several countries are based upon a federal system - like Germany -or are closely linked to multi-level government structures - like the European Union. Federal countries within the European Union include Belgium and Germany, while centralist countries include Portugal, France and Ireland (compare Lijphart 2012: 178). As only very few empirical studies describe the impact of federalism on the field of innovation, this study closes this gap by evaluating both the characteristics of publicly supported firms and the effectiveness of public innovation support on firm competitiveness in Germany. In the Federal Republic of Germany, the influence of three different political levels has to be addressed: according to Kulicke et al. (2010: 79), fifteen of the sixteen German states ("Bundeslaender") offer general innovation subsidies in addition to those offered by the federal government and the supranational European structures. By offering more than $€ 500$ million of innovation support, the federal programme "Zentrales Innovationsprogramm Mittelstand (ZIM)" is the largest support programme, while state programmes vary widely between states. The paper assesses the consequences of different levels of support for Germany, namely the question of whether the different states' innovation policies solely add a third level of bureaucracy or whether they offer the possibility to reach out to a wider variety of firms supported and thus increase the impact of government spending.

After reviewing the literature on innovation support in the second part of this paper and linking the fields of innovation, federalism and public spending, the third part builds hypotheses based upon the core questions mentioned above. The fourth part describes the dataset and the 
variables chosen, before the results of both the firm characteristics of recipients and the effects of public support on output variables form the fifth part. With the conclusion in the sixth part, results are placed in the context of the public innovation framework for policy implications and the current scientific situation in terms of further research.

\section{Literature review}

\subsection{Justification of public innovation support}

If individuals and private firms create new ideas and innovations, the question arises why government intervention to support private investment can be necessary and justified. Considering this question, empiric literature examines the socially optimal level of innovation and its allocation in reality.

Czarnitzki et al. (2011: 217) and earlier Arrow (1962) justify public support for innovation with either governments' demand for new technologies or market failures resulting from underinvestment. The effect of private under-investment due to market failures is particularly relevant for this paper: 'So R\&D expenditures will be either too large or too small, which in both cases calls for government interference' Grossman and Helpman 1991: 106; compare also Brouwer 2000: 150).

Görg and Strobl (2007: 215) stress that the social return of R\&D activity is bigger than the private return, even if hard to measure (see Griliches 1992: S31). Although studies such as Wallsten (2000: 83) criticize the means of innovation support and question its additionality, they agree that 'the social returns to private $R \& D$ are often higher than the private returns, some research projects would benefit society but would be privately [unprofitable]'.

When firms start their investment if it is profitable (Grossman et al. 1994: 27), different aspects reduce the profitability of investment in innovation. For instance, either externalities (Nelson 1959: 305-6) or uncertainty (Grossman et al. 1994: 37-8; Brouwer 2000: 150) combined with the special attributes of the good 'innovation' might reduce private profits and thus the incentive to innovative activities.

External effects regarding innovation activities include the classical problems of public goods. Griliches (1992: S31) refers to innovation as 'a non-rivalrous good' and suggests that 'it is usually very hard to appropriate more than a tiny fraction of its social returns. Even if it were possible to establish some property rights in the idea (e.g. via patents), the resulting second-best prices would be nonlinear and would not provide us with appropriate measures of either marginal or total social returns.' 
Facing uncertainty, private actors are unable to know whether an innovation will be a success or a failure, as well as whether a competitor is working on a similar innovation at the same time; indeed, these uncertainties influence the likelihood of innovating, given that without uncertainty, more competition would foster innovation (Loury 1979: 396). In fact, a more diverse structure of innovation activities would reduce the effects of uncertainty, as Levine (1997: 694) outlines:

'The ability to hold a diversified portfolio of innovative projects reduces risk and promotes investment in growth-enhancing innovative activities (with sufficiently risk averse agents).'

In particular, small- and medium-sized enterprises are unable to diversify their innovation portfolios due to their limited capacities, which justifies a special focus on such firms. In addition, not only different concepts regarding protection regimes in SMEs exist, but also employment policies and tacit knowledge, which make smaller firms different from others (Thomä and Bizer 2013).

In general, authors agree that public support for private innovative activities is justifiable, although its effects and the influence of federalism on this field have to be evaluated.

\subsection{Theory of federalism and its relation to innovation}

Federalism exists in a variety of forms around the globe. In several federal countries such as the United States of America or Germany, federal structures mainly influence the system of innovation policy as regional jurisdictions or a combination of national and regional jurisdictions grant innovation support. While Oates (1972: 14) outlines 'the optimal form of government: a federal system', it has to be analysed whether this is also the case regarding innovation policy. While Switzerland is considered as one of the most federal countries in Europe, the Swiss innovation framework marks innovation support as a topic solely handled by the federal government and seldom by regional authorities.

Generally, the implementation of federalism depends upon the level of decentralization (Oates 1972: 19; Tiebout 1956: 424) and its internal organization (Lijphart 2012: 174-86).

The advantages of a federal structure according to economic theories include a smaller state and the reduction of the 'leviathan' (Oates 2005: 355; Pitlik 1997; Feld 2007), a stronger influence of the preferences within a jurisdiction (Oates 1972: 11-2; Hausner 2005: 56; Neumann 1971: 500; Erlei et al. 2007: 440-1) and thus lower 'frustration costs' (Hausner 2005: 57; Blankart 2006: 597-8), a higher, greater openness to establishing new and innovative programmes (Blankart 2006: 598), and the greater accountability of political actors at the regional level (Oates 2005: 358). Transferring these theoretical advantages into a federal framework on innovation, it theoretically means more efficient innovation support, as well as a clear focus on the regional innovative system and its comparative advantages. Less innovative 
actors would theoretically be unable to gain public support and an increased transparency of regional actors offering innovation support would exist.

By contrast, higher coordination is necessary (Wilson and Souitaris 2002: 1135-6) in a federal system, decentralized systems do not use the same economies of scale (Blankart 2006: 600-2) and the externalities of pure public goods fail to result in socially optimal supply levels of a good (Oates 1972: 9). The theoretical disadvantages mean higher transaction costs for policy-makers to coordinate their innovation framework, higher bureaucracy costs and less accessibility for larger projects, and - due to externalities across jurisdictions - the persisting lack of a socially optimal level of innovative activities (Konings and Torfs 2011: 39). Economies of scale are a particularly relevant factor, seeking the regional agglomeration of innovative partners such as firms, laboratories and other research facilities, caused by knowledge spill-overs and the attributes of non-codified knowledge (compare Ács and Varga 2005: 326).

Furthermore, empirical literature suggests that regional innovation programmes become more important in Europe as the knowledge of regional characteristics opens greater possibilities to focus on the unique necessities in each jurisdiction (see Fernández-Ribas 2009: 458-9). Many different levels and systems of regionalization and innovation support programmes can be found worldwide (OECD 2011: 98-9) as well as within Germany (Kulicke et al. 2010: 212-21). In Europe, the influence of regional programmes and regional governments has grown, as mentioned by Fernández-Ribas (2009: 457). In Germany, where a broad regional autonomy exists (OECD 2011: 71), a wide range of different approaches regarding states' innovation policy is also evident (OECD 2011: 44). Nevertheless, Schmalholz (2005: 19) concludes that many innovation programmes in German states focus on similar targets, which makes a closer link to regional preferences and fields of regional comparative advantages at least partially questionable and worth investigating in further detail.

Federalism influences the innovation policy framework - especially in Germany - but whether this influence is positive or negative remains unclear.

\subsection{Innovation support and its empirical impact}

The impact of innovation support - either through innovation subsidies or tax reduction remains the focus of several studies. However, as shown in Becker (2012) aside from few exceptions such as Fernández-Ribas (2009), most authors claim that the structure of innovation support within a country is homogenous, although some studies like Belitz et al. (2010: 6) or Busom and Fernández-Ribas (2007) stress that subsidies are offered at different levels in Europe. Nonetheless, these studies offer the possibility to observe important facts about the nature of innovation support and $R \& D$ support, both of which are the subject of many studies. 
Most studies show the additionality (at least partially) of public money spent on innovation and R\&D support in general (Duguet 2004: 272 for France; Aerts and Czarnitzki 2004: 16 for Belgium; Czarnitzki and Fier 2002: 17-8 for Germany).

Busom (2000: 133) shows the positive effect of support programmes but also stresses that the possibility of crowding-out cannot be completely ruled out in Spain. For Ireland, Görg and Strobl (2007: 231) note that public support will not crowd out private investment for domestic firms that receive small grants, although the effect is unclear regarding larger grants and multinational firms. Lach (2002: 389) finds similar results as he does not completely reject a crowding-out but highlights the lower substitution of private spending by public support for smaller firms in Israel. Whereas Wallsten (2000: 97-8) claims that significant and complete crowding-out effects are related to public funding on R\&D through the SBIR programme in North America, Levy (1990: 172) earlier analysed that innovation support is complementary to private investments in several states of the US, while it is substitutionary in others.

By contrast, Hall and van Reenen (2000: 462) show that one dollar of public innovation support induces another dollar of private investment in North America, whereas the effect claimed by Fier and Czarnitzki (2005: 4) is smaller in Germany (with 0.28 euro private investment induced by one euro of public spending).

Krohmer (2010: 51) also supports the additionality and emphasizes that there is generally no crowding-out of private investments, based upon an analysis of 57 studies focused on R\&D support. The structure of firms supported shows that larger firms typically have easier access to innovation support in both France (Duguet 2004: 245) and in Spain (Busom and FernándezRibas 2007: 4)

Regarding the structure of innovation support in Germany, Kulicke et al. (2010: 79) emphasize that - aside from Baden-Wuerttemberg - all German states offer general ${ }^{1}$ innovation support programmes. Grenzmann et al. (2010: 387) highlight the importance of private spending on R\&D, which accounts for approximately 90 per cent of R\&D spending in Germany. Belitz et al. (2010: 6) add the aspect that regional programmes in Germany focus on selective fields of technology rather than general support.

In terms of federal structures, the findings of Fernández-Ribas (2009: 463-5) show for Spain that regional innovation programmes support firms with higher barriers to innovate and less knowledge of innovation programmes.

\footnotetext{
${ }^{1}$ In contrast to specific innovation programmes, such as supporting energy efficiency or special technologies.
} 
Apart from Wallsten (2000), the empiric literature at least partially confirms additionality, which creates a general hint against the complete ineffectiveness (or in favor of effectiveness) of innovation grants.

\section{Hypotheses}

The purpose of this paper is to test the effect of federal structures on innovative activities. By building five operationable hypotheses, the paper analyses the innovation framework in Germany, including the impact of federalism.

Hypothesis 1: Small and medium-sized enterprises (SME) face greater difficulties in gaining national and supranational innovation support compared with regional innovation support.

Based upon the assumption of lower frustration costs and a closer link to regionally more homogenous preferences, regional programmes should have the opportunity to reduce barriers, especially for small- and medium-sized enterprises and those that have problems innovating. This hypothesis is in line with the findings of Fernández-Ribas (2009: 463), who states the following: 'Interestingly, firms with major limitations to innovate are more likely to participate in regional and local programmes'.

Hypothesis 2: Regional influences and differences exist between the state and federal level within Germany.

If this were not the case, the general assumption of a homogenous structure of innovation support given in other papers would be preferable and federal structures would not support firms with different firm characteristics. The study includes tests for different regional influences and their effects on innovation support.

Hypothesis 3: Regional programmes focus more intensely on firms with a regional focus. Hypothesis 3 focuses on regional preferences and regional circumstances, as mentioned above and in Oates (1972: 11-2) and Blankart (2006: 597-8). A regional focus reduces the frustration costs of regional innovators and enhances a closer focus on the situation of the jurisdiction.

Hypothesis 4: Firms that regularly spend money on innovation access innovation support more easily than other firms. 
This hypothesis is relevant for further research and forms a basis to characterize firms gaining innovation support. It tests for possible path dependency and might influence all levels of the innovation policy framework.

\section{Hypothesis 5: Supported firms are more competitive than those without innovation support.}

In addition to the hypotheses focused on firm and market characteristics, hypothesis 5 offers the possibility to examine at least some aspects of the firm's effectiveness. As mentioned by the OECD (2011: 31) and Atkinson (1991: 563), the effectiveness and efficiency of support programmes is important.

\section{$4 \quad$ Data and methods}

\subsection{Data}

In order to examine the effects and target groups of regional, national or supranational innovation support, an econometric approach regarding the empirical backgrounds of firms that receive innovation subsidies is adequate. Given that most of the programmes supporting innovative activities focus on SMEs, this study observes firm size and other characteristics that influence the reception of innovation support.

Focusing on innovation support in Germany, the existing data of the Mannheim Innovation Panel (MIP) of the Centre for European Economic Research (ZEW) forms a solid base to analyse the economic framework: Approximately 6,000 firms participate annually in the written questionnaire. Every second year, the questionnaire includes questions referring to the political level of support. As a combination of different waves of the MIP as an unbalanced panel would significantly reduce the number of observations, the data collection wave of the MIP from $2007^{2}$ forms the general dataset for this paper in a cross-sectional analysis. The study only includes in the regressions those firms that answered all questions examined in this paper, which reduces the sample to 1,259 observations. The sample comprises 6,069 observations for the second set of regressions, examining the effects of public innovation support on output variables such as turnover and return on sales, given that more firms answered all relevant questions for these regressions.

\footnotetext{
2 The data on public support is included every second year in the MIP. The results are very similar to other earlier data waves or combined data of different data waves. Compare for combined data of the data waves 2005 and 2007 Appendix (see p.15).
} 
Compared with other datasets for Germany such as the Kreditanstalt für Wiederaufbau (KfW), the data of the MIP more strongly focuses on innovative firms and reaches more firms on average (compare Rothgang and Dürig 2009: 269).

\subsection{Methods}

Using the data of the MIP, the study compares all three different political levels that offer innovation support in Germany, namely the regional state level ("Bundeslaender"), the federal level ("Bund") and the supranational European level ("EU"). The paper examines the reception of public innovation support as the dependent variable in an econometric model. This dependent variable is binary coded, whereby I choose a binary model - in this case a Logit-regression - to evaluate which characteristics of a firm influence the reception of innovation support. In order to make the interpretation easier, I include the odds ratio, which allows comparing the effects of the different variables.

Furthermore, the study tests for the effectiveness of the public support by evaluating the influence of the subsidies in terms of changes in turnover and return on sales with a second set of logistic regressions.

The study additionally estimates the logistic regressions with robust errors to prevent the dependency of error terms or heteroscedasticity in the appendix. However, these estimations show the same results as the regressions in table 2 .

Table 1: Descriptive statistics on the usage of innovation support measures by support level

\begin{tabular}{lllll}
\hline & $\mathbf{N}$ & $\%$ & Mean & Std. Dev. \\
\cline { 2 - 5 } State Level Support & 235 & 18.7 & 0.1867 & 0.3898 \\
Federal Level Support & 341 & 27.1 & 0.2708 & 0.4446 \\
European Level & 137 & 11.0 & 0.1096 & 0.3125 \\
Support & & & & \\
\hline
\end{tabular}

Data: ZEW MIP 2007; Notes: Calculated with Stata (2014); N = number of firms, \% = share of sample.

\subsection{Variables}

Based upon similar studies such as Busom and Fernández-Ribas (2007) and Fernández-Ribas (2009) for Spain, I choose a general set of variables and expand it with further potentially interesting variables. Busom and Fernández-Ribas (2007) focus on the overlap between different levels with general independent variables, such as the wage-level for researchers or the share of high-skilled employees. By adding other explanatory variables like the SME definition of 
the European Union as a dummy, or dummy variables for German regions, I broaden the influences analysed.

Twelve independent variables explain the dependent variables suppst (public innovation support granted by the state level), suppfe (public innovation support granted by the federal level) and suppeu (public innovation support granted by the European level). ${ }^{3}$

To check for interactions between the different support levels, I include the two other support dummy variables as explanatory variables (suppst, suppfe or suppeu). As common goals between different support programmes exist, a positive influence is expected.

Regarding the importance of firm size and the earlier described problems of smaller firms to innovate, the first explanatory variable is sme, which is a dummy variable for firms covered by the SME definition of the European Union ${ }^{4}$ and is used to test hypothesis 1 . I expect a negative influence, whereby smaller firms face barriers accessing public innovation support.

The regional dummy variable east shows whether the firm is located in eastern Germany, which might indicate easier access to public transfers due to the transition process. In an effort to increase innovativeness in eastern Germany, more funds supporting private firms are available from all levels. By contrast, donor indicates whether a firm is active in a state that is net payer in the German federal fiscal relations between states. Through the federal fiscal relations, wealthier donor states have to transfer money to their poorer counterparts. During the evaluated period, five states were donor states while eleven were recipients. These two variables allow testing the regional focus in hypothesis 2 . The database of the MIP does not allow adding further state-level data for single states as the number of observations would be too small. ${ }^{5}$ Given that the access for firms in eastern Germany should generally be easier, the coefficient is supposed to be positive, while the access for firms in donor states is supposed to be more difficult as most of the programmes focus on regions with problems regarding competitiveness.

In order to test for the market surroundings and market focus of hypothesis 3 , the market share mshare is also included as a dummy for the national and international market focus (compared

\footnotetext{
3 For all three support variables, missing variables due to the questionnaire have been added. Firms often only complete the questionnaire for the level from which they have received support. Therefore, if only one level is completed, missing values for these firms at other levels are set to 0 .

4 The data of the MIP only allows using the number of employees and the turnover. Data on the balance sheet is not available.

${ }^{5}$ Attempts to add state level data for five states that had the largest number of observations showed at an earlier stage of this paper similar results, albeit also with significant statistical problems.
} 
to the regional market focus). The dummy variable qualcomp explains whether there is strong or very strong competition regarding quality. The paper expects that all market share and qualitative competition variables show a positive coefficient at all three levels, while the effects of national or international market focus are expected to be positive at the federal and European level.

To examine hypothesis 4 , the study chooses several variables. Inrdexp uses the expenditure spent on R\&D (in logs) to show the amount of money spent on R\&D within the firm, which is similar to both studies from Spain. In addition, hiedu gives a more general indicator of whether the firm is a white- or blue-collar firm, indicating the share of employees with higher degrees of education. As path dependence might appear upon closer focus, the dummy variable regularly indicates whether the firm had already been active in innovation processes during the previous two years (in this case before 2007). All variables are supposed to show positive coefficients in all regressions as these surroundings increase the likelihood of innovation and thus the likelihood of receiving innovation support.

The variables together open a broad view of factors that influence the reception of public innovation support. In the appendix, I also include the lagged variables suppst05, suppfe05 and suppeu05, which show whether a firm received public support two years before, whereby the expected positive influence would provide evidence of existing path dependency. However, due to the unbalanced nature of the dataset, only 503 observations remain.

Additional variables that Busom and Fernández-Ribas (2007) or Becker (2012) include - such as the firm's investments in trainings, being part of a multinational firm or the export share - are omitted for Germany to reduce the number of variables included.

The study estimates three different models - one for each level of innovation support - in order to show the different influences.

Several newly created dummy variables form the test on the effectiveness of public innovation subsidies. They change their value if the turnover, respectively the return on sales, rose or fell between 2005 and 2007. I choose these output variables as they are available in the existing data and can be seen as indicators for a change of competitiveness in a firm. Rises and falls in both scales can be subscribed by the respective dummy variables turnup and turndown or rosup and rosdown as dependent variables.

As independent variables in the effectiveness test, the study uses the reception of public innovation subsidies from the three levels mentioned above (suppst, suppfe, suppeu). Therefore, a test for the effect of getting public innovation subsidies on turnover and return on sales is included with the second set of logistic regressions. If public support programmes work effectively, all coefficients are supposed to be positive. 


\section{$5 \quad$ Results}

\subsection{Firm characteristics and their impact on the reception of public innovation support}

Whether the diverse attributes of firms influence the likelihood of receiving public support from different political levels is the core question of an empirical approach regarding federalism and innovation policy.

Table 2 shows the empirical findings of the three logistic regressions on firm characteristics. All three levels have in common that interaction with other levels of support is one of the strongest positive factors to influence another support level: all interaction terms with other support levels are highly significant and have a high odds ratio. Moreover, other factors such as the regional location in eastern Germany east influence all levels of support. The regional position in eastern Germany positively influences the likelihood of state and federal programmes, in contrast to a negative (albeit smaller and less significant) influence at the European level.

At the state level, both regional factors east and donor are significant. The location of a firm reduces the likelihood of support at the regional level if the state is a net payer to the German federal fiscal system. Expenditure on research and development Inrdexp has a positive (and significant) influence at the state and European level.

At the federal level, the degree of quality competition is particularly important: qualcomp is only significant at the federal level and shows a higher odds ratio compared with the other levels.

The continuity of innovative activities regularly and the share of higher educated employees highedu influence both the federal and European level positively with strong significance, while they are insignificant at the state level.

Regarding firm size, the dummy variable sme is not significant at the state level, although its coefficient is only positive there, with a higher odds ratio than at the other levels. A small firm size influences the likelihood of being supported at the federal and European level negatively. However, this negative impact is only statistically significant at the European level, at a 10 percent level.

Additionally, market characteristics have a stronger and different influence at the European level compared with the state and federal level. A higher market share mshare increases the likelihood of being supported, whereas the European level support focuses on regional firms, given that the coefficients for firms with a national and international market focus are only negative at the European level and for national also significant at a 5 percent level.

Caution is necessary when evaluating possible path dependency. Some other variables changed their coefficients due to the reduced database in table $A 1$, although the high 
significance of all lagged support variables suppst05, suppfe05 and suppeu05 is evident at least for the reduced sample path dependency.

In general, the findings show that different political levels supporting innovation interact. Furthermore, they outline that all three levels of the innovation policy framework in Germany reach firms with different firm characteristics. However, this does not clarify the effectiveness and the goals of the programmes.

\subsection{Public innovation support and its effect on firm competitiveness}

With regard to effectiveness of innovation support, output oriented measures have to be considered. Governments often implement support programmes - especially regional programmes - in order to increase competitiveness, with the OECD (2011: 31) stating that 'many OECD regions are formulating regional innovation strategies to increase their economic competitiveness'.

Output variables such as turnover and return on sales offer the possibility to compare the change in economic competitiveness and market position. Therefore, I use dummy variables for a rise (turnup or rosup) or fall (turndown or rosdown) to analyse the connection with public innovation subsidies from the different levels.

The effect on turnover changes indicates that only federal support creates a significant and positive influence on higher turnover at the end of the year, as well as reducing the highly significant risk of declining turnovers. This is in line with growing return on sales, which is also significant.

State level support has no significant influence on turnover growth (albeit nonetheless a negative coefficient), but a significant and positive influence on the likelihood of having reduced turnover at the end of the year.

At the European level, only the coefficient for growth of return on sales reaches significance, although the coefficient is negative. Therefore, firms supported by the European Union are more likely to face a decline in return on sales. It is necessary to outline that the coefficient for the European level in the logistic regression for a turnover rise is positive yet not significant.

As the effects at the state and European level are different and incoherent between turnover and return on sales, there is no clear result for these two levels.

As a constraint to the results, it is necessary to mention the very low Pseudo- $\mathrm{R}^{2}: 6$ Other factors influence turnover and return on sales more than the reception of public support. Nonetheless,

\footnotetext{
6 In order to clarify the results, the sample for the second set of regressions was enlarged to almost the entire data collection wave from 2007.
} 
the unclear direction of the coefficients at the state and European level hints at effectiveness problems.

Summarizing these basic effectiveness tests, a positive effect regarding output measures only becomes clearly visible for the federal level in Germany, while the results for the state and European level are unclear or partially negative. 
Table 2: Attributes of supported firms (logistic regressions, logit)

\begin{tabular}{|c|c|c|c|c|c|c|c|c|c|c|c|c|c|c|c|}
\hline & \multicolumn{5}{|c|}{ Regional level (suppst) } & \multicolumn{5}{|c|}{ National level (suppfe) } & \multicolumn{5}{|c|}{ European level (suppeu) } \\
\hline & Coef. & & $\begin{array}{l}\text { Std. } \\
\text { Err. }\end{array}$ & $\begin{array}{l}\text { Odds } \\
\text { ratio }\end{array}$ & & Coef. & & $\begin{array}{l}\text { Std. } \\
\text { Err. }\end{array}$ & $\begin{array}{l}\text { Odds } \\
\text { ratio }\end{array}$ & & Coef. & & $\begin{array}{l}\text { Std. } \\
\text { Err. }\end{array}$ & $\begin{array}{l}\text { Odds } \\
\text { ratio }\end{array}$ & \\
\hline suppst & & & & & & 1.3399 & $* \star *$ & 0.1817 & 3.8187 & $* \star *$ & 1.2281 & $* * *$ & 0.2345 & 3.4147 & $* * *$ \\
\hline suppfe & 1.3413 & $* * *$ & 0.1820 & 3.8240 & $* * *$ & & & & 4.8022 & & 1.5767 & $* * *$ & 0.2303 & 4.8389 & *** \\
\hline suppeu & 1.1995 & $* * *$ & 0.2313 & 3.3185 & $* * *$ & 1.5691 & $* * *$ & 0.2302 & & $* * *$ & & & & & \\
\hline sme & 0.0231 & & 0.2120 & 1.0233 & & -0.1782 & & 0.1861 & 0.8368 & & -0.5227 & * & 0.2761 & 0.5929 & * \\
\hline Inrdexp & 0.1501 & * & 0.0801 & 1.1620 & * & 0.0511 & & 0.0676 & 1.0525 & & 0.3548 & $\star * *$ & 0.1061 & 1.4260 & $* * *$ \\
\hline highedu & 0.0036 & & 0.0033 & 1.0036 & & 0.0164 & $\star \star \star *$ & 0.0028 & 1.0165 & $\star \star \star *$ & 0.0148 & $\star * *$ & 0.0037 & 1.0149 & $* * *$ \\
\hline regularly & 0.1953 & & 0.2088 & 1.2157 & & 0.6695 & 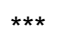 & 0.1845 & 1.9533 & $* \star *$ & 0.5823 & $* *$ & 0.2929 & 1.7901 & $* *$ \\
\hline mshare & -0.0023 & & 0.0035 & 0.9977 & & -0.0007 & & 0.0030 & 0.9993 & & 0.0085 & $\star *$ & 0.0038 & 1.0085 & $* *$ \\
\hline national & 0.1305 & & 0.3128 & 1.1394 & & 0.2315 & & 0.2830 & 1.2605 & & -0.8773 & $* *$ & 0.3495 & 0.4159 & $* *$ \\
\hline international & 0.4546 & & 0.3347 & 1.5756 & & 0.3239 & & 0.3009 & 1.3825 & & -0.5872 & & 0.3690 & 0.5559 & \\
\hline qualcomp & 0.2247 & & 0.2186 & 1.2519 & & 0.4674 & ** & 0.1914 & 1.5958 & ** & -0.2083 & & 0.2536 & 0.8120 & \\
\hline east & 1.3127 & $* * *$ & 0.2535 & 3.7162 & $* \star *$ & 1.1255 & $\star \star * *$ & 0.2388 & 3.0817 & $* * *$ & -0.7736 & $* *$ & 0.3196 & 0.4613 & $* *$ \\
\hline donor & -0.5032 & * & 0.2609 & 0.6046 & * & 0.3086 & & 0.2264 & 1.3615 & & -0.4855 & * & 0.2864 & 0.6154 & * \\
\hline cons & -2.7018 & $* * *$ & 0.5146 & 0.0671 & $* * *$ & -3.4385 & $* \star *$ & 0.4708 & 0.0321 & $* * *$ & -2.0787 & $\star * *$ & 0.6025 & 0.1251 & $* * *$ \\
\hline$L R \operatorname{chi}^{2}$ (12) & 298.38 & & & & & 335.58 & & & & & 209.64 & & & & \\
\hline Prob > chi ${ }^{2}$ & 0.0000 & & & & & 0.0000 & & & & & 0.0000 & & & & \\
\hline Pseudo $R^{2}$ & 0.2462 & & & & & 0.2282 & & & & & 0.2408 & & & & \\
\hline
\end{tabular}

Data: ZEW MIP 2007; Notes: Calculated with Stata (2014); ${ }^{* *}$ denotes significance at $1 \%$ level; ** at $5 \%$ level; ${ }^{*}$ at $10 \%$ level. 
Table 3: Effects of public support on turnover and return on sales (logistic regressions, logit), full sample

\begin{tabular}{|c|c|c|c|c|c|c|c|c|c|c|c|c|c|c|c|c|c|c|c|c|}
\hline & \multicolumn{5}{|c|}{ Turnover Rise (turnup) } & \multicolumn{5}{|c|}{ Turnover Fall (turndown) } & \multicolumn{5}{|c|}{ Return on Sales Rise (rosup) } & \multicolumn{5}{|c|}{ Return on Sales Fall (rosdown) } \\
\hline & Coef. & $\begin{array}{l}\text { Std. } \\
\text { Err. }\end{array}$ & & $\begin{array}{l}\text { Odds } \\
\text { Ratio }\end{array}$ & & Coef. & $\begin{array}{l}\text { Std. } \\
\text { Err. }\end{array}$ & & $\begin{array}{l}\text { Odds } \\
\text { Ratio }\end{array}$ & & Coef. & $\begin{array}{l}\text { Std. } \\
\text { Err. }\end{array}$ & & $\begin{array}{l}\text { Odds } \\
\text { Ratio }\end{array}$ & & Coef. & $\begin{array}{l}\text { Std. } \\
\text { Err. }\end{array}$ & & $\begin{array}{l}\text { Odds } \\
\text { Ratio }\end{array}$ & \\
\hline suppst & -0.1640 & 0.1139 & & 0.8487 & & 0.2316 & 0.1156 & $\star *$ & 1.2606 & ** & 0.0015 & 0.1304 & & 1.0015 & & 0.0758 & 0.1796 & & 1.0787 & \\
\hline suppfe & 0.6039 & 0.1116 & $* * *$ & 1.8292 & $\star \star \star *$ & -0.6078 & 0.1152 & $* * *$ & 0.5445 & $* \star *$ & 0.5279 & 0.1158 & $* * *$ & 1.6954 & $* \star *$ & 0.1483 & 0.1661 & & 1.1599 & \\
\hline suppeu & 0.2172 & 0.1499 & & 1.2426 & & -0.2123 & 0.1539 & & 0.8087 & & 0.2907 & 0.1696 & * & 0.7477 & * & -0.2406 & 0.2417 & & 0.7861 & \\
\hline _cons & 0.3614 & 0.0278 & $* * *$ & 1.4354 & $* * *$ & -0.5254 & 0.0283 & $* * *$ & 0.5913 & $* * *$ & 1.3857 & 0.0341 & $* * *$ & 0.2501 & $* * *$ & -2.2453 & 0.0464 & $\star \star * *$ & 0.1059 & $* * *$ \\
\hline$L R \operatorname{chi}^{2}(3)$ & 43.87 & & & & & 40.13 & & & & & 22.44 & & & & & 1.67 & & & & \\
\hline Prob $>c h i^{2}$ & 0.0000 & & & & & 0.0000 & & & & & 0.0001 & & & & & 0.6442 & & & & \\
\hline Pseudo $R^{2}$ & 0.0054 & & & & & 0.0050 & & & & & 0.0036 & & & & & 0.0004 & & & & \\
\hline
\end{tabular}

Data: ZEW MIP 2007; Notes: Calculated with Stata (2014); ${ }^{* \star *}$ denotes significance at $1 \%$ level; ** at $5 \%$ level; * at $10 \%$ level. 


\section{Conclusion}

Complying with the theory, federal structures influence the likelihood of receiving innovation support in Germany as different support levels focus on different firm characteristics. Nonetheless, the different political levels interact, whereby the result of the high effect of other support levels clearly allows the interpretation that all innovation programmes have a common core. Compared with Becker (2012: 62), the loss in significance for the continuity of innovation activities, higher educated workers and research and development expenditure illustrates possible common characteristics given that the interaction terms include such factors.

Although the results are not as clear as Fernández-Ribas (2009: 464-5), the barriers for smaller firms and those with other limitations are lower at the state level. European level programmes show a clear disadvantage for small- and medium-sized enterprises, while federal programmes also show this negative (albeit not significant) effect. Regional programmes show a positive effect, despite not being significant. For this reason, hypothesis 1 is (weakly) supported.

The empirical findings also weakly support hypothesis 2 . In particular, the spatial effect for a firm being located in eastern Germany has a strong and significant influence on the likelihood of receiving innovation subsidies at all levels. The former German Democratic Republic states continue to have a different innovative framework with much greater governmental activities owing to the absence of larger private innovative actors (Belitz et al. 2010: 4). Furthermore, most of the areas supported by the European convergence targets are situated in eastern Germany, while regional authorities often use these programmes to co-finance. This also influences the other levels, as their programmes and firms often perceive them as regional programmes. ${ }^{7}$ Accordingly, this explains why - at state and European level - firms are less likely to be supported firms in states that pay money into the German federal fiscal system: these five states had hardly any convergence areas in 2005-2007, ${ }^{8}$ apart from North Rhine-Westphalia.

I can negate the easier access to innovation support for firms with a regional market focus for the state and federal level, whereas only the regressions for the European level show a stronger support for regionally focused firms. Therefore, hypothesis 3 can be rejected aside from the European level, which is somewhat surprising. Possible reasons can be found in the selection process and its consequences, whereby 'cream skimming' (Radicic and Pugh 2013: 1), 'cherry picking to identify success stories' (Radicic and Pugh 2013: 20) or a 'picking the winner

\footnotetext{
7 Oral explanation by the ZEW.

8 The donor states were Bavaria, Baden-Wuerttemberg, Hamburg, Hesse and North Rhine-Westphalia.
} 
approach' (Cantner and Kösters 2012: 932-3) might more strongly influence the regional and national level. The pressure to produce success stories is higher within Germany, where voters observe the effects more easily than at the European level. This fact helps to explain the high odds ratio and significance of the dependency of other levels of support, whereby successful firms enjoy easier access at the other levels when being successful at one level.

The fourth hypothesis cannot be rejected, particularly if all three finance variables are considered together: while the effect of a single variable might differ at the three levels, evidence shows that expenditure on $R \& D$, regular innovation activities and higher educated employees have a positive influence, although the continuity of innovative activities is not significant at the state level. Furthermore, the additional regression on path dependency clearly shows - for all three levels - a strong influence of past access to innovation subsidies of the same support level. For this reason, I consider that path dependency influences the reception of public innovation subsidies.

Given that supported firms are not significantly more competitive if they are supported at the state or European level, hypothesis 5 has to be partially rejected. At the federal level in Germany, public support reaches firms, subsequently increasing their turnover and return on sales; however, neither indicators show any clear results for the other two levels. Consequently, the empirical results question the effectiveness of innovation support at the state and European level, especially as the results for turnover and return on sales at both levels are different and incoherent. While a more detailed approach like Atkinson (1991) is impossible for Germany due to the lack of state level data, a comparative approach between European countries is possible. As mentioned earlier, the causality is unclear for the federal level, whereby it is possible that only the firms with a higher probability of increased turnover and return on sales are selected for federal programmes.

The broader German approach with an innovation policy framework at the state, federal and European level reaches for wider variety of firms, which is in line with the general findings of Fernández-Ribas (2009) for Spain. In addition, similar firms with higher innovation barriers have easier access to regional programmes compared with other levels.

However, with strong path dependency, the partially proven danger of 'cream skimming', the lesser regional focus of state programmes, different frameworks and little positive impact on the competitiveness of firms, further research and policy changes have to be undertaken.

A comparative study on different federal and non-federal countries and their respective innovation frameworks can be fruitful, particularly because evidence concerning the effectiveness of European level programmes and decentralized structures is currently lacking. Further output-oriented analysis of the innovative support measures in Germany or other 
European countries and a matching between participating and non-participating firms can help to reduce the gap in empirical findings regarding the innovation framework in Europe.

Policy makers in Germany should be concerned about the unclear results regarding the effectiveness of innovative support at the state and European level. As Atkinson (1991) shows for the USA, a better evaluation of the targets, effectiveness and efficiency of the innovation support framework is necessary. The findings in this paper show that regarding turnover and return on sales as indicators for effectiveness, only the federal level in Germany reaches these standards. This finding supports the activities of countries such as Switzerland, which concentrate innovation support at the federal level, while they at least raise doubts about the effectiveness gains of federalism. Before reacting at the other two levels, other output indicators for effectiveness of innovation support have to be analysed and further research is necessary. Concerning the support of small- and medium-sized firms, none of the different political levels supports these firms as planned. ${ }^{9}$ Only the state level manages at least not to cause disadvantages for SMEs. It is necessary to admit that the likelihood of being supported is higher with a higher number of innovation projects within a firm. Therefore, an underestimation of the likelihood of SME support might cause stronger effects. Nonetheless, the difference between the three support levels clearly marks the necessity for policy makers to react.

Additionally, the partial rejection of a regional market focus further emphasizes the importance of evaluating the selection process of supported firms. When selection processes become 'perverse' (Radicic and Pugh 2013: 18) regarding their impact and when subsidies for randomly chosen firms would have a higher impact than those really chosen, policy-makers have to change the selection processes.

Another critical point is path dependency, whereby firms that have previously been supported are much more likely to be supported in the future. If this is only the case due to regular innovative activities, criticism might not be relevant. However, this effect possibly suggests that programmes exclude new firms and that they face higher barriers to accessing innovation support. Given that Fernández-Ribas (2009) also mentions this problem, German politicians should tackle this problem urgently.

The evidence concerning the issue whether federal structures in Germany foster or reduce innovations has two sides. For instance, all three levels of the German public innovation support framework reach firms with different characteristics, suggesting that federalism fosters

\footnotetext{
${ }^{9}$ All political levels claim to support mainly small and medium-sized enterprises in Germany. Compare for instance Kulicke et al. (2010).
} 
innovation, whereby regional programmes create lower barriers for innovative firms to gain innovation subsidies. However, by contrast, effectiveness is higher at the federal level, which indicates problems of a federal innovation policy framework. Accordingly, measures to increase effectiveness should be introduced to reduce this effect, considering other factors like path dependency or the selection process as problems that innovation support faces at all three levels.

The favourability of a federal system depends upon the preferences, whereby the German society tends to focus on reducing barriers to accessing innovation support because this is a main goal for all innovation programmes.

Nonetheless, while gains for smaller firms in a federal system might be evident, no such gains exist regarding the effectiveness of innovation support. 


\section{Acknowledgements}

Thanks to the ZEW and especially Dr. Sandra Gottschalk for the access to the data of the MIP in Mannheim, as well as to Prof. Dr. Kilian Bizer and Prof. Dr. Markus Spiwoks and the fellow PhDstudents for their input during a seminar at the Georg-August-University in Göttingen. Moreover, thanks to the participants of the EuSPRI and the DRUID conferences for their remarks. Additionally, I am grateful to all those who checked this paper for linguistic errors. 


\section{Appendix}

Table A1: Attributes of supported firms with time lags for earlier support (logistic regressions, logit)

\begin{tabular}{|c|c|c|c|c|c|c|c|c|c|}
\hline & \multicolumn{3}{|c|}{ Regional level (suppst) } & \multicolumn{3}{|c|}{ National level (suppfe) } & \multicolumn{3}{|c|}{ European level (suppeu) } \\
\hline & Coef. & & Std. Err. & Coef. & & Std. Err. & Coef. & & Std. Err. \\
\hline suppst & & & & 0.4911 & & 0.3470 & 1.3640 & $* * *$ & 0.4933 \\
\hline suppfe & 0.8624 & $* * *$ & 0.3252 & & & & 1.3545 & $* * *$ & 0.4580 \\
\hline suppeu & 1.4223 & $* * *$ & 0.4057 & 1.5936 & $* * *$ & 0.4461 & & & \\
\hline sme & -0.4262 & & 0.4105 & 0.4465 & & 0.3378 & 0.0081 & & 0.5282 \\
\hline Inrdexp & 0.3774 & ** & 0.1747 & -0.0104 & & 0.1349 & 0.2157 & & 0.2727 \\
\hline highedu & 0.0004 & & 0.0059 & 0.0113 & ** & 0.0054 & 0.0199 & $* * *$ & 0.0078 \\
\hline regularly & -0.2845 & & 0.3527 & 0.2943 & & 0.3367 & 1.8204 & ** & 0.7255 \\
\hline mshar & -0.0016 & & 0.0059 & -0.0010 & & 0.0052 & -0.0155 & * & 0.0090 \\
\hline national & 1.0964 & * & 0.6304 & 0.1265 & & 0.5213 & -1.3682 & & 0.8360 \\
\hline international & 1.3491 & ** & 0.6699 & 0.1609 & & 0.5548 & -0.8684 & & 0.8699 \\
\hline qualcomp & -0.1785 & & 0.3551 & 0.3661 & & 0.3345 & -0.9800 & * & 0.5353 \\
\hline east & 1.1561 & $* * *$ & 0.4453 & 0.7253 & & 0.4464 & -0.8051 & & 0.6457 \\
\hline donor & -0.5114 & & 0.4432 & -0.1079 & & 0.4219 & 0.1652 & & 0.6062 \\
\hline suppst05 & 1.7346 & $* \star *$ & 0.3035 & 2.5687 & $* \star *$ & 0.2854 & 3.6153 & $* \star *$ & 0.4889 \\
\hline _cons & -2.7027 & $\star \star \star *$ & 0.9618 & -3.4829 & & 0.8693 & -3.7010 & ** & 1.5108 \\
\hline LR chi² (13) & 155.27 & & & 233.37 & & & 180.48 & & \\
\hline Prob > chi ${ }^{2}$ & 0.0000 & & & 0.0000 & & & 0.0000 & & \\
\hline Pseudo $R^{2}$ & 0.3244 & & & 0.3874 & & & 0.5136 & & \\
\hline
\end{tabular}

Data: ZEW MIP 2007; Notes: Calculated with Stata (2014); ${ }^{* \star *}$ denotes significance at $1 \%$ level; ${ }^{* *}$ at $5 \%$ level; * at $10 \%$ level 
Table A2: Attributes of supported firms (logistic regressions with robust standard errors, logit)

\begin{tabular}{|c|c|c|c|c|c|c|c|c|c|}
\hline & \multicolumn{3}{|c|}{ Regional level (suppst) } & \multicolumn{3}{|c|}{ National level (suppfe) } & \multicolumn{3}{|c|}{ European level (suppeu) } \\
\hline & Coef. & & $\begin{array}{l}\text { Rob. } \\
\text { Std. Err. }\end{array}$ & Coef. & & $\begin{array}{l}\text { Rob. } \\
\text { Std. Err. }\end{array}$ & Coef. & & $\begin{array}{l}\text { Rob. } \\
\text { Std. Err. }\end{array}$ \\
\hline suppst & & & & 1.3399 & $* \star \star$ & 0.1795 & 1.2281 & $* * *$ & 0.2356 \\
\hline suppfe & 1.3413 & $* * *$ & 0.1790 & & & & 1.5767 & $* * *$ & 0.2352 \\
\hline suppeu & 1.1995 & $* * *$ & 0.2324 & 1.5691 & $* * *$ & 0.2384 & & & \\
\hline sme & 0.0231 & & 0.2105 & -0.1782 & & 0.1955 & -0.5227 & * & 0.2827 \\
\hline Inrdexp & 0.1501 & * & 0.0790 & 0.0511 & & 0.0720 & 0.3548 & $* * *$ & 0.1278 \\
\hline highedu & 0.0036 & & 0.0034 & 0.0164 & $* * *$ & 0.0028 & 0.0148 & $* * *$ & 0.0038 \\
\hline regularly & 0.1953 & & 0.2070 & 0.6695 & $* * *$ & 0.1893 & 0.5823 & ** & 0.2962 \\
\hline mshare & -0.0023 & & 0.0037 & -0.0007 & & 0.0030 & 0.0085 & ** & 0.0036 \\
\hline national & 0.1305 & & 0.3235 & 0.2315 & & 0.2939 & -0.8773 & ** & 0.3728 \\
\hline international & 0.4546 & & 0.3454 & 0.3239 & & 0.3130 & -0.5872 & & 0.3858 \\
\hline qualcomp & 0.2247 & & 0.2279 & 0.4674 & ** & 0.1951 & -0.2083 & & 0.2560 \\
\hline east & 1.3127 & $* * *$ & 0.2568 & 1.1255 & $* * *$ & 0.2445 & -0.7736 & ** & 0.3308 \\
\hline donor & -0.5032 & * & 0.2667 & 0.3086 & & 0.2312 & -0.4855 & * & 0.2813 \\
\hline cons & -2.7018 & $\star * \star$ & 0.4858 & -3.4385 & $* * *$ & 0.5126 & -2.0787 & $\star * \star$ & 0.6297 \\
\hline $\begin{array}{l}\text { Wald chi } \\
\text { (12) }\end{array}$ & 226.41 & & & 229.14 & & & 171.74 & & \\
\hline Prob > chi ${ }^{2}$ & 0.0000 & & & 0.0000 & & & 0.0000 & & \\
\hline Pseudo $R^{2}$ & 0.2462 & & & 0.2282 & & & 0.2408 & & \\
\hline
\end{tabular}

Data: ZEW MIP 2007; Notes: Calculated with Stata (2014); ${ }^{* \star *}$ denotes significance at $1 \%$ level; ${ }^{* *}$ at $5 \%$ level; * at $10 \%$ level 


\section{References}

Ács, Z. J., and Varga, A. (2005), 'Entrepreneurship, agglomeration and technological change', Small Business Economics, 24/3: 323-334

<http://www.springerlink.com/content/xu28gv43m744450m/fulltext.pdf>.

Aerts, K., and Czarnitzki, D. (2004), Using Innovation Survey Data to Evaluate R\&D Policy: The Case of Belgium, ZEW Discussion Paper, No. 04-55 (Mannheim) <ftp://ftp.zew.de/pub/zewdocs/dp/dp0455.pdf>, accessed 11 Mar 2015.

Arrow, K. J. (1962), 'Economic welfare and the allocation of resources for invention', in Universities National Bureau Committee for Economic Research (ed.), The rate and direction of inventive activity. economic and social factors, a conference of the Universities-National Bureau Committee for Economic Research and the Committee on Economic Growth of the Social Science Research Council, 609-25.

Atkinson, R. D. (1991), 'Innovation policy making in a federalist system: Lessons from the states for U.S. federal innovation policy making', Research Policy, 20/6: 559-577 <http://www.sciencedirect.com/science/article/pii/004873339190046S>.

Becker, L. (2012), 'Innovation subsidies in a federal system. Innovation policy at different political levels in Germany', in GSTF and M. Hunter (eds.), Proceedings of the 2nd annual International Conference on Innovation and Entrepreneurship (IE 2012) (Singapore: GSTF), 59-64.

Belitz, H., Eickelpasch, A., and Lejpras, A. (2010), 'Technologieoffene Förderung - Zentrale Stütze der Industrieforschung in Ostdeutschland', Wochenbericht des DIW Berlin, 77/51-52: 210.

Blankart, C. B. (2006), Öffentliche Finanzen in der Demokratie: Eine Einführung in die Finanzwissenschaft (Vahlens Handbücher der Wirtschafts- und Sozialwissenschaften; 6., völlig überarb. Aufl., München: Vahlen) <http://www.gbv.de/dms/ilmenau/toc/502985518blank.PDF>.

Brouwer, M. T. (2000), 'Entrepreneurship and uncertainty: innovation and competition among the many', Small Business Economics, 15/2: 149-160 <http://www.springerlink.com/content/n128n516370564j8/fulltext.pdf>.

Busom, I. (2000), 'An Empirical Evaluation of the Effects of R\&D Subsidies', Economics of Innovation \& New Technology, 9/2: 111-149 $<$ http://search.ebscohost.com/login.aspx?direct=true\&db=buh\&AN=3977234\&site=ehost-live $>$.

Busom, I., and Fernández-Ribas, A. (2007), 'Do R\&D Programs of Different Government Levels Overlap in the European Union?', in , Science, Technology and Innovation Policy, 1-5.

Cantner, U., and Kösters, S. (2012), 'Picking the winner? Empirical evidence on the targeting of R\&D subsidies to start-ups', Small Business Economics, 39/4: 921-936.

Czarnitzki, D., and Fier, A. (2002), 'Do Innovation Subsidies Crowd Out Private Investment? Evidence from the German Service Sector', Applied Economics Quarterly (Konjunkturpolitik), 48/1: 1-25 <http://econstor.eu/bitstream/10419/24802/1/dp0204.pdf>.

Czarnitzki, D., Hanel, P., and Rosa, J. M. (2011), 'Evaluating the impact of R\&D tax credits on innovation. A microeconomic study on Canadian firms', Research Policy, 40/2: 217-229.

Duguet, E. (2004), 'Are R\&D subsidies a substitute or a complement to privately funded R\&D ? An econometric analysis at the firm level', Revue d'Economie Politique, 114/2: 245-274 $<$ http://www.cairn.info/revue-d-economie-politique-2004-2.htm>.

Erlei, M., Leschke, M., and Sauerland, D. (2007), Neue Institutionenökonomik (2., überarb. und erw. Aufl., Stuttgart: Schäffer-Poeschel) <http://deposit.d-nb.de/cgibin/dokserv?id=2890495\&prov=M\&dok_var=1\&dok_ext=htm>.

Feld, L. P. (2007), 'Zur ökonomischen Theorie des Föderalismus. Eine prozeßorientierte Sicht', in K. Heine and W. Kerber (eds.), Zentralität und Dezentralität von Regulierung in Europa (Schriften zu Ordnungsfragen der Wirtschaft, 83, Stuttgart: Lucius \& Lucius), 31-54. 
Fernández-Ribas, A. (2009), 'Public support to private innovation in multi-level governance systems: an empirical investigation', Science and Public Policy, 36: 457-467 <http://www.ingentaconnect.com/content/beech/spp/2009/00000036/00000006/art00004 http://dx.doi.org/10.3152/030234209X460953>.

Fier, A., and Czarnitzki, D. (2005), 'Zum Stand der empirischen Wirkungsanalyse der öffentlichen Innovations- und Forschungsförderung' <http://www.zew.de/de/publikationen/evaluationinno/ZEW_Ueberblick_Wirkungsanalyse.pdf>, updated 2005, accessed 11 Mar 2015.

Görg, H., and Strobl, E. (2007), 'The Effect of R\&D Subsidies on Private R\&D', Economica, 74/294: 215-234 <http://dx.doi.org/10.1111/j.1468-0335.2006.00547.x>.

Grenzmann, C., Kladroba, A., and Niehof, B. (2010), 'The R\&D survey of the German business enterprise sector', Schmollers Jahrbuch, 130/3: 381-391.

Griliches, Z. (1992), 'The Search for R\&D Spillovers', The Scandinavian Journal of Economics, 94: 29-47 <http://www.jstor.org/stable/3440244>.

Grossman, G. M., Helpman, and Elhanan (1994), 'Endogenous Innovation in the Theory of Growth', The Journal of Economic Perspectives, , 8/1: 23-44 <http://www.jstor.org/stable/i337439>.

Grossman, G. M., and Helpman, E. (1991), Innovation and growth in the global economy (Cambridge, Mass: MIT Press).

Hall, B., and van Reenen, J. (2000), 'How effective are fiscal incentives for R\&D? A review of the evidence', Research Policy, 29/4 - 5: 449-469.

Hausner, K. H. (2005), 'Die Ökonomische Theorie des Föderalismus', Wirtschaftsdienst, 85/1: 55-60.

Konings, J., and Torfs, W. (2011), 'Fiscal Federalism, Tax Competition and Economic Agglomeration', in Flemish Department of Finance and Budget (ed.), Fiscal Federalism in the European Union. EU Presidency Seminar (Brussels: Larcier), 35-56.

Krohmer, O. (2010), 'Zur Verdrängungswirkung staatlicher FuE-Förderung', ifo Dresden berichtet, 17/4: 49-51.

Kulicke, M., Hufnagl, M., Brandt, T. et al. (2010), Evaluierung des Programmstarts und der Durchführung des "Zentralen Innovationsprogramms Mittelstand (ZIM)": Endbericht (Karlsruhe/Berlin).

Lach, S. (2002), 'Do R\&D Subsidies Stimulate or Displace Private R\&D? Evidence from Israel', The Journal of Industrial Economics, , 50/4: 369-390 <http://www.jstor.org/stable/3569779>.

Levine, R. (1997), 'Financial Development and Economic Growth: Views and Agenda', Journal of Economic Literature, 35/2: 688-726 <http://www.jstor.org/stable/2729790?origin=JSTORpdf>.

Levy, D. M. (1990), 'Estimating the impact of government R\&D', Economics Letters, 32/2: 169173.

Lijphart, A. (2012), Patterns of democracy: Government forms and performance in thirty-six countries (2nd edn., New Haven: Yale University Press).

Loury, G. C. (1979), 'Market structure and innovation', The quarterly journal of economics, 93/3: 395-410.

Nelson, R. R. (1959), 'The Simple Economics of Basic Scientific Research', The Journal of Political Economy,, 67/3: 297-306 <http://www.jstor.org/stable/1827448?origin=JSTOR-pdf>. Neumann, M. (1971), 'Zur ökonomischen Theorie des Föderalismus', Kyklos, 24/3: 493-510.

Oates, W. E. (1972), Fiscal federalism (The Harbrace series in business and economics, New York, NY: Harcourt Brace Jovanovich).

Oates, W. E. (2005), 'Toward a second-generation theory of fiscal federalism', International tax and public finance, 12/4: 349-373.

OECD (2011), Regions and innovation policy (OECD reviews of regional innovation, Paris: OECD Publ.). 
Pitlik, H. (1997), Politische Ökonomie des Föderalismus: Föderative Kompetenzverteilung im Lichte der konstitutionellen Ökonomik, Univ., Diss.--Hohenheim, 1996. (Hohenheimer volkswirtschaftliche Schriften, 26, Frankfurt am Main: Lang) $<\mathrm{http}: / /$ www.gbv.de/dms/hbz/toc/ht007497397.pdf>.

Radicic, D., and Pugh, G. (2013), 'The impact of innovation support programmes on SME innovation in traditional manufacturing industries. an evaluation for seven EU regions', in DRUID society (ed.), Conference Proceedings DRUID Academy 2013 (online) $<$ http://druid8.sit.aau.dk/acc_papers/bqon0p6k7nppx07f6gk96qmm0cte.pdf>, accessed 15 Oct 2014.

Rothgang, M., and Dürig, W. (2009), 'Innovative und forschende Unternehmen in Deutschland', WiSt Wirtschaftswissenschaftliches Studium, 38/5: 267-270.

Schmalholz, H. (2005), 'Steuerungsmöglichkeiten von Innovationspolitik in den Bundesländern: Das Beispiel Sachsen', ifo Dresden berichtet, 12/5: 18-26.

Schumpeter, J. A. (2008), Capitalism, socialism and democracy (3rd edn., New York, NY [u. a.]: Harper Perennial Modern Classics), first pub. 1942.

Stata (2014), Stata (StataCorp LP).

Thomä, J., and Bizer, K. (2013), 'To protect or not to protect? Modes of appropriability in the small enterprise sector', Research Policy, 42/1: 35-49.

Tiebout, C. M. (1956), 'A pure theory of local expenditures', Journal of Political Economy, 64/5: 416-424.

Wallsten, S. J. (2000), 'The effects of government-industry R\&D programs on private R\&D: the case of the Small Business Innovation Research program', RAND Journal of Economics (RAND Journal of Economics), 31/1: 82-100 $<$ http://search.ebscohost.com/login.aspx?direct=true\&db=buh\&AN=3053312\&site=ehost-live > .

Wilson, D., and Souitaris, V. (2002), 'Do Germany's federal and land governments (still) coordinate their innovation policies?', Research Policy, 31/7: 1123-1140.

ZEW, Mannheim Innovation Panel (MIP) (Mannheim). 
Kapitel 3

\section{Federalism and innovation support for small and medium-sized enterprises}

\section{Empirical evidence in Europe}

(mit Kilian Bizer)

Eingereicht bei Research Policy

cege Discussion Paper No. 245 


\section{Abstract}

Private innovative activities receive public innovation support from different political levels. Few studies have empirically evaluated the influence of political systems on the reception of public innovation support and no other studies have evaluated innovation support across Europe with CIS data.

This paper analyses the differences between federal, semi-federal and centralist political systems with CIS data from sixteen European countries. The results show that regional programmes in federal and semi-federal countries reach firms with barriers to innovate, such as small and medium-sized enterprises, while other programmes only claim to reach them. Federal and semifederal countries therefore support a broader variety of firms compared with centralist countries. European support reaches SMEs better in centralist countries compared with federal and semifederal countries. Regular and higher expenditure on innovative activities shows a positive influence on the reception of support in all countries, while indicators such as market focus vary between countries and political levels. Regional programmes focus more strongly on companies with a regional market focus, which can be seen as another barrier to innovation. As a policy implication, the paper implies that barriers to innovation can be reduced by a decentralized innovation framework with stronger regional programmes.

\section{Key Words}

Innovation, innovation support, SME, Europe, federalism, decentralization

\section{JEL Classification}

O31, O38, H77, H71 


\section{Introduction}

Creativity and innovations are key factors of economic growth and development, as Schumpeter (2008) was one of the first economists to recognise. Fostering innovation and thus indirectly economic growth leads governments to support private innovative activities. Governments offer public support either directly via subsidies or indirectly via tax credits. State aid to research, development and innovation comprised an average of 12.5 per cent of total state aid in the European Union ${ }^{1}$ in 2008.

This figure prompts the question whether the money is well spent. Many studies analyse the effectiveness of public innovation support, with the majority considering the policy framework within a country to be homogenous. Nonetheless, homogeneity is questionable, especially in federal countries. In countries such as Germany or Belgium or in semi-federal countries, such as Spain or Finland, the regional level strongly influences the innovation framework; for instance, public support in the Basque region might be different than in Valladolid, while Bavaria might offer different subsidies to Saxony.

The purpose of this paper is to evaluate public innovation support, in particular with regard to the influence of federalism.

Innovation is more than research and development (R\&D). Accordingly, we use the definition of the Oslo Manual (OECD, 1997, pp. 30-31), which includes the application of research results in the products of the firms. Additionally, it incorporates the implementation of findings that are new not to the entire market but rather to the firm. This definition of innovation is broader than R\&D, ${ }^{2}$ although R\&D forms the core of innovative activities.

Firms face barriers to innovate, given that the results of research and innovations are uncertain and might diffuse to other firms. The barriers to innovate hit smaller companies harder as they have fewer opportunities to diversify their risks. Therefore, most public support programmes focus on small and medium-sized enterprises (SMEs), although innovation theory is unclear about whether smaller (Audretsch, 2001, p. 6; Arrow, 1962) or larger firms (Schumpeter, 2008, p. 106) are the main engines for innovation in an economy.

Studies have rarely analysed the effects and the rationale behind programmes of different political levels (see Vonortas et al., 2007). The very few studies that analyse the different levels of public support in federal and semi-federal countries show differences especially concerning firms that face barriers to innovate. For instance, Fernández-Ribas (2009, pp. 464-465) shows for Catalonia

\footnotetext{
${ }^{1}$ Own calculations with data from European Commission (2013).

2 R\&D is defined in the Frascati Manual: OECD (2002).
} 
that regional programmes better reach firms with 'obstacles to innovate', which is in line with the findings from Becker (2013) for SMEs in Germany. Blanes and Busom (2004, p. 1474) also find that regional programmes 'reach on average smaller firms' in Spain. Atkinson (1991) describes differences between different states in the USA.

We analyse whether these findings are country-specific for Germany and Spain or whether similar results can be found in other federal and semi-federal countries by using country-specific data and data at the European level from Eurostat's Community Innovation Survey (CIS microdata). We match supported and not-supported companies through propensity score matching with a probit estimation as a structural equation to test for characteristics of supported firms.

In the next section, we describe the existing literature concerning innovation policy and federalism both theoretically and empirically. The literature leads to six hypotheses, which are formulated in the third section. In our fourth section, we discuss the data and methods applied in our empirical work before describing the results in section five. The sixth and final section draws conclusions concerning the effect of federal structures on innovation support.

\section{Literature review}

Historically, Brouwer (2000, p. 149) claims that innovative capacities started growing with capitalism. Moreover, Grossman et al. (1994, p. 32) emphasize the importance of innovations for economic growth from economic history. These historic findings show the importance of innovation policy and its framework. Section 2.1 looks at the justification for public innovation support and gives an overview of empirical findings. Section 2.2 briefly reflects theories of federalism followed by a classification of federal, semi-federal and centralist systems in Europe.

\subsection{Justification for public innovation support}

Private firms invest in innovation if they expect to make profit from it (Grossman et al., 1994, p. 27; Griliches, 1992, p. 29). However, it is questionable whether this private profit is as high as the profit to society. Studies from Wallsten (2000, p. 83), Klette et al. (2000, p. 486), Blanes and Busom (2004, p. 1459) or Görg and Strobl (2007, p. 1) emphasize the point of higher social returns of R\&D or innovation. A more detailed study by Lang (2009, p. 1439) shows that social returns are higher, and that private returns do not occur immediately but rather with a time-lag of approximately two years. Hall et al. (2009, p. 17) and Bohnstedt (2014, p. 13) provide similar results. However, the delayed influence of innovative activities is only one aspect of market failure that causes the socially suboptimal level of private investment.

Innovations can be categorized - at least partially - as a public good, as stated by Arrow (1962). Innovation is a non-excludable and non-rivalrous good in a completely free market (Griliches, 
1992, p. 31). ${ }^{3}$ When one firm innovates, another firm might recognize this and implement the same innovation. Although the latter firm does not have to pay the costs of innovating, it benefits from its advantages. The implementation of another firm's innovation creates social gains from spillovers or - put differently - positive externalities, although it reduces companies' willingness to innovate. This problem is described in the literature (Nelson, 1959, pp. 305-306; Beaudry and Breschi, 2003, pp. 337-338; Griliches, 1992, p. 31). Duguet (2004, pp. 246-247) mentions intellectual property rights (IPR) as a solution to the problem of non-excludability.

Additionally, firms face uncertainty with regard to the success of innovation as well as the success of securing the benefits (see Arrow, 1962, pp. 609-610; Brouwer, 2000, p. 150; Grossman et al., 1994, pp. 37-38). For example, firms do not know whether one of their high-skilled employees with knowledge of an innovation project will join another company. Additionally, 'no firm can be sure when any of its rivals' R\&D efforts will be successful' (Loury, 1979, p. 397). This indicates further uncertainty at the market level, which Czarnitzki and Toole (2008, p. 9) support empirically. Clausen (2009, p. 242) ascertains that R\&D 'close to the market' faces less uncertainty than that 'far from the market'.

Most of the uncertainties affect SMEs more strongly than larger companies. Due to the higher wages in larger companies (see Brown et al., 1990, pp. 88-89), SMEs' employees can more easily be attracted to leave the company. Due to the lower possibility of diversifying their risks (see Levine, 1997, p. 694), financial restraints and the effect of uncertainty affect smaller firms more intensely, or as Czarnitzki and Toole (2008, p. 10) state: 'large firms respond less to market uncertainty than small firms.' Hong et al. (2012, p. 429) describe that medium-sized companies in particular face such disadvantages, as an inverted U-shape of innovativeness related to firm size can be found. These results place SMEs at the focus of many governmental programmes fostering innovation.

To reduce the problem of uncertainty, subsidies (or tax credits) are granted. Hussinger (2008, pp. 744-745) argues with Czarnitzki and Toole (2008) that subsidies reduce uncertainty, while Czarnitzki et al. (2011) and Cerulli (2010, pp. 423-424) describe other market imperfections, such as financial restraints.

For all these causes, Arrow (1962, pp. 622-625) claims that measures of public innovation support are justified. For this reason, the European countries supported private innovative activities with $€ 9.4$ billion of direct aid in 2008 (European Commission, 2013).

Its effectiveness has to be analysed as companies tend to take support measures if available, even if they would have innovated without them (see Blanes and Busom, 2004, p. 1463). Scholars

\footnotetext{
${ }^{3}$ However, this definition as a pure public good is questioned in Cerulli (2010, p. 423).
} 
often measure the effectiveness of support as additionality, with studies examining whether public support induces additional private innovative activities (Cerulli, 2010).

Aerts and Czarnitzki (2004, p. 16) find additionality in Belgium, as well as Duguet (2004, p. 272) in France, while Czarnitzki and Fier (2002, pp. 17-18) find partial additionality for public innovation support in Germany. Later in Fier and Czarnitzki (2005, p. 4), the authors show that one euro of public support induces another $€ 0.28$ of private spending. Hussinger (2008, p. 743) finds even higher additionality as she calculates that one euro of public subsidies leads to one additional euro of private investment. Busom (2000, p. 133) finds additionality for manufacturing firms in Spain, although she cannot completely rule-out a crowding-out effect, whereas González Cerdeira and Pazó Martínez (2008, p. 384) do not show even partial crowding-out in Spain. Görg and Strobl (2007, p. 231) show that additionality can be found especially for smaller grants in Ireland. However, they generally find no evidence of crowding-out independent of grant size.

A survey by Radicic and Pugh (2013, p. 1) ascertains a 'cream-skimming' effect. Accordingly, political actors try to select those companies that can most likely present a success story afterwards. These results are in line with earlier findings from Cantner and Kösters (2012, pp. 932-933) who also show a strategy of 'picking the winner' among public agencies in Thuringia (Germany) to circumvent information problems.

In contrast to the EU, where the majority of studies show at least partial additionality, evidence from the USA is less clear. Levy (1990, p. 172) shows that programmes vary in different states and crowding-out can only sometimes be found. Wallsten (2000, pp. 97-98) finds that the US national innovation grants 'crowd out firm-financed R\&D spending dollar for dollar', although David et al. (2000) show partial complementarity. Koga (2005, p. 60) finds complementarity for Japanese innovation support. For Israel, Lach (2002, p. 389) analyses innovation support and finds that the substititutionality depends on the firm size. He cannot completely rule out a crowding-out, although he shows that the risk is much lower for smaller companies.

For our analysis of innovation support, the characteristics of firms supported are important especially the firm size. In terms of size (measured in his study by sales), Duguet (2004, p. 267) finds that higher sales have a positive influence on the probability of receiving a subsidy. The probability increases with the ratio of $R \& D$ to sales, the debt ratio and the reception of public support in the past.

What all of the aforementioned studies mentioned share in common is that they treat innovation support within a country homogenously. By contrast, the following scholars analyse different political levels - namely regional, national or European support - separately.

While Wilson and Souitaris (2002, pp. 1135-1136) only focus on the coordination between different federal levels and question whether coordination exists, Becker (2012, p. 62) finds 
differences between the three levels of public support in Germany. One result is that SMEs have a lower probability of receiving national and European support in Germany. For the regional level, the coefficient is not significant but remains negative, albeit closer to zero. Becker (2013) finds that regional differences in Germany have a significant effect on the likelihood of receiving public support and that SMEs face obstacles, especially at the European level.

Similar to Wilson and Souitaris (2002), Vitola (2014, p. 9) analyses coordination, governmental structures as well as regional differences around the Baltic Sea (Nordic and Baltic countries). She finds a high amount of coordination among policy-makers and a low risk of overlapping programmes from different political levels (Vitola, 2014, p. 13).

Blanes and Busom (2004, p. 1474) differentiate between all three levels of support in Spain and find a regional focus on smaller companies. Also analysing Spanish CIS data, Busom and Fernández-Ribas (2007, p. 3) focus on the differences between national and European level support: while national programmes focus more strongly on research intensity and international patenting, European programmes show a focus on export intensity and foreign markets in Spain. In general, they find complementarity between the two levels of innovation support. FernándezRibas (2009, pp. 464-465) finds similar results for Catalan firms, analysing all three levels of support. Accordingly, firms 'facing major obstacles' are more likely to receive regional support, while 'domestic firms with patenting experience, as well as [...] firms operating in high knowledge content industries', receive national support more easily.

In sum, existing literature suggests at least partial additionality of public R\&D. Differences between the characteristics of supported firms exist between innovation support programmes from different political levels, whereby smaller companies are better reached by regional programmes - at least in Spain and Germany. 
Table 1: R\&D\&I aid in 2008 (absolute in million $€$ on R\&D\&I aid, relative as share in \% to overall state aid)

\begin{tabular}{lrr}
\hline \multirow{2}{*}{ Country } & Absolute & Relative \\
\cline { 2 - 3 } EU-27 & $9,437.0$ & $12.50 \%$ \\
\hline Bulgaria & 6.6 & $2.89 \%$ \\
Czech Republic & 211.0 & $14.74 \%$ \\
Estonia & 3.4 & $7.62 \%$ \\
Finland & 274.4 & $12.30 \%$ \\
France & $1,857.8$ & $13.89 \%$ \\
Germany & $2,413.2$ & $14.30 \%$ \\
Hungary & 73.3 & $3.37 \%$ \\
Latvia & 0.7 & $0.52 \%$ \\
Lithuania & 0.1 & $0.05 \%$ \\
Luxemburg & 22.8 & $26.41 \%$ \\
The Netherlands & 291.7 & $11.87 \%$ \\
Portugal & 18.5 & $1.14 \%$ \\
Romania & 64.2 & $7.39 \%$ \\
Slovak Republic & 4.0 & $1.02 \%$ \\
Slovenia & 22.0 & $8.61 \%$ \\
Spain & 910.9 & $16.17 \%$ \\
\hline
\end{tabular}

Data: European Commission (2013), own calculations for 16 countries.

\section{$2.2 \quad$ Federalism operationalized}

Tiebout (1956, p. 418) states that local governments provide many public goods in a decentralized manner, whereby differences between cost structures across jurisdictions influence the allocation. Regarding the allocation, he also describes the problem of externalities and free-riding jurisdictions that profit from spillovers of the neighbouring governments. Closely analysing which goods should be provided at which level, Oates (1972, pp. 9-13) shows that pure public goods are better allocated by the national level. By contrast, the decentralized regional levels should allocate goods when different preferences, mobility and willingness to pay taxes exist.

With regard to innovation policy, Loury (1979, p. 395) shows for companies that 'a degree of concentration intermediate between pure monopoly and atomistic (perfect) competition [...] is best in terms of R\&D performance'. This finding for the market structure can also link to federal structures in the field of public innovation policy, whereby decentralized learning processes lead to more successes (see Saam and Kerber, 2013).

Montmartin (2011, p. 3) describes the problem of spatial externalities and free-riding for the field of innovation policy. These problems underline the discussion of Busom and Fernández-Ribas (2007, p. 1) concerning whether different jurisdictions 'lead to a globally efficient allocation of R\&D and do not duplicate efforts', which we want to analyse in further detail. 
Regarding public goods in general, the problem of spatial externalities should not lead automatically to a centralized provision according to Feld (2007, p. 32), but rather to an analysis concerning the level at which the good is better provided. By contrast, Konings and Torfs (2011, pp. 38-39) show the efficiency losses due to missing economies of scale and externalities in a decentralized system.

Highlighting advantages and disadvantages of federal and decentralized structures, Hayek (1948) or Musgrave (1959) outline different fields that can be handled federally.

Differences in innovation programmes between states are linked to the theory of innovation, as described in Atkinson (1991, p. 563). From a more theoretical approach Edler and Kuhlmann (2008, p. 274) claim that the German system as a whole suffers disadvantages due to less coordinated policy measures. Wilson and Souitaris (2002, p. 1125) describe the problem of overlap between political systems in Germany, which Vitola (2014, p. 9) does not find around the Baltic Sea. Nonetheless, regional jurisdictions in a federal state might try to use similar approaches and target groups. This emphasizes the necessity of coordination efforts in the field of innovation policy (see Braun, 2008).

In addition to the theory of federalism, multi-level approaches have become increasingly important, especially for the European level; for instance, Stein and Turkewitsch (2010, p. 3) emphasize that 'federalism and multi-level governance share some important characteristics'. However, they point out that multi-level approaches focus particularly on supranational institutions like the EU.

All these findings lead to a separation between national, regional and EU-level support for innovative activities (Blanes and Busom, 2004, p. 1460; OECD, 2011, p. 76). Furthermore, in recent years the influence of regional governments has grown (see Fernández-Ribas, 2009, p. 457; OECD, 2011, p. 31).

This development to regional structures also influences Europe: the EU comprises a variety of countries with different political and historical backgrounds. Therefore, we find a heterogeneity of political systems all over Europe. Germany, the largest EU Member State, is a federal country, while France, the second largest nation, can clearly be marked as a centralist country. Moreover, Portugal is centralist while Spain is semi-federal, and so on.

Blume and Voigt (2011, p. 241) raise the point that a distinction between federalism and decentralization has to be made: in a federal system, the division of powers is created 'bottomup', while the national level creates the division 'top-down' in a decentralized yet centralist system. Lijphart (2012, pp. 174-186) provides an overview of different political systems related to federalism and decentralization. As shown in Table 1, Lijphart (2012) creates an index of federalism for (among others) European countries. He distinguishes the degree of federalism (as the autonomy of a jurisdiction in its decisions) as well as decentralization (as the degree of 
competencies given to a jurisdiction at a lower level). ${ }^{4}$ Given that Lijphart does not categorize most eastern European countries, Roberts (2006, pp. 43-44) adds this aspect and classifies all of these countries as centralist and centralized according to Lijphart's index. In this paper, we aggregate the three categories between federal/decentralized and centralist/centralized to semi-federal. ${ }^{5}$ These countries usually have mixed structures. As an example, Scandinavian countries can be generally seen as centralist countries, but they also have decentralized structures regarding innovation support (see Vitola, 2014, p. 7).

While a larger number of centralist and centralized countries exist, federal and semi-federal countries are fewer but a non-negligible factor in Europe. It is important to mention that the degree of decentralization of innovation support might vary compared with federalism in general; for example, Switzerland focuses its innovation support at the national level, while regional programmes also exist in almost all centralized countries. Indeed, only some smaller countries like the Baltic countries or the Slovak Republic show hardly any regional programmes.

Generally, the different innovation frameworks in Europe are described in (OECD, 2011).

In summary, in terms of the political structure in Europe, most countries have a centralized system, which nonetheless offers - to a lesser extent - regional support programmes, while there are only two clear federal countries, especially in the field of innovation, and several semi-federal countries in between.

\footnotetext{
${ }^{4}$ For detailed distinctions between both categories and the primary and secondary characteristics, see Lijphart (2012, p. 176).

5 These categories aggregated are centralized but federal countries, semi-federal countries and decentralized but centralist countries.
} 
Table 2: Categorization of countries in the EU

\begin{tabular}{|c|c|c|}
\hline Federal and decentralized & Semi-federal & Centralist and centralized \\
\hline $\begin{array}{ll}\text { - } & \text { Belgium (after 1993) } \\
\text { - } & \text { Germany }\end{array}$ & $\begin{array}{ll}\text { - } & \text { Austria } \\
\text { - } & \text { Denmark } \\
\text { - } & \text { Finland } \\
\text { - } & \text { The Netherlands } \\
\text { - } & \text { Spain } \\
\text { - } & \text { Sweden } \\
\text { - } & \text { United Kingdom (after 1998) }\end{array}$ & $\begin{array}{ll}\text { - } & \text { Bulgaria } \\
\text { - } & \text { Czech Republic } \\
\text { - } & \text { Estonia } \\
\text { - } & \text { France } \\
\text { - } & \text { Greece } \\
\text { - } & \text { Hungary } \\
\text { - } & \text { Ireland } \\
\text { - } & \text { Italy } \\
\text { - } & \text { Latvia } \\
\text { - } & \text { Lithuania } \\
\text { - } & \text { Luxembourg } \\
\text { - } & \text { Malta } \\
\text { - } & \text { Portugal } \\
\text { - } & \text { Romania } \\
\text { - } & \text { Slovak Republic } \\
\text { - } & \text { Slovenia }\end{array}$ \\
\hline
\end{tabular}

Notes: Based on Lijphart (2012, p. 178), three categories aggregated to semi-federal, several countries added by Roberts (2006, p. 44), countries included in this study in bold. 


\section{Hypotheses}

The scope of the hypotheses is to test for the effect of political regimes on the likelihood of receiving public innovation support for private innovative activities, as well as the connection to firm characteristics. We combine these fields because firm characteristics are likely to have a strong influence on the likelihood of receiving support, but might be related to political surroundings.

\section{Hypothesis 1: Small and medium-sized enterprises (SMEs) have greater difficulties in securing national and supranational innovation support compared with regional innovation support.}

Support programmes are supposed to reduce barriers to innovate. Classical barriers to innovate are higher for smaller companies, such as risk diversification or excludability and rivalry problems. Moreover, access to capital and knowledge might be more difficult for SMEs, as described in the literature. Programmes should thus prefer smaller companies in theory; indeed, innovation support programmes from all levels claim to reach SMEs as one of their main aims. Small and mediumsized companies should be more strongly supported by the regional level as the theory of federalism more closely links the regional level to the preferences of the jurisdictions, which should be directly influenced by the easier access for smaller companies nearby. Fernández-Ribas (2009, pp. 464-465) finds this effect for Spain.

Hypothesis 1 analyses whether the general aim is reached better at the regional level in Europe. We expect a positive and higher coefficient for SMEs at the regional funding level and fewer or no effects at the national and supranational level.

\section{Hypothesis 2: Countries with a more decentralized innovation support framework reach companies with higher barriers to innovate - like SMEs - better with their regional programmes.}

Due to a stronger regional level, decentralized countries have an advantage in reducing companies' limitations to innovate. In a centralist system, regional programmes are less likely to have the same importance and, in some countries, they are even less likely to exist. Additionally, they more closely link to national preferences, which define the general policy outline in a centralized system.

In a decentralized framework, different aspects are likely to positively influence the likelihood of support for companies with higher barriers to innovate, including the linkage to regional preferences, as well as more regional programmes and a greater power to develop new 
programmes regionally. Fernández-Ribas (2009) and Becker (2013) find a positive effect in two decentralized countries, namely Spain and Germany, respectively. A decentralized system is thus also likely to positively influence the reception of public support in other countries. These expectations are tested in hypothesis 2, and we expect positive coefficients for SMEs in federal and semi-federal countries, especially regarding regional support. The coefficients in centralized countries are expected to be smaller or even negative for SMEs.

\section{Hypothesis 3: National and supranational programmes have a stronger influence in terms of fostering innovative activities in SMEs in centralist countries.}

Although decentralized systems are expected to support firms with barriers to innovate with their regional programmes, centralized countries also focus on such firms. As regional programmes are less important in centralist countries, existing innovation support - especially at the national and supranational level - has to focus more strongly on these companies compared to decentralized countries. We expect positive effects of national and supranational programmes on SMEs in centralist countries, which forms the test for hypothesis 3 . Therefore, we expect positive coefficients for SMEs in centralized countries at the national and European level.

\section{Hypothesis 4: All programmes focus on companies with a non-regional market focus.}

Cantner and Kösters (2012) and Radicic and Pugh (2013) emphasize the problem of 'cream skimming': creators of innovation support programmes select those innovation projects that succeed anyway in order to show off their work. As a proxy for their findings, we see the market focus of the firms supported, namely those with a national and international market focus can be seen as better flagships to show successes. If this is the case, support programmes would focus on companies that not only have a regional market focus, but at least a national if not an international market focus. This 'cream-skimming' and seeking successful flagship projects is analysed with hypothesis 4 . Accordingly, we expect a strong and positive influence of a national or an international market focus on the likelihood of receiving innovation support.

\section{Hypothesis 5: All programmes focus on companies that regularly spend a higher amount of money on innovative activities.}

Firms that regularly spend more money on innovative activities such as $R \& D$ are generally more likely to receive public innovation support. A higher basis of innovative activities filters for the firms that managed to overcome their barriers to innovate, although it can also be seen as another proxy for cream-skimming. Becker (2013) finds an influence in Germany, whereas Busom and 
Fernández-Ribas (2007) find no such influence for Spain, testing for the regularity of R\&D. We expect a positive coefficient for money spent on innovative activities, as well as their regularity.

\section{Hypothesis 6: Companies that receive innovation support generally have a higher likelihood of introducing innovations in either their products, services and processes or marketing and organization.}

Innovation support is supposed to foster innovations despite mixed results in the literature. There, Hussinger (2008, p. 743) finds a positive influence on sales, while Maliranta (2000, p. 117) finds unclear effects of public innovation support on job creation. We expect positive yet minor treatment effects.

\section{Data and methods}

\subsection{Data}

We use data from the CIS, which Eurostat coordinates. Eurostat harmonizes data from the Member States of the EU from the Oslo manual (OECD, 1997). Given that the CIS is an unbalanced panel, companies might not be included in two consecutive waves. Indeed, this criticism is raised by Mairesse and Mohnen (2010, p. 1149), who argue for a longitudinal data set. However, as we do not have such a data set, we decide to use only one data wave from 2008 . In 2008, 22 countries $^{6}$ form part of the non-anonymized data wave, ${ }^{7}$ which includes more detailed data on R\&D expenditure for some of the countries compared with earlier and later data waves. Although the CIS data are harmonized, huge differences in data quality exist (see, for example, Thomä and Bizer, 2013, p. 41) and more harmonization would be useful (see Mairesse and Mohnen, 2010, p. 1147). Due to this problem, we have to reduce the sample to sixteen countries: Germany as the only federal country, Finland, the Netherlands and Spain as semi-federal countries, as well as Bulgaria, Czech Republic, Estonia, France, Hungary, Latvia, Lithuania, Luxembourg, Portugal, Romania, Slovak Republic and Slovenia as centralist countries. Dropped countries show either measurement differences or missing values in core variables. As an example, Sweden does not report which firms received public support in 2008.

\footnotetext{
${ }^{6}$ Bulgaria, Cyprus, Czech Republic, Germany, Estonia, Spain, Finland, France, Hungary, Ireland, Italy, Lithuania, Luxembourg, Latvia, Malta, Netherlands, Portugal, Romania, Sweden, Slovenia, Slovak Republic and Norway.

7 The non-anonymized data includes exact values for R\&D expenditure, numbers of employees and other characteristics that we use in this study.
} 
In some countries like Spain, participation in the CIS is mandatory. This leads to an overrepresentation of Spanish companies, combined with poorer data quality on average.

The selected countries comprise 77,779 observations in 2008 . The countries represent approximately 290 million inhabitants of the EU, 48 per cent of whom represent the centralist countries, meaning that semi-federal and federal countries together represent slightly more than half of our sample in terms of population size.

Before analysing the non-anonymized data from 2008, we found similar effects with the anonymized CIS data from 2004 and 2008. 
Table 3: Country information

\begin{tabular}{llll}
\hline Country & Observations & Per cent & Cumulative \\
\hline Bulgaria & 3,817 & 4.91 & 4.91 \\
Czech Republic & 2,828 & 3.64 & 8.54 \\
Estonia & 1,119 & 1.44 & 9.98 \\
Finland & 1,395 & 1.79 & 11.78 \\
France & 7,409 & 9.53 & 21.30 \\
Germany & 5,356 & 6.89 & 28.19 \\
Hungary & 1,453 & 1.87 & 30.06 \\
Latvia & 339 & 0.44 & 30.49 \\
Lithuania & 2,111 & 2.71 & 33.21 \\
Luxembourg & 323 & 0.42 & 33.62 \\
The Netherlands & 3,724 & 4.79 & 38.41 \\
Portugal & 3,770 & 4.85 & 43.26 \\
Romania & 2,489 & 3.20 & 46.46 \\
Slovak Republic & 651 & 0.84 & 47.29 \\
Slovenia & 1,000 & 1.29 & 48.58 \\
Spain & 39,995 & 51.42 & 100.00 \\
\hline & \multicolumn{3}{l}{} \\
Total & 77,779 & $100.00 \%$ & \\
\hline
\end{tabular}

Data: Eurostat CIS 2008 microdata; Notes: Calculated with Stata (2014). 


\subsection{Binary regressions}

We use binary variables of the reception of public innovation support from a certain political level as dependent variables in our structural models. The models test for influential factors of receiving support and calculate the propensity scores. As combinations of support from different levels are possible, we choose seven mutually exclusive binary variables, whereby funloconly (regional level), fungmtonly (national level) and funeuonly (European level) equal one if the firm only received money from the respective political level. The variables funlocgmt (regional and national level), funloceu (regional and European level) and fungmteu (national and European level) equal one for the respective combinations, which is also the case for funall if all three political levels grant public innovation support. Like Blanes and Busom (2004, p. 1467), we only observe the reception of a subsidy and not the application procedure.

We want to test for the influence of firm characteristics - especially firm size and the political system in which the firm is located - on the likelihood of receiving public support. Our main set of explanatory variables focuses on three interacted dummy variables, which combine firm size with the political system: when a firm is small and medium-sized according to the EU definition ${ }^{8}$ and in a centralist country, censme equals one. We create comparable dummy variables in a semifederal country with semsme and fedsme in a federal country. Large companies serve independent of the political system as the reference category.

We use foreign if a company has its headquarters in another country and regular if a country regularly has in-house innovative activities as other explanatory variables. Due to data restrictions in Finland and Spain, the market focus (national and internationa) and the amount of money spent on $R \& D$ in logs (Inrdexp) can only be included in country regressions. We base our general set of variables on existing studies (Busom and Fernández-Ribas, 2007; Fernández-Ribas, 2009; Becker, 2012; Becker, 2013) to enhance comparability.

Our dependent variables have a binary outcome, which leads us to binary regression models described for instance in Wooldridge (2010, pp. 561-642) or Backhaus et al. (2000, pp. 243-296). Freedman and Berk (2008, p. 400) describe problems of combining logit regressions and propensity score matching. Furthermore, the high number of observations favours probit estimations. For these reasons, we decided to use probit regressions, which do not encounter such bias. Probits estimate coefficients that are not directly interpretable in contrast to standard ordinary least squares (OLS) regressions: directions and significances are interpretable, although the size of the coefficient is not interpretable as the size of the effect. We calculate and show the

\footnotetext{
${ }^{8}$ We implement the definition with fewer than 250 employees and turnover less than $€ 50$ million in the CIS data.
} 
marginal effects for each of our regressions in the result to make it possible to interpret the results at first glance.

Our structural models first include seven probit regressions for the seven funding variables for a joint European analysis with the variables available in all sixteen countries:

\section{Equation I: European-level analysis}

$$
\text { fun }_{i}=\beta_{0}+\beta_{1} \text { fedsme }_{i}+\beta_{2} \text { semsme }_{i}+\beta_{3} \text { censme }_{i}+\beta_{4} \text { regular }_{i}+\beta_{5} \text { foreign }_{i}+\varepsilon_{i}
$$

In a second step, we run this set of regressions for each of the sixteen countries with all available variables in the respective country:

\section{Equation II: Country-level analysis}

$$
\begin{gathered}
\text { fun }_{i}=\beta_{0}+\beta_{1} \text { fedsme }_{i}+\beta_{2} \text { semsme }_{i}+\beta_{3} \text { censme }_{i}+\beta_{4} \text { national }_{i}+\beta_{5} \text { international }_{i} \\
+\beta_{6} \text { lnrdexp }_{i}+\beta_{7} \text { regular }_{i}+\beta_{8} \text { foreign }_{i}+\varepsilon_{i}
\end{gathered}
$$

The market focus cannot be analysed in Finland and Spain and the R\&D expenditure cannot be analysed in Finland. Moreover, some of the regressions are not econometrically valid in smaller countries due to a lack of observations. 
Table 4: Summary characteristics of variables

\begin{tabular}{|c|c|c|c|c|}
\hline Variable & Observations & Mean & Std. Dev. & $\begin{array}{l}Y=1 \\
\text { (\% for Bin. } \\
\text { Var.) }\end{array}$ \\
\hline $\begin{array}{l}\text { funloconly } \\
\text { (regional funding only) }\end{array}$ & 77,779 & 0.044 & 0.205 & 4.40 \\
\hline $\begin{array}{l}\text { fungmtonly } \\
\text { (national funding only) }\end{array}$ & 77,779 & 0.062 & 0.242 & 6.25 \\
\hline $\begin{array}{l}\text { funeuonly } \\
\text { (EU funding only) }\end{array}$ & 77,779 & 0.014 & 0.119 & 1.45 \\
\hline $\begin{array}{l}\text { funlocgmt } \\
\text { (regional and national funding) }\end{array}$ & 77,779 & 0.023 & 0.148 & 2.25 \\
\hline $\begin{array}{l}\text { funloceu } \\
\text { (regional and EU funding) }\end{array}$ & 77,779 & 0.003 & 0.053 & 0.28 \\
\hline $\begin{array}{l}\text { fungmteu } \\
\text { (national and EU funding) } \\
\text { funall }\end{array}$ & 77,779 & 0.012 & 0.110 & 1.21 \\
\hline $\begin{array}{l}\text { (regional, national and EU } \\
\text { funding) }\end{array}$ & 77,779 & 0.010 & 0.101 & 1.02 \\
\hline $\begin{array}{l}\text { fedsme } \\
\text { (SME from a federal country) }\end{array}$ & 77,779 & 0.038 & 0.191 & 3.80 \\
\hline $\begin{array}{l}\text { censme } \\
\text { (SME from a centralist country) } \\
\text { semsme }\end{array}$ & 77,779 & 0.179 & 0.383 & 17.87 \\
\hline $\begin{array}{l}\text { (SME from a semi-federal } \\
\text { country) }\end{array}$ & 77,779 & 0.379 & 0.485 & 37.86 \\
\hline $\begin{array}{l}\text { national } \\
\text { (national market focus) }\end{array}$ & 35,751 & 0.484 & 0.500 & 48.38 \\
\hline $\begin{array}{l}\text { international } \\
\text { (international market focus) }\end{array}$ & 35,751 & 0.221 & 0.415 & 22.15 \\
\hline $\begin{array}{l}\text { Inrdexp } \\
\text { (R\&D expenditures in logs) }\end{array}$ & 37,894 & 11.802 & 2.149 & \\
\hline $\begin{array}{l}\text { foreign } \\
\text { (foreign owned company) }\end{array}$ & 77,779 & 0.119 & 0.323 & 11.87 \\
\hline $\begin{array}{l}\text { regular } \\
\text { (regular } R \& D \text { activities) }\end{array}$ & 77,779 & 0.209 & 0.407 & 20.93 \\
\hline
\end{tabular}

Data: Eurostat CIS 2008 microdata; Notes: Calculated with Stata (2014).

\subsection{Propensity score matching}

Similar to Fernández-Ribas (2009), we use a propensity score matching to test for the effects of public support, as we cannot simultaneously compare the effect of a granted subsidy and no subsidy in one company. This leads us to the problems of non-randomness and selection. Among others, Almus and Czarnitzki (2003, p. 230), Görg and Strobl (2007, p. 216), González Cerdeira and Pazó Martínez (2008, p. 377) and Lee (2011, p. 257) mention this problem. In addition to nonrandomness, problems can also emerge with omitted or unobservable variables (see Freedman and Berk, 2008, p. 394; Bernini and Pellegrini, 2011, p. 255), which have to be taken into account. 
Different solutions to tackle the problems are described in Hussinger (2008, p. 730), while a general introduction can be found in Wooldridge (2010, pp. 903-981).

As we use the CIS 2008, we decide to use a propensity matching approach implemented in Stata (2014) by Leuven and Sianesi (2003): ${ }^{9}$ Therefore, we estimate a propensity score by nearest neighbour matching and calculate the effect of public innovation support on four dummy variables: pdinno, which equals one if the firm introduced a new product or service; prinno, which equals one if the firm introduced a new process; orinno, which equals one for a new organizational structure in the company; and mrinno, which equals one if a new marketing measure was established. Additionally, we include two variables, newmar and newfirm, which indicate the turnover generated by products (or services) newly introduced to either the entire market (newmar) or the firm (newfirm).

These variables form our set of indicators Inno upon which we assume that the innovation support has an influence. Together with the propensity to receive innovation support Funi, we can calculate the average treatment effect on the treated (ATT). Our matching ensures that firms with similar characteristics are compared as supported and non-supported companies.

Due to the seven different dependent variables in our probit regressions, we also estimate seven different propensity scores for the different sets of public innovation support, plus separate propensity scores in the country regressions.

\footnotetext{
${ }^{9}$ For the advantages of propensity score matching with CIS data, see Czarnitzki et al. (2007, p. 1354).
} 
Table 5: Characteristics of Supported Firms in Europe by Level of Support (Marginal Effects of probit regressions)

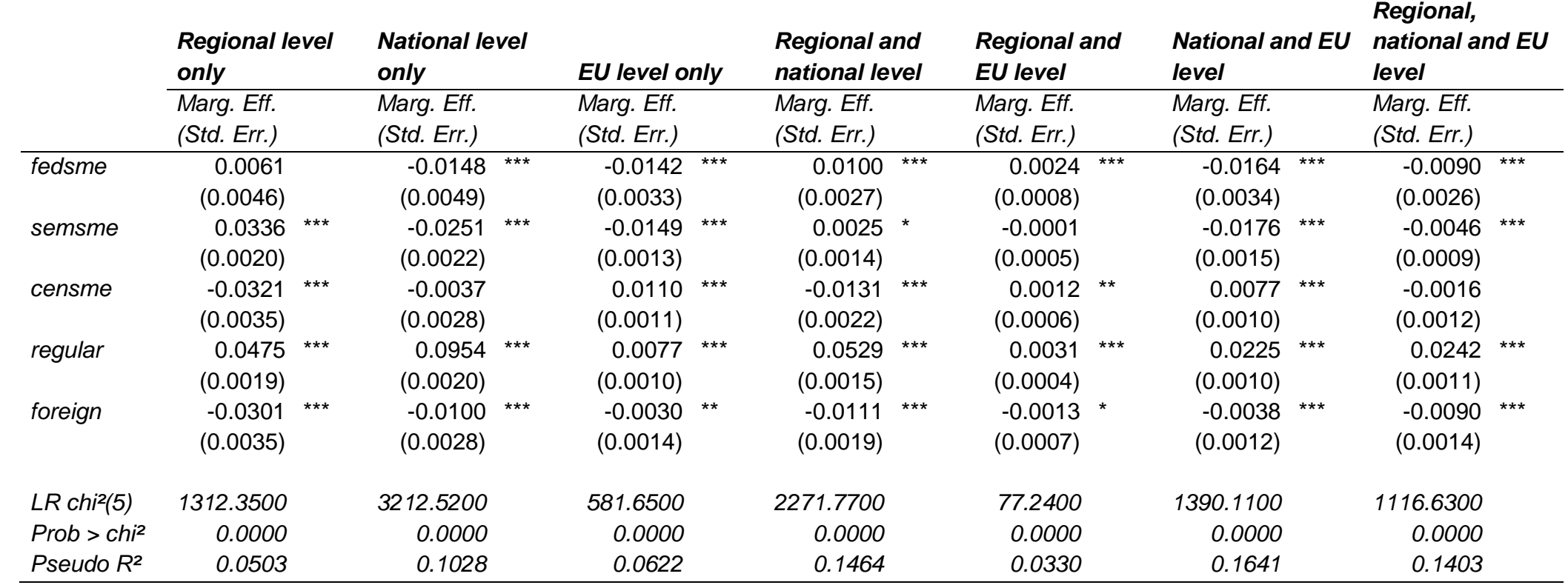

Data: Eurostat CIS 2008 microdata; Notes: Calculated with Stata (2014); ${ }^{* *}$ denotes significance at $1 \%$ level; ${ }^{* *}$ at $5 \%$ level; ${ }^{*}$ at $10 \%$ level. 
Table 6: Average Treatment Effects of the Treated (ATT, difference between treated and controls)

Regional,

\begin{tabular}{|c|c|c|c|c|c|c|c|}
\hline & $\begin{array}{l}\text { Regional level } \\
\text { only }\end{array}$ & $\begin{array}{l}\text { National level } \\
\text { only }\end{array}$ & EU level only & $\begin{array}{l}\text { Regional and } \\
\text { national level }\end{array}$ & $\begin{array}{l}\text { Regional and } \\
\text { EU level }\end{array}$ & $\begin{array}{l}\text { National and EU } \\
\text { level }\end{array}$ & $\begin{array}{l}\text { national and EU } \\
\text { level }\end{array}$ \\
\hline & $A T T$ & $A T T$ & ATT & ATT & $A T T$ & $A T T$ & $A T T$ \\
\hline & (Std. Err.) & (Std. Err.) & (Std. Err.) & (Std. Err.) & (Std. Err.) & (Std. Err.) & (Std. Err.) \\
\hline \multirow[t]{2}{*}{ pdinno } & -0.1408 & 0.1891 & 0.1931 & 0.1412 & 0.1377 & 0.1458 & 0.1114 \\
\hline & $(0.2658)$ & $(0.2039)$ & $(0.2189)$ & $(0.2322)$ & $(0.1957)$ & $(0.2430)$ & $(0.2489)$ \\
\hline \multirow[t]{2}{*}{ psinno } & 0.4772 & -0.0356 & 0.3051 & -0.1448 & 0.1257 & 0.0735 & 0.1518 \\
\hline & $(0.2605)$ & $(0.1998)$ & $(0.2145)$ & $(0.2276)$ & $(0.1915)$ & (0.2307) & $(0.2491)$ \\
\hline \multirow[t]{2}{*}{ orinno } & 0.3521 & 0.2786 & 0.4149 & 0.2467 & 0.2814 & 0.4774 & 0.2159 \\
\hline & $(0.2605)$ & $(0.1869)$ & $(0.2009)$ & $(0.2129)$ & $(0.1802)$ & $(0.2308)$ & $(0.2284)$ \\
\hline \multirow[t]{2}{*}{ mrinno } & -0.1187 & 0.1188 & 0.1931 & 0.0739 & 0.1018 & 0.4348 & -0.0460 \\
\hline & $(0.2437)$ & $(0.1998)$ & $(0.2147)$ & $(0.2276)$ & $(0.1925)$ & $(0.2309)$ & $(0.2493)$ \\
\hline \multirow[t]{2}{*}{ newmar } & 0.0797 & 0.0652 & 0.0994 & 0.0653 & 0.0575 & 0.1295 & -0.0681 \\
\hline & (0.0807) & (0.0373) & $(0.0406)$ & $(0.0428)$ & $(0.0396)$ & $(0.0472)$ & (0.0887) \\
\hline \multirow[t]{2}{*}{ newfirm } & 0.1082 & 0.1169 & 0.1351 & 0.1429 & 0.1068 & 0.1289 & 0.0328 \\
\hline & $(0.0490)$ & $(0.0163)$ & $(0.0191)$ & $(0.0190)$ & $(0.0232)$ & $(0.0171)$ & $(0.0496)$ \\
\hline
\end{tabular}

Data: Eurostat CIS 2008 microdata; Notes: Calculated with Stata (2014) and Leuven and Sianesi (2003), Std. Err. does not take into account that the propensity score is estimated; ${ }^{* \star \star}$ denotes significance at $1 \%$ level; ${ }^{* \star}$ at $5 \%$ level; ${ }^{*}$ at $10 \%$ level. 
Table 7: Directions of SME coefficients in European countries by level of support (in probit estimations)

Regional,

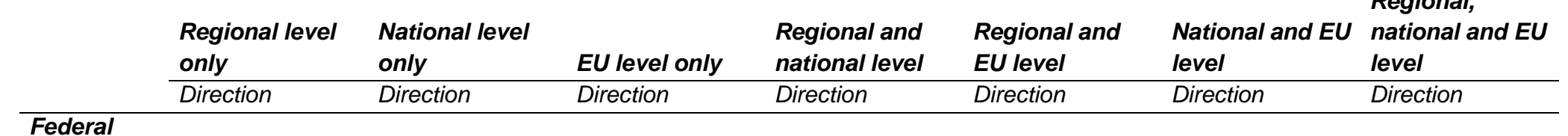

Federal
Germany

\section{Semi-}

Federal

Finland

The

Netherlands

Spain

Centralist

Bulgaria

Czech

Republic

Estonia

France

Hungary

Lithuania

Luxembourg

Latvia

Portugal

Romania

Slovenia

Slovak

Republic

Data: Eurostat CIS 2008 microdata; Notes: Calculated with Stata (2014); . stands for missing coefficients or regressions, + for a positive coefficient, - for a negative

coefficient; ${ }^{* * \star}$ denotes significance at $1 \%$ level; ${ }^{* *}$ at $5 \%$ level; ${ }^{*}$ at $10 \%$ level; direction of significant coefficients printed in bold. 


\section{$5 \quad$ Results}

The structural equations aggregated at the European level as well as the different country equations clarify the influences of the political systems: while regional programmes always show a positive influence in federal and semi-federal countries, the effect for centralist countries is negative at the European level and very mixed in the different centralist countries.

The marginal effects of the seven probits for the European comparison are described in Table 5. We focus our analysis on the SME dummies; therefore, we show the direction of the coefficients (either positive or negative) from the different countries in Table 7.

In the European comparison, most of the coefficients are significant. In the country regressions, the relatively small samples in some countries - especially the smaller ones like Latvia, the Slovak Republic or Slovenia - lead to econometrical problems and less significant results.

In the EU comparison, we find positive coefficients for the federal and semi-federal SME dummies with regional level support programmes (albeit only with the last group being statistically significant). This is the case if a firm only receives regional support or a combination of regional and national or regional and European support (with the last combination not significant and minimally below zero for semi-federal SMEs). By contrast, the two federal and semi-federal SME dummies turn negative for national and European support, as well as the combination of both. Moreover, the coefficient for companies receiving support from all three political levels is also negative for federal and semi-federal SMEs.

By contrast, for SMEs from centralist countries, we find a negative coefficient at the regional and national levels (with the last coefficient being slightly above zero and not significant), as well as for the combination of local and national level support. The coefficient in the estimation for solely European support turns positive, as it is also the case for the combinations of regional and European as well as national and European support. The centralist SME dummy is negative in the probit for firms receiving support from all levels, although - in contrast to the other two SME dummies in this regression - it is not significant.

In order to check for country-specific effects, we compare the country regressions. Although the econometrical problems mentioned above reduce the explanatory power, we see that regional level programmes in all federal and semi-federal countries have a positive coefficient, which is significant in all countries aside from the Netherlands.

In the centralist countries, the direction of the SME dummies for regional support varies much more strongly between countries (including in the size of their coefficients). For the other levels, 
the distinction between the political systems is less clear. We find more positive coefficients for national and European level programmes in centralist countries, although rarely significant. Moreover, a country effect for Germany - the only federal country - cannot be excluded in our variable fedsme. Unfortunately, no other federal country is available in the CIS 2008 as a comparison. However, in earlier regressions that included Belgium as another federal country, the results were similar. ${ }^{10}$

Regarding the marginal effects, we find a variety of effects from almost 0 for the combination of local and European support to up to 0.03 for semi-federal SMEs at the regional level (positive coefficient) and centralist SMEs with the combination of regional and national support (negative coefficient). Generally, we see that negative effects are greater than positive effects (except for regional support and semi-federal SMEs). As indicated by higher values of the marginal effects, the economic relevance is much greater for our dummy variable concerning whether a firm regularly spent money on innovative activities in the European comparison. Only for European level support and the combination of local and European level support is the coefficient smaller than some of the SME dummies. It always reaches a higher level of econometrical significance. In the country regressions, we analyse the influence of the money spent on R\&D in a company. Aside from regional support only, the coefficient is positive and often significant in almost all countries. This underlines the effect measured in the EU comparison by the dummy for regular spending.

All levels of political support focus on domestic companies. Negative - and for some levels high marginal effects show this for our dummy variable for foreign companies. We find a smaller and less significant coefficient for European support only and its combinations, although the direction remains negative.

In our country regressions, ${ }^{11}$ we analyse the influence of national or international market focus, as well as internal R\&D expenditure (in logs). The results can be seen in Tables 8, 9 and 10.

We do not find a clear direction of the effect for the market focus of the analysed firms: the coefficients are rarely significant and the direction of their effect often varies. While the only significant coefficients are negative for regional level programmes, there is a positive coefficient (with the exception of Estonia) for national level programmes and an unclear effect for EU level

\footnotetext{
${ }^{10}$ In a preliminary version, we compared Belgium with data from 2004 . We found similar results, although the 2004 data wave included fewer variables and various other countries were missing. Therefore, we decided to focus on the 2008 data wave.

11 The respective variables are not available in all countries; therefore, the variables are excluded for the European analysis.
} 
programmes and the combination of two different levels. The effect in companies that receive support from all three levels is generally negative, with the exception of France). Here, we have to assume stronger country effects but we can see an influence of regional programmes, which more strongly focus on companies with a regional market focus. In contrast to earlier findings in Germany by Becker (2013, p. 13), the coefficients are not significant in federal and semi-federal countries. This effect does not seem to be influenced by political systems.

In contrast to these mixed findings, we find a strong and positive influence of the expenditure spent on R\&D within a company at all political levels; indeed, this result is similar in all countries across Europe. Out of all the significant coefficients from different countries, only the coefficient for Estonia is negative, while all the other coefficients are positive and often statistically highly significant. We see positive coefficients in federal, semi-federal and centralist countries. The influence of $R \& D$ investment on the likelihood of receiving public support is influential without visible differences according to the political systems.

If publicly supported, the effects on innovations are - similar to Becker (2013) for Germany and in contrast to Fernández-Ribas (2009) for Catalonia - questionable, given that none of the ATTs reported in Table 6 are significant. However, the effects are non-trivial and systematic as they remain positive, aside from product and marketing innovations in regional programmes, process innovations in national programmes, process innovations in the combination of local and national programmes and marketing innovations in our estimation for support from all three levels. This can be seen as a link to a positive (albeit not significant) influence on the innovation outcomes of the respective programmes.

Generally, the chosen firm characteristics only partly explain the reception of public innovation support. However, aside from the European level (and its combinations) estimations, our Pseudo $\mathrm{R}^{2}$ value is always above 0.05 , prompting the conclusion that our effects found are politically relevant. These effects show a clear difference between SMEs in federal and semi-federal countries on the one hand and centralist countries on the other. A generally strong influence of the regularity (and amount) of money spent on innovative activities and a lesser effect of the origin (and market focus) of the firms is supported for all political levels. 
Table 8: Directions of R\&D expenditure coefficients in European countries by level of support (in probit estimations)

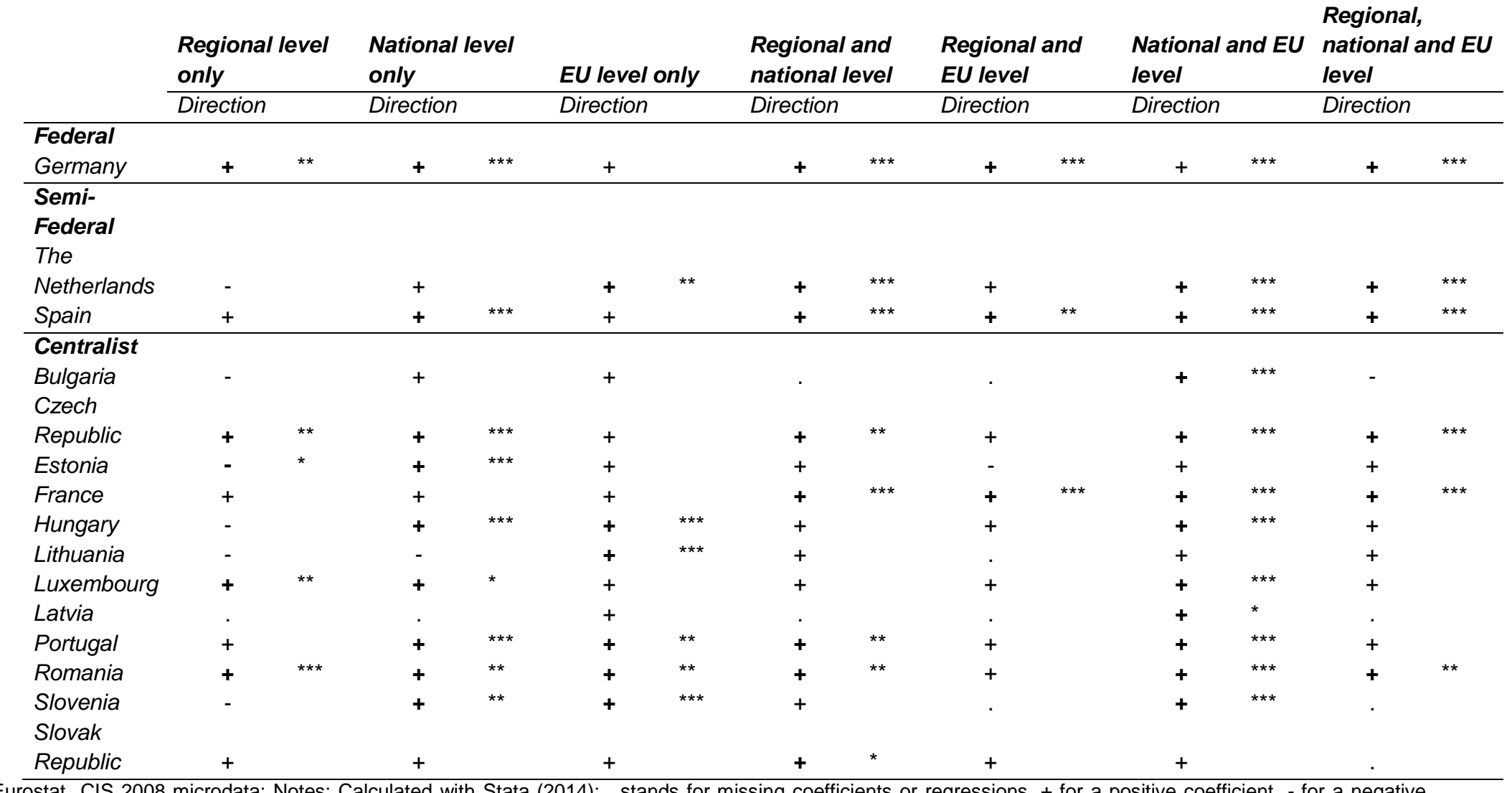

Data: Eurostat CIS 2008 microdata; Notes: Calculated with Stata (2014); . stands for missing coefficients or regressions, + for a positive coefficient, - for a negative coefficient; ${ }^{* * *}$ denotes significance at $1 \%$ level; ${ }^{* *}$ at $5 \%$ level; ${ }^{*}$ at $10 \%$ level; direction of significant coefficients printed in bold. 
Table 9: Directions of national market focus coefficients in European countries by level of support (in probit estimations)

Regional,

\begin{tabular}{|c|c|c|c|c|c|c|}
\hline $\begin{array}{l}\text { Regional level } \\
\text { only }\end{array}$ & $\begin{array}{l}\text { National level } \\
\text { only }\end{array}$ & EU level only & $\begin{array}{l}\text { Regional and } \\
\text { national level }\end{array}$ & $\begin{array}{l}\text { Regional and } \\
\text { EU level }\end{array}$ & $\begin{array}{l}\text { National and EU } \\
\text { level }\end{array}$ & $\begin{array}{l}\text { Regional, } \\
\text { national and EU } \\
\text { level }\end{array}$ \\
\hline Direction & Direction & Direction & Direction & Direction & Direction & Direction \\
\hline
\end{tabular}

\begin{tabular}{|c|c|c|c|c|c|c|c|c|}
\hline & Direction & Direction & & Direction & Direction & Direction & Direction & Direction \\
\hline Federal & & & & & & & & \\
\hline Germany & + & + & $\star \star *$ & + & - & + & + & + \\
\hline
\end{tabular}

\section{Federal}

The

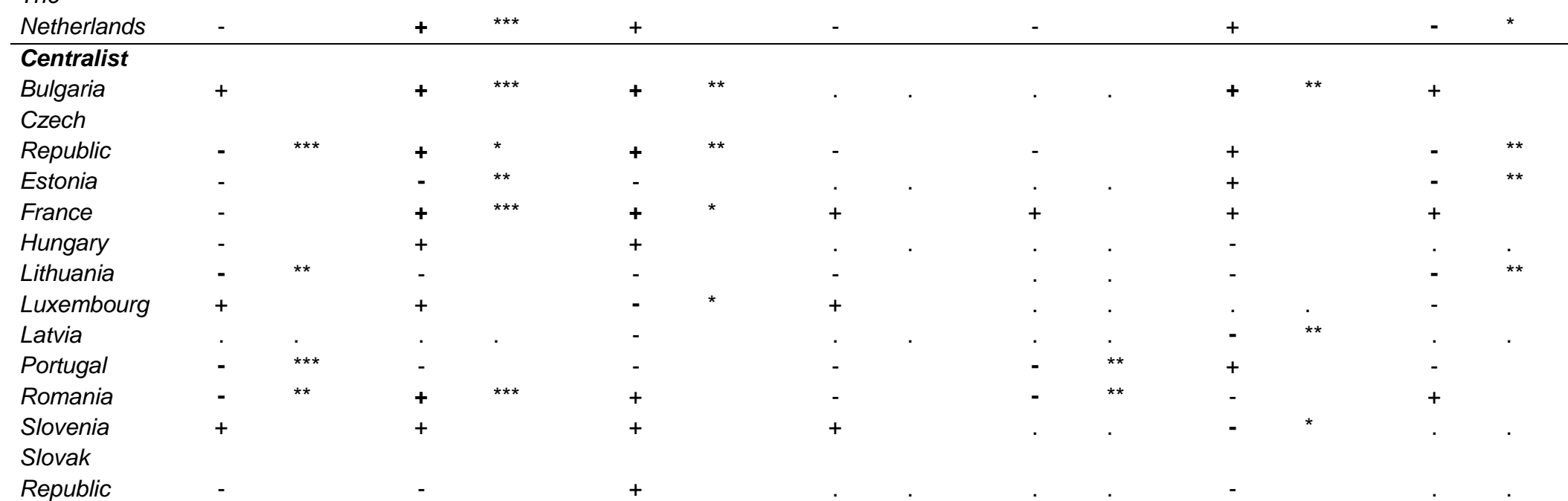

Data: Eurostat CIS 2008 microdata; Notes: Calculated with Stata (2014); . stands for missing coefficients or regressions, + for a positive coefficient, - for a negative coefficient; ${ }^{* * *}$ denotes significance at $1 \%$ level; ${ }^{* *}$ at $5 \%$ level; ${ }^{*}$ at $10 \%$ level; direction of significant coefficients printed in bold. 
Table 10: Directions of international market focus coefficients in European countries by level of support (in probit estimations)

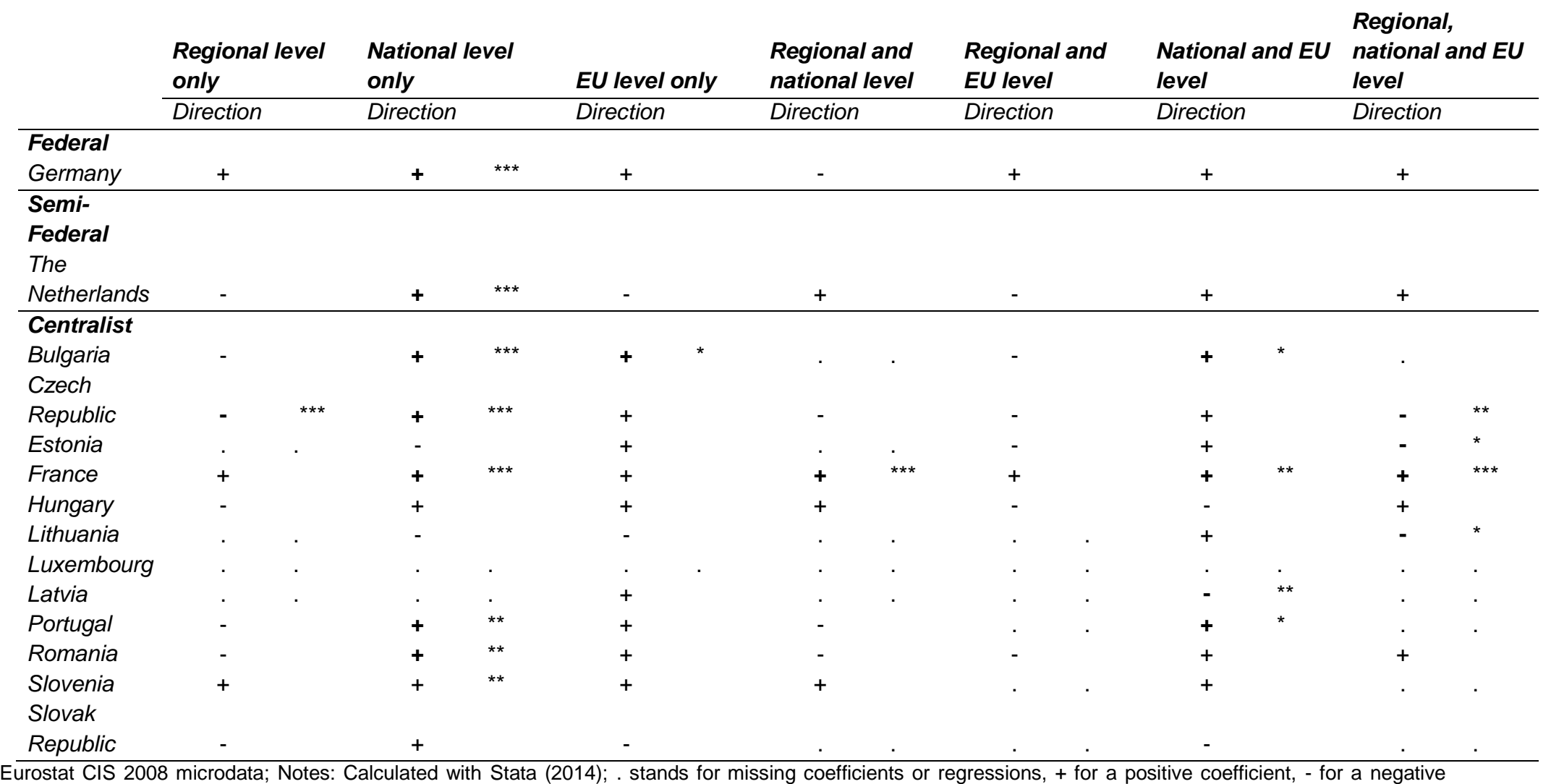

Data: Eurostat CIS 2008 microdata; Notes: Calculated with Stata (2014); . stands for missing coefficients or regressions, +
coefficient; ${ }^{* * \star}$ denotes significance at $1 \%$ level; ${ }^{* *}$ at $5 \%$ level; ${ }^{*}$ at $10 \%$ level; direction of significant coefficients printed in bold. 


\section{Discussion and conclusion}

Few studies have empirically evaluated the influence of political systems on the reception of public innovation support and no other studies have evaluated innovation support across Europe with CIS data.

Our paper analyses the firm characteristics of firms publicly supported in sixteen European countries as well as aggregated from these countries at the European level. The paper focuses on the influence of political systems and regional level support, especially for SMEs as firms with higher barriers to innovate. It analyses the different characteristics from regional, national and European level programmes, as well as common characteristics like the expenditure spent on innovative activities.

We find visible differences between federal, semi-federal and centralist countries, especially regarding the support of small and medium-sized enterprises: Regional programmes reach SMEs better, especially in federal and semi-federal countries. These findings support the theoretical point that decentralized systems more strongly focus on the regional preferences of firms with barriers to innovate, which are reflected by the smaller companies. Therefore, our hypotheses 1 and 2 are supported by our empirical findings: SMEs have greater difficulties in gaining national and supranational support and a decentralized innovation framework better reaches firms with barriers to innovate, in this case SMEs.

We find partial support for hypothesis 3. Positive influences are found for European support (and its combinations with regional or national support), in terms of national support, we do not find clear differences in the (negative) coefficients between federal, semi-federal and centralist countries. Therefore, this hypothesis has to be partially rejected, but the argument for a decentralized framework is supported.

Another partial rejection has to be drawn for hypothesis 4, which predicted that regional programmes more strongly focus on companies with a regional market focus in most countries. However, we find a positive influence of national and international market focus at the other levels of support. Nonetheless, the coefficients vary in their directions between the different countries and political systems, meaning that no general conclusion can be drawn.

As expected, regularly higher expenditures on innovative activities explain the reception of public innovation support, thus supporting hypothesis 5. Combined with the findings on SMEs, we assume that this creates an even higher barrier for the first step to innovation, whereby companies that are already innovative are more likely to receive public support, thus making it more likely that they will innovate in the future. 
Regarding hypothesis 6 , we have to reject this hypothesis as none of our average treatment effects prove significant (although 27 of 32 ATTs are positive). Therefore, generally across Europe, we do not find a significant impact of public innovation support on the likelihood of introducing product, process, organizational or marketing innovations, in any combinations of support from the different levels.

As a policy implication, a more decentralized system of public innovation support and stronger regional programmes increases the variety of firms supported. Therefore, policy-makers should learn from positive examples of regional innovation support across Europe. However, this fact does not say anything about the effectiveness of public innovation support, which provides ample scope for future research.

While country effects vary between the European countries, our results suggest some common tendencies in the sixteen European countries chosen and particularly across similar political systems, meaning that political actors can learn from other countries in Europe.

This leads us to a further necessity for policy evaluation concerning public support programmes: while many programmes claim to reach SMEs (and other firms that face barriers to innovate), only regional programmes seem to reach them. Combined with issues concerning the effectiveness of support, this has to be further analysed for both individual countries and the EU as a whole. 


\section{Acknowledgements}

This paper is based on data from Eurostat Community Innovation Survey. The responsibility for all conclusions drawn from the data lies entirely with the authors.

Thanks to Prof. Dr. Markus Spiwoks and the PhD students for their input during two seminars at the Georg-August-University in Göttingen, as well as the participants of the Schumpeter Conference 2014 for their feedback. Special thanks to Eurostat and especially Geneviève Villette. Additionally, we are grateful to all those who checked this paper for linguistic errors.

This work was supported by the German Bundesministerium für Bildung und Forschung (BMBF) via Friedrich-Naumann-Stiftung für die Freiheit (FNF). 


\section{References}

Aerts, K., Czarnitzki, D., 2004. Using Innovation Survey Data to Evaluate R\&D Policy: The Case of Belgium. ZEW Discussion Paper No. 04-55. ZEW, Mannheim, 25 pp. (downloaded on 11 March 2015 from ftp://ftp.zew.de/pub/zew-docs/dp/dp0455.pdf).

Almus, M., Czarnitzki, D., 2003. The effects of public R\&D subsidies on firms' innovation activities: The case of Eastern Germany. Journal of business \& economic statistics : JBES ; a publication of the American Statistical Association 21 (2), 226-236.

Arrow, K.J., 1962. Economic welfare and the allocation of resources for invention, in: The rate and direction of inventive activity. economic and social factors. a conference of the Universities-National Bureau Committee for Economic Research and the Committee on Economic Growth of the Social Science Research Council, pp. 609-625.

Atkinson, R.D., 1991. Innovation policy making in a federalist system: Lessons from the states for U.S. federal innovation policy making. Research Policy 20 (6), 559-577.

Audretsch, D.B., 2001. The dynamic role of small firms : evidence from the US. World Bank Institute, Washington D.C.

Backhaus, K., Erichson, B., Plinke, W., Weiber, R., 2000. Multivariate Analysemethoden : eine anwendungsorientierte Einführung (12th ed.). Springer, cBerlin [u.a.].

Beaudry, C., Breschi, S., 2003. Are firms in clusters really more innovative? Economics of Innovation \& New Technology 12 (4), 325-342.

Becker, L., 2012. Innovation subsidies in a federal system: Innovation policy at different political levels in Germany, in: Proceedings of the 2nd annual International Conference on Innovation and Entrepreneurship (IE 2012). GSTF, Singapore, pp. 59-64.

Becker, L., 2013. No gains of federalism in innovation support?: The case of Germany, in: Conference Proceedings 35th DRUID Celebration Conference 2013. 35th DRUID Celebration Conference 2013, Barcelona. online.

Bernini, C., Pellegrini, G., 2011. How are growth and productivity in private firms affected by public subsidy?: Evidence from a regional policy. Regional science \& urban economics 41 (3), 253-265.

Blanes, J.V., Busom, I., 2004. Who participates in R\&D subsidy programs?: The case of Spanish manufacturing firms. Research Policy 33 (10), 1459-1476.

Blume, L., Voigt, S., 2011. Federalism and decentralization-a critical survey of frequently used indicators. Constitutional Political Economy 22 (3), 238-264.

Bohnstedt, A., 2014. Are public and private R\&D investments complements or substitutes? Ruhr economic papers, Essen, 18 pp. http://www.rwi-essen.de/publikationen/ruhr-economicpapers/617/).

Braun, D., 2008. Lessons on the political coordination of knowledge and innovation policies. Science and Public Policy 35 (4), 289-298.

Brouwer, M.T., 2000. Entrepreneurship and uncertainty: innovation and competition among the many. Small Business Economics 15 (2), 149-160.

Brown, C., Hamilton, J., Medoff, J.L., 1990. Employers large and small. Harvard University Press, Cambridge, Mass [u.a.].

Busom, I., 2000. An Empirical Evaluation of the Effects of R\&D Subsidies. Economics of Innovation \& New Technology 9 (2), 111-149.

Busom, I., Fernández-Ribas, A., 2007. Do R\&D Programs of Different Government Levels Overlap in the European Union?, in: Science, Technology and Innovation Policy. Atlanta Conference on Science, Technology and Innovation Policy, Atlanta. 19-20 Oct. 2007, pp. 15.

Cantner, U., Kösters, S., 2012. Picking the winner?: Empirical evidence on the targeting of R\&D subsidies to start-ups. Small Business Economics 39 (4), 921-936.

Cerulli, G., 2010. Modelling and measuring the effect of public subsidies on business R\&D: A critical review of the econometric literature. The economic record : er 86 (274), 421-449. 
Clausen, T.H., 2009. Do subsidies have positive impacts on R\&D and innovation activities at the firm level? Structural change and economic dynamics 20 (4), 239-253.

Czarnitzki, D., Ebersberger, B., Fier, A., 2007. The relationship between R\&D collaboration, subsidies and R\&D performance: Empirical evidence from Finland and Germany. Journal of Applied Econometrics 22 (7), 1347-1366.

Czarnitzki, D., Fier, A., 2002. Do Innovation Subsidies Crowd Out Private Investment? Evidence from the German Service Sector. Applied Economics Quarterly (Konjunkturpolitik) 48 (1), 125.

Czarnitzki, D., Hanel, P., Rosa, J.M., 2011. Evaluating the impact of R\&D tax credits on innovation: A microeconomic study on Canadian firms. Research Policy 40 (2), 217-229.

Czarnitzki, D., Toole, A.A., 2008. The R \& D investment uncertainty relationship: Do competition and firm size matter? Discussion paper / ZEW Zentrum für Europäische

Wirtschaftsforschung, Mannheim, 18 S (downloaded on 11 March 2015 from http://ftp.zew.de/pub/zew-docs/dp/dp08013.pdf).

David, P.A., Hall, B.H., Toole, A.A., 2000. Is public R\&D a complement or substitute for private R\&D? A review of the econometric evidence. Research Policy 29 (4-5), 407-529.

Duguet, E., 2004. Are R\&D subsidies a substitute or a complement to privately funded R\&D ? An econometric analysis at the firm level. Revue d'Economie Politique 114 (2), 245-274.

Edler, J., Kuhlmann, S., 2008. Coordination within fragmentation: governance in knowledge policy in the German federal system. Science and Public Policy 35 (4), 265-276.

European Commission, 2013. State Aid Scoreboard 2013: Non-crisis aid (downloaded on 19 June 2014 from http://ec.europa.eu/competition/state_aid/scoreboard/non_crisis_en.html).

Eurostat. Community Innovation Survey (CIS), Luxemburg.

Feld, L.P., 2007. Zur ökonomischen Theorie des Föderalismus: Eine prozeßorientierte Sicht, in: Heine, K., Kerber, W. (Eds), Zentralität und Dezentralität von Regulierung in Europa. Lucius \& Lucius, Stuttgart, pp. 31-54.

Fernández-Ribas, A., 2009. Public support to private innovation in multi-level governance systems: an empirical investigation. Science and Public Policy 36, 457-467.

Fier, A., Czarnitzki, D., 2005. Zum Stand der empirischen Wirkungsanalyse der öffentlichen Innovations- und Forschungsförderung (downloaded on 11 March 2015 from http://www.zew.de/de/publikationen/evaluationinno/ZEW_Ueberblick_Wirkungsanalyse.pdf).

Freedman, D.A., Berk, R.A., 2008. Weighting Regressions by Propensity Scores. Evaluation Review 32 (4), 392-409.

González Cerdeira, X., Pazó Martínez, C., 2008. Do public subsidies stimulate private R\&D spending? Research Policy 37 (3), 371-389.

Görg, H., Strobl, E., 2007. The Effect of R\&D Subsidies on Private R\&D. Economica 74 (294), 215-234.

Griliches, Z., 1992. The Search for R\&D Spillovers. The Scandinavian Journal of Economics 94, 29-47.

Grossman, G.M., Helpman, Elhanan, 1994. Endogenous Innovation in the Theory of Growth. The Journal of Economic Perspectives, 8 (1), 23-44.

Hall, B., Mairesse, J., Mohnen, P., 2009. Measuring the Returns to R\&D. National Bureau of Economic Research, Cambridge, MA.

Hayek, F.A. von, 1948. Individualism and economic order. Univ. of Chicago Press, London.

Hong, S., Oxley, L., McCann, P., 2012. A survey of the innovation surveys. Journal of economic surveys 26 (3), 420-444.

Hussinger, K., 2008. R\&D and subsidies at the firm level: An application of parametric and semiparametric two-step selection models. Journal of Applied Econometrics 23 (6), 729-747.

Klette, T.J., Møen, J., Griliches, Z., 2000. Do subsidies to commercial R\&D reduce market failures?: Microeconometric evaluation studies. Research Policy 29 (4/5), 471-495.

Koga, T., 2005. R\&D subsidy and self-financed R\&D: The case of Japanese high-technology start-ups. Small business economics : an internat. journal 24 (1), 53-62. 
Konings, J., Torfs, W., 2011. Fiscal Federalism, Tax Competition and Economic Agglomeration, in: Flemish Department of Finance and Budget (Ed), Fiscal Federalism in the European Union. EU Presidency Seminar. Larcier, Brussels, pp. 35-56.

Lach, S., 2002. Do R\&D Subsidies Stimulate or Displace Private R\&D? Evidence from Israel. The Journal of Industrial Economics, 50 (4), 369-390.

Lang, G., 2009. Measuring the returns of R\&D: An empirical study of the German manufacturing sector over 45 years. Research Policy 38 (9), 1438-1445.

Lee, C.-y., 2011. The differential effects of public R\&D support on firm R\&D: Theory and evidence from multi-country data. Technovation : the international journal of technological innovation, entrepreneurship and technology management 31 (5/6), 256-269.

Leuven, E., Sianesi, B., 2003. PSMATCH2: Stata module to perform full Mahalanobis and propensity score matching, common support graphing, and covariate imbalance testing.

Levine, R., 1997. Financial Development and Economic Growth: Views and Agenda. Journal of Economic Literature 35 (2), 688-726.

Levy, D.M., 1990. Estimating the impact of government R\&D. Economics Letters 32 (2), 169173.

Lijphart, A., 2012. Patterns of democracy: Government forms and performance in thirty-six countries (2nd ed.). Yale University Press, New Haven.

Loury, G.C., 1979. Market structure and innovation. The quarterly journal of economics 93 (3), 395-410.

Mairesse, J., Mohnen, P.A., 2010. Using innovation surveys for econometric analysis, in: Hall, B.H., Rosenberg, N. (Eds), Handbook of the economics of innovation. North Holland, Amsterdam [u.a.], pp. 1129-1155.

Maliranta, M., 2000. Job creation by supporting technology advances?: Evidence from Finnish plants, in: Asplund, R. (Ed), Public R \& D funding, technological competitiveness, productivity, and job creation. Taloustieto, Helsinki, pp. 87-128.

Montmartin, B., 2011. Centralized Innovation Policy in an agglomeration and growth model: A welfare analysis http://www.worldcat.org/oclc/711418912).

Musgrave, R.A., 1959. The theory of public finance: A study in public economy. McGraw-Hill, New York.

Nelson, R.R., 1959. The Simple Economics of Basic Scientific Research. The Journal of Political Economy, 67 (3), 297-306.

Oates, W.E., 1972. Fiscal federalism. Harcourt Brace Jovanovich, New York, NY.

OECD, 1997. Oslo manual : Proposed guidelines for collecting and interpreting technological innovation data. Organisation for Economic Co-operation and Development (OECD)., Paris http://www.oecd.org/dataoecd/35/61/2367580.pdf).

OECD, 2002. Frascati manual 2002 : the measurement of scientific and technological activities; proposed standard practice for surveys of research and experimental development 254.

Organisation for Economic Co-operation and Development (OECD)., Paris http://www.Imt.It/PROJEKTAI/TEKSTAI/Frascati.pdf).

OECD, 2011. Regions and innovation policy. OECD Publ., Paris.

Radicic, D., Pugh, G., 2013. The impact of innovation support programmes on SME innovation in traditional manufacturing industries: an evaluation for seven EU regions, in: Conference Proceedings DRUID Academy 2013. DRUID Academy 2013, Aalborg. online.

Roberts, A., 2006. What Kind of Democracy Is Emerging in Eastern Europe? Post-Soviet Affairs 22 (1), 37-64.

Saam, N.J., Kerber, W., 2013. Policy Innovation, Decentralised Experimentation, and Laboratory Federalism. Journal of Artificial Societies and Social Simulation 16 (1), 7.

Schumpeter, J.A., 2008. Capitalism, socialism and democracy (3rd ed.). Harper Perennial Modern Classics, New York, NY [u. a.].

Stata, 2014. Stata. StataCorp LP. 
Stein, M., Turkewitsch, L., 2010. Multilevel Governance and Federalism: Closely Linked or Incompatible Concepts. Participation - Bulletin of the International Political Science Association 34 (2), 3-5.

Thomä, J., Bizer, K., 2013. To protect or not to protect? Modes of appropriability in the small enterprise sector. Research Policy 42 (1), 35-49.

Tiebout, C.M., 1956. A pure theory of local expenditures. Journal of Political Economy 64 (5), 416-424.

Vitola, A., 2014. Innovation policy mix in a multi-level context: The case of the Baltic Sea Region countries. Science and Public Policy.

Vonortas, N.S., Stampfer, M., Zinöcker, K., 2007. Evidence never lies: introduction to a special issue on New Frontiers in Evaluation. Science and Public Policy 34 (10), 679-680.

Wallsten, S.J., 2000. The effects of government-industry R\&D programs on private R\&D: the case of the Small Business Innovation Research program. RAND Journal of Economics (RAND Journal of Economics) 31 (1), 82-100.

Wilson, D., Souitaris, V., 2002. Do Germany's federal and land governments (still) co-ordinate their innovation policies? Research Policy 31 (7), 1123-1140.

Wooldridge, J.M., 2010. Econometric analysis of cross section and panel data (2. ed). MIT Press, Cambridge, Mass. 
Kapitel 4

\title{
Effectiveness of public innovation support in Europe
}

\section{Does public support foster turnover, employment and labour productivity?}

\author{
Eingereicht bei Journal of Evolutionary Economics \\ cege Discussion Paper No. 236
}




\begin{abstract}
In the European Union (EU), twenty Member States offer public innovation support for private research and development $(R \& D)$ activities through either subsidies or a combination of tax cuts and subsidies. Existing studies show ambiguous results regarding the effectiveness of public innovation support in different countries. Accordingly, following a description of the current public innovation framework in Europe, this paper analyses data from the European Community Innovation Survey concerning the effectiveness of public support. The measures chosen relate to changes in turnover as well as the number of employees and labour productivity (measured as turnover per employee) between 2006 and 2008. The paper finds a positive influence of public innovation support on labour productivity in an innovating company, a negative influence on turnover changes and a negative yet not significant influence on the development of employment. The influences of these factors are very weak, whereas other coefficients such as the money spent on innovative activities clearly show positive effects for all three indicators.
\end{abstract}

\title{
Key Words
}

Innovation, innovation support, labor productivity, Europe, effectiveness

\section{JEL Classification}

O31, O38, H21 


\section{Introduction}

Governments often use public subsidies or tax credits to foster private innovative activities, aiming to increase the competitiveness of firms in a jurisdiction. Existing studies have already analysed the effect of public innovation support on private $R \& D /$ innovation $^{1}$ spending, usually measured as additionality; however:

'We should not forget that, in relation to society as a whole, the R\&D effort should be taken as a "means" rather than exclusively as an "end". The objective of society should be that of increasing national firms' performance (productivity, profitability, and degree of innovativeness) to improve living standards, economic growth and so on. This means that linking $R \& D$ additionality due to subsidy programmes to firm output performances is a necessary step to give a complete account of "subsidy effectiveness".' (Cerulli 2010)

Therefore, this paper analyses whether publicly induced innovative activities foster the competitiveness of the companies supported. Regarding the aims of public innovation support programmes, supported companies should become more competitive as a result of receiving support. In Asplund (2000), different authors analyse the Finnish Tekes programme ${ }^{2}$ and find mixed results, while a recent study by Becker (2013) also finds mixed results in Germany. However, these existing studies focus on single countries or on a comparison between only a few countries or a small number of companies.

Accordingly, this study enlarges the picture by adding a European perspective, with fifteen European countries included. In particular, it analyses the development of labour productivity (measured by the turnover per employee) as well as the development of employees and turnover between 2006 and 2008 as indicators of competitiveness. Additionally, it investigates the development in the number of employees and the turnover.

With these three factors, this paper expands the analysis of effectiveness of public innovation support, evaluating the supported companies regarding competitiveness in Europe.

An overview on the existing landscape of public innovation support within the EU is provided in the first part of section two, which shows that the vast majority of twenty European countries offer either subsidies or tax cuts and subsidies for private R\&D investment.

\footnotetext{
${ }^{1}$ Within the overview, R\&D includes other innovative activities, as mentioned in European Commission (2013) or Busom et al. (2012). Therefore, R\&D is always used synonymously with R\&D\&I and innovation in general in this paper.

2 Tekes is the innovation support agency in Finland (Tekniikan edistämiskeskus - Center for Advancement of Technology).
} 
A brief overview of the literature forms the basis of this study, before different measures to evaluate the effectiveness of public support in general are elaborated from existing studies.

The hypotheses, developed in the third section, show the different aspects of effectiveness of innovative activities and subsidies. Section four describes Eurostat's Community Innovation Survey (CIS); in particular, the chosen method of matching supported and not publicly supported companies is presented due to the problem of non-randomness of selection. The results and conclusions of the analysed data are presented in the fifth section, before section five concludes.

\section{Literature review}

\subsection{Public innovation support in Europe}

Most EU Member States according to the EU State Aid Scoreboard 2013 (European Commission 2013) offer public support for private innovative activities. Aside from Germany, Lithuania and Sweden, all countries offering public innovation support grant both direct subsidies and tax credits (see Table 1).

For the OECD members, Busom et al. (2012) state the following:

'Canada, the Netherlands and Japan rely mostly on tax incentives, while direct funding is still preferred in Sweden, Finland or Germany. Other countries use both instruments simultaneously: France, Denmark, Spain, the United Kingdom and the United States.'

Nonetheless, in terms of those countries using both instruments simultaneously, differences in the relation become visible (see Busom et al. 2012). 
Table 1: Forms of public support for private R\&D in the EU

\begin{tabular}{|c|c|c|}
\hline Direct subsidies & Direct subsidies and tax credits & No relevant public innovation support* \\
\hline $\begin{array}{ll}\text { - } & \text { Germany } \\
\text { - } & \text { Lithuania } \\
\text { - } & \text { Sweden }\end{array}$ & $\begin{array}{ll}\text { - } & \text { Austria } \\
\text { - } & \text { Belgium } \\
\text { - } & \text { Czech Republic } \\
\text { - } & \text { Denmark }{ }^{* *} \\
\text { - } & \text { Finland } \\
\text { - } & \text { France } \\
\text { - } & \text { Hungary } \\
\text { - } & \text { Ireland } \\
\text { - } & \text { Italy } \\
\text { - } & \text { Luxembourg } \\
\text { - } & \text { The Netherlands } \\
\text { - } & \text { Poland } \\
\text { - } & \text { Portugal } \\
\text { - } & \text { Romania } \\
\text { - } & \text { Slovak Republic } \\
\text { - } & \text { Slovenia } \\
\text { - } & \text { Spain } \\
\text { - } & \text { Inited Kinadom }\end{array}$ & $\begin{array}{ll}\text { - } & \text { Bulgaria } \\
\text { - } & \text { Cyprus } \\
\text { - } & \text { Estonia } \\
\text { - } & \text { Greece } \\
\text { - } & \text { Latvia } \\
\text { - } & \text { Malta }\end{array}$ \\
\hline
\end{tabular}

Source: Adapted from European Commission (2013) in combination with OECD (2013) and OECD (2011); Notes: * All countries spending less than $3 \%$ of their total aid budget in 2012 are appointed to this category. ${ }^{*}$ OECD (2011) claims no public innovation support for private R\&D in Denmark, while other sources show both tax incentives and public subsidies. ${ }^{* * *}$ Between 2007 and 2012 Romania reduced its spending on R\&D support nearly to zero; countries included in this study in bold. 
Figure 1: Relative share of public support of R\&D (\&I) among total public aid (average of 2007-2012)

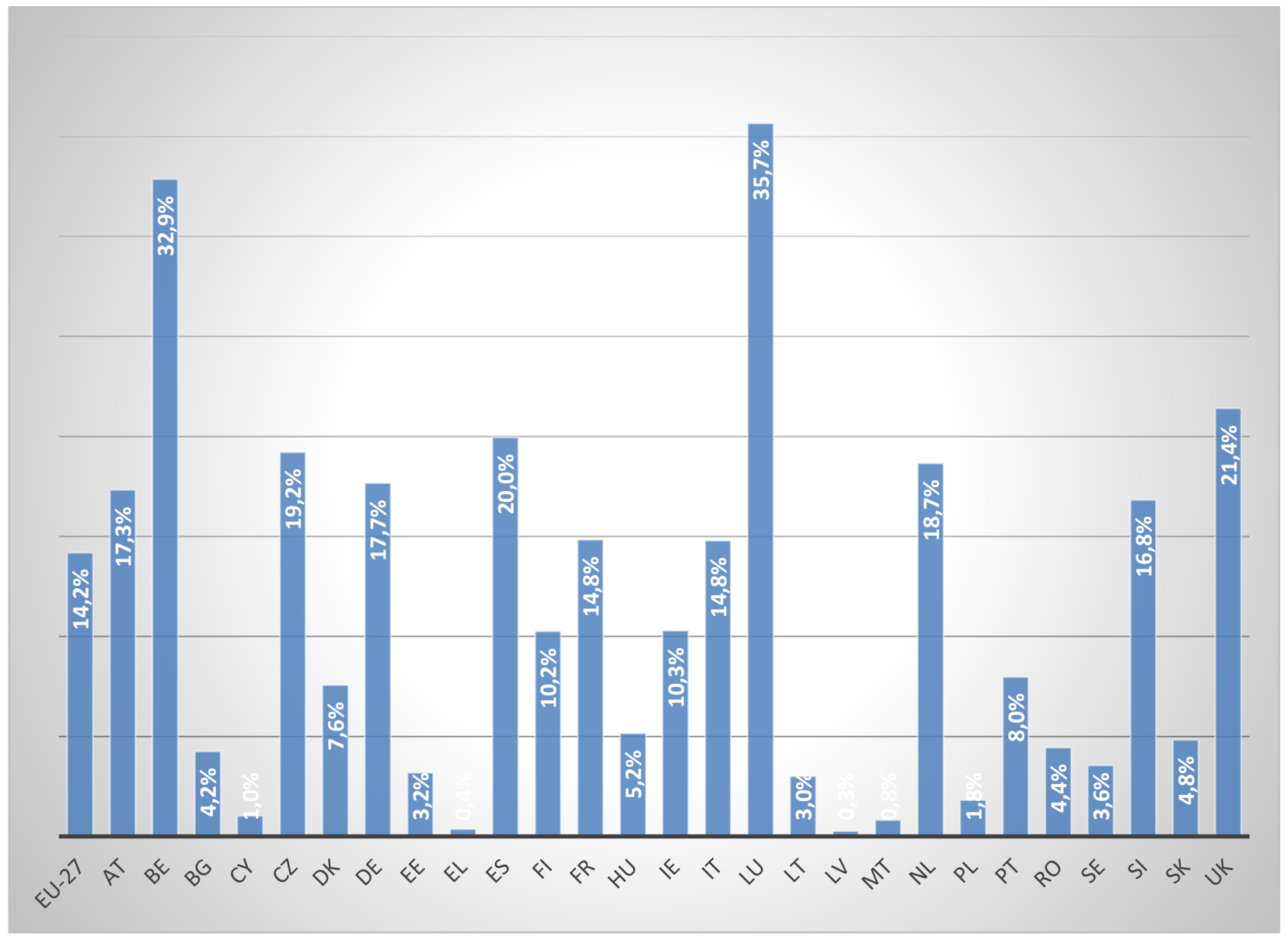

Data: European Commission (2013); own calculations.

\subsection{Additionality of public innovation support in Europe}

Czarnitzki et al. (2011), Duguet (2004) and Grossman et al. (1994) find general reasons why private companies under-invest in innovation activities, citing the uncertainty of success and the characteristics of a public good.

Every Member State offers public innovation support, as well as the EU itself and many subnational jurisdictions. Furthermore, recent studies show differences between the different political levels (Fernández-Ribas 2009; Busom and Fernández-Ribas 2007; Becker 2013).

All studies for the EU and its Member States show partial or complete additionality of public support, which at least means that public support does not completely crowd out private 
investment in R\&D and innovation. ${ }^{3}$ Duguet (2004) for France, Aerts and Czarnitzki (2004) for Belgium and Czarnitzki and Fier (2002) as well as Lehmann and Stierwald (2004) for Germany show the additionality of public innovation support. Furthermore, Busom (2000) for Spain and Görg and Strobl (2007) for Ireland stress that crowding-out can be ruled out at least for several companies - e.g. domestic firms that received small grants in Ireland - while these two studies do not completely rule out crowding-out. Krohmer's (2010) meta-analysis of 57 studies focusing on R\&D support in Germany also shows no general crowding-out of private investments. Thus, this paper assumes at least partial additionality and at most partial crowding-out in the EU.

Outside the EU, Wallsten (2000) shows crowding-out in the United States, whereas Levy (1990) and Hall and van Reenen (2000) find different results. Hall and van Reenen (2000) describe that one dollar of public innovation support generates one additional dollar of private investment in North America. For state programmes in the USA, Atkinson (1991) finds differences in the effectiveness between states; for instance, it is higher in Michigan and Pennsylvania compared with Illinois and Massachusetts.

Regarding the private investment induced, a similar study by Fier and Czarnitzki (2005) for Germany shows a smaller effect of $€ 0.28$ of private investment induced by one euro of public spending. By contrast, Hussinger (2008) also finds a complete additionality of R\&D for the German manufacturing sector, whereby one euro of public subsidies on R\&D stimulates another euro of private $R \& D$ investment.

A recent study by Radicic and Pugh (2013) shows that public institutions face a selection problem, which reduces the positive effect of public innovation support. Public institutions have a tendency towards a 'picking the winner' strategy to evade information problems about the firms applying for innovation support, as Cantner and Kösters (2012) outline. These factors reduce additionality and thus lead to a greater degree of crowding-out.

Nonetheless, regarding additionality, the empirical results in Europe present a clear picture that public innovation support induces additional private innovative activities and crowding-out is at least not a general problem.

\footnotetext{
${ }^{3}$ Despite not always being synonymously used, for this study R\&D spending and innovation spending can be perceived synonymously. For the differences compare the Oslo, OECD (1997), and Frascati, OECD (2002), manuals of the OECD or for a (German) definition of R\&D also Haverkamp (2007).
} 


\subsection{Effectiveness measures of public support}

With respect to the effectiveness of public innovation support, a first indicator of the effects towards the entire society is defined with the social rate of return (Griliches 1992). Nonetheless, this indicator remains very abstract and difficult to implement empirically.

A comparison of different innovative support schemes - such as between Finland and Germany in Czarnitzki et al. (2007) - also shows effects of public innovation support on R\&D activity similar to those mentioned in section 2.2.

Clausen (2009) distinguishes between 'far from the market' (research) and 'close to the market' (development), concluding that support 'far from the market'stimulates private R\&D more strongly and with a higher social rate of return (Clausen 2009).

Regarding the effect on a company's sales, Hussinger (2008) shows a positive effect of both R\&D efforts in general and publicly induced $R \& D$ efforts on the new product sales of a company in Germany.

For Finland, Lehtoranta analyses the growth pattern and labour productivity of firms supported by the 'Tekes' programme, suggesting that public innovation support positively influences both the growth pattern (Lehtoranta 2000) and labour productivity (Lehtoranta 2000). In the same book, Maliranta (2000b) finds a less clear effect on productivity growth in general: while he highlights a positive effect at the industry level, the observations of one period had to be removed as outliers before finding a positive effect.

SMEs particularly benefit from industry-specific R\&D support (Maliranta 2000a). Job creation is only supported for private R\&D, while the effect for publicly-financed R\&D is 'ambiguous' (Maliranta 2000a). A recent paper by Pajarinen and Rouvinen (2014) ${ }^{4}$ summarizes that the effect of 'Tekes' on labour productivity has been rejected by more recent studies, although the authors strongly criticize the approach of such studies.

As another factor of effectiveness, Afcha and García-Quevedo (2014) analyse the development of employees working in R\&D. They find a positive influence in general but no significant effect for regional subsidies in Spain.

Bogliacino et al. (2014) adopt a broader perspective on labour effects, analysing the labour effect in general, rather than restricted to $R \& D$ employees. For a relatively small sample of 677 European firms, they emphasize that service and high-tech sectors show stronger effects, in contrast to no effect in traditional manufacturing. They find a small yet significant effect of R\&D investment

\footnotetext{
4 Unfortunately, the report itself is only available in Finnish (apart from the abstract) but based upon the abstract, correspondence with the authors and translation programmes, the work of the paper is summarized here.
} 
increasing a company's employment, but they also argue that process innovations are generally labour-unfriendly.

Analysing the development turnover and return on sales, Becker (2013) finds unclear results for the influence of public innovation support granted by the state and the European level in Germany (see Table 2). A positive impact is only clearly supported at the federal level.

Generally, the empirical evidence shows a certain ambiguity and mainly small effects are detected independent of the indicator. Aside from one study that uses a very small dataset, none of the studies analyses the EU as a broader entity. As indicators, labour productivity in Finland, sales in Germany or employees in Spain or Europe form an interesting basis for the further analysis of competitiveness. 
Table 2: Effects of public support on turnover and return on sales (logistic regressions, logit)

\begin{tabular}{|c|c|c|c|c|c|c|c|c|c|c|c|c|c|c|c|c|c|c|c|c|}
\hline & \multicolumn{5}{|c|}{ Turnover rise (turnup) } & \multicolumn{5}{|c|}{ Turnover fall (turndown) } & \multicolumn{5}{|c|}{ Return on sales rise (rosup) } & \multicolumn{5}{|c|}{ Return on sales fall (rosdown) } \\
\hline & Coef. & $\begin{array}{l}\text { Std. } \\
\text { Err. }\end{array}$ & & $\begin{array}{l}\text { Odds } \\
\text { Ratio }\end{array}$ & & Coef. & $\begin{array}{l}\text { Std. } \\
\text { Err. }\end{array}$ & & $\begin{array}{l}\text { Odds } \\
\text { Ratio }\end{array}$ & & Coef. & $\begin{array}{l}\text { Std. } \\
\text { Err. }\end{array}$ & & $\begin{array}{l}\text { Odds } \\
\text { Ratio }\end{array}$ & & Coef. & $\begin{array}{l}\text { Std. } \\
\text { Err. }\end{array}$ & & $\begin{array}{l}\text { Odds } \\
\text { Ratio }\end{array}$ & \\
\hline suppst & -0.1640 & 0.1139 & & 0.8487 & & 0.2316 & 0.1156 & ** & 1.2606 & ** & 0.0015 & 0.1304 & & 1.0015 & & 0.0758 & 0.1796 & & 1.0787 & \\
\hline suppfe & 0.6039 & 0.1116 & $* \star *$ & 1.8292 & *** & -0.6078 & 0.1152 & *** & 0.5445 & *** & 0.5279 & 0.1158 & $* \star *$ & 1.6954 & 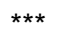 & 0.1483 & 0.1661 & & 1.1599 & \\
\hline suppeu & 0.2172 & 0.1499 & & 1.2426 & & -0.2123 & 0.1539 & & 0.8087 & & 0.2907 & 0.1696 & * & 0.7477 & * & -0.2406 & 0.2417 & & 0.7861 & \\
\hline cons & 0.3614 & 0.0278 & $* * *$ & 1.4354 & $\star \star *$ & -0.5254 & 0.0283 & $* * *$ & 0.5913 & $* * *$ & $1.3857^{-}$ & 0.0341 & $* * *$ & 0.2501 & $* * *$ & -2.2453 & 0.0464 & $* * *$ & 0.1059 & $\star \star * *$ \\
\hline$L R \operatorname{chi}^{2}(3)$ & 43.87 & & & & & 40.13 & & & & & 22.44 & & & & & 1.67 & & & & \\
\hline Prob $>$ chi $^{2}$ & 0.0000 & & & & & 0.0000 & & & & & 0.0001 & & & & & 0.6442 & & & & \\
\hline Pseudo $R^{2}$ & 0.0054 & & & & & 0.0050 & & & & & 0.0036 & & & & & 0.0004 & & & & \\
\hline
\end{tabular}

Data: ZEW MIP 2007; Notes: Calculated with Stata (2014); ${ }^{* \star *}$ denotes significance at $1 \%$ level; ${ }^{* *}$ at $5 \%$ level; ${ }^{*}$ at $10 \%$ level.

Source: Becker (2013). 


\section{Hypotheses}

While existing studies have addressed different aspects of public innovation support, this study focuses on effectiveness. For this purpose, the study considers different aspects of competitiveness in a European context:

\section{Hypothesis 1: R\&D investment increases a firm's competitiveness.}

Although political actors claim increased competitiveness to be one main aim of public innovation support (Atkinson 1991), the effect is unclear in other studies (González Cerdeira and Pazó Martínez 2008). A detailed analysis of different aspects is necessary, as Maliranta (2000b) claims that 'the return to $R \& D$ seems to be clearly negative for medium-sized firms only', whereas Lang (2009) suggests that 'recent data seems to confirm the positive effect of research input on productivity dynamics'.

Therefore, positive average treatment effects of the treatment is expected.

\section{Hypothesis 2: Public support for private R\&D investment increases a firm's competitiveness.}

Public innovation support is justified through potential under-investment in R\&D due to the problem of uncertainty and the non-excludability of the results of successful innovation projects. Therefore, reducing under-investment results in increased competitiveness for the company supported. Moreover, other influences also have to be considered, including the general market surrounding and the situation in a country.

All countries with public innovation support claim the aim of fostering their innovativeness and the competitiveness of their economies by supporting R\&D. Therefore, an effect at the micro-level is a necessary precondition for achieving the aims at the macro-level. Maliranta (2000a) ascertains that 'manufacturing firms supported by Tekes have been able to create jobs in net terms at a considerable rate since 1994', thus supporting this hypothesis.

A positive yet smaller effects of the public support variables in the regressions is expected.

\section{Hypothesis 3: Different countries achieve different levels in their effectiveness of public innovation support.}

Resulting from hypothesis 3, as well as different support schemes and innovative frameworks in the different EU Member States, differences between countries exist, including in the effectiveness of public innovation support. One such example of a difference is between Luxembourg and 
Portugal, which are the countries that, in recent years, have seen the highest increase in public R\&D support: while Luxembourg already had a very high level of public innovation support, Portugal has merely built up its innovation support from scratch in recent years. Moreover, while Luxembourg only has half a million inhabitants and about 2,500 square kilometres, Portugal has 10.5 million inhabitants and a land area of more than 92,000 square kilometres. These factors prompt different effects, which influence the effectiveness of innovation support. For example, the control of public support is easier in Luxembourg, increasing the effect in comparison with Portugal, whereas the variety of firms supported is probably higher in a larger country with a more diversified economy, which creates a positive effect for Portugal compared with Luxembourg - in addition to other country effects.

Accordingly significantly different dummy variables for at least some of the participating countries are expected.

\section{Data and methods}

\subsection{Data}

Eurostat's CIS offers the possibility to use harmonized data ${ }^{5}$ for the relevant EU Member States. I use data from the 2008 data wave, which include more variables concerning the total amount of R\&D spending in a firm compared with later data waves. Regarding the questions mentioned, the dataset uses data from almost all the countries mentioned above that offer public innovation support. Some countries such as Cyprus, Finland, Italy or Sweden are dropped due to having either missing data or data that are not harmonized. Problems in the harmonization of the CIS are well described in Mairesse and Mohnen (2010), prompting the need for stronger harmonization, at least for some core variables. Additionally, firms complete the CIS questionnaire subjectively, which also creates problems (Mairesse and Mohnen 2010).

As the CIS is an unbalanced panel, ${ }^{6}$ the analysis uses the data as cross-sectional data. Nonetheless, the variables for turnover and the number of employees are included lagged from both 2006 and 2008. Although this is not a classical lag by a panel, the questionnaire includes a question concerning the same figures from two years before. However, these two variable pairs are used to calculate differences in turnover and employee numbers, as well as labour productivity. The sample comprises 29,451 firms.

\footnotetext{
${ }^{5}$ For details see OECD (1997).

${ }^{6}$ In an unbalanced panel a firm might be dropped in one year after participating earlier in the panel and might return in a later year.
} 
Table 3: Summary characteristics of variables by reception of public innovation support

\begin{tabular}{lrrrr}
\hline & Untreated (fungen=0 ) & \multicolumn{3}{c}{ Treated (fungen=1) } \\
\hline & Mean & \multicolumn{1}{c}{ Std. Dev. } & Mean & \multicolumn{1}{c}{ Std. Dev. } \\
\hline fungen & 0.000 & 0.000 & 1.000 & 0.000 \\
regular & 0.363 & 0.481 & 0.617 & 0.486 \\
Inrdexp & 11.574 & 2.044 & 12.676 & 1.957 \\
sme & 0.495 & 0.500 & 0.514 & 0.500 \\
centralist & 0.524 & 0.499 & 0.321 & 0.467 \\
federal & 0.068 & 0.252 & 0.057 & 0.231 \\
dturnover & 9980330 & -140000000 & 18000000 & 280000000 \\
dempl & -4.890 & 1098.789 & 6.514 & 618.738 \\
dturnemp & 24575.570 & 724273.100 & 34277.310 & 716845.500 \\
pdinno & 0.721 & 0.449 & 0.749 & 0.434 \\
psinno & 0.735 & 0.441 & 0.735 & 0.441 \\
orinno & 0.599 & 0.490 & 0.642 & 0.480 \\
mrinno & 0.467 & 0.499 & 0.457 & 0.498 \\
turnmar & 0.093 & 0.197 & 0.131 & 0.237 \\
turnin & 0.138 & 0.243 & 0.144 & 0.243 \\
\hline
\end{tabular}

Data: Eurostat CIS microdata 2008; Notes: Calculated with Stata (2014).

\subsection{Propensity score matching}

With data from a non-experimental setting, the assumption of randomness is questionable, as mentioned by Klette et al. (2000):

'Given the many factors involved in the political economy process that determines the allocation of $R \& D$ subsidies, random allocation may not be too misleading in some cases. However, assuming that governments' deliberate selection process is largely random is clearly dubious and there might be a significant bias involved in the estimated impact parameters.'

These problems are mentioned by other authors, including Blanes and Busom (2004), González Cerdeira and Pazó Martínez (2008), Almus and Czarnitzki (2003), Görg and Strobl (2007) or more generally by Wooldridge (2013).

Additionally, Radicic and Pugh (2013) find the problem of 'cherry picking', which will further reduce the randomness. Accordingly, the institutions granting public support often pick those firms that have a higher likelihood of becoming a successful example (see also Cantner and Kösters 2012). Methodologically, the approach of Becker (2013) has to be expanded by measures to reduce the potential problems of biased data. Due to the relatively high number of observations in the CIS, a control group of not-supported yet innovatively active firms can be created to test not only for hard factors, but also for some softer, less-observable ones. I apply propensity score matching (nearest 
neighbour matching) to find companies similar to those supported. ${ }^{7}$ With a structural probit estimation on the support as the dependent variable and several controls as independent variables, propensity scores are calculated and used to find a firm with no public innovation support with similar firm characteristics. During this matching, the average treatment effects of the treated (ATTs) are also calculated with Leuven and Sianesi (2003). Czarnitzki et al. (2007) show that due to the lack of potential instrumental variables as well as longitudinal panel data, propensity score matching is a reliable approach using CIS data.

\subsection{OLS regression}

In addition to these treatment effects, I study the influencing factors on turnover, employment and labour productivity development.

For this analysis, I run an ordinary least squares regression (OLS) on the differences of the three aforementioned variables with several firm characteristics as explanatory variables. As all three variables are continuously available in the dataset, I do not reduce them to dummy variables but rather calculate the differences. The coefficients are highly different due to the very different scales of turnover, the number of employees and labour productivity (as turnover per employee), although the effects become visible.

In order to reduce the problems mentioned in the previous sub-section, the weights calculated during the propensity score matching are implemented to weight the OLS regression. When an observed firm is the nearest neighbour for not only one but several other firms in the sample, its impact is higher in both the propensity score matching process and the OLS. This increases the robustness of the OLS regression but reduces some of the coefficients.

\subsection{Variables}

Due to data restrictions, I focus on three dependent variables. In line with earlier studies, the development of turnover (dturnover, difference to the reference period in euro) and the number of employees (dempl, difference to the reference period in employee numbers) are analysed. Based upon these two variables, I calculate the labour productivity as turnover per employee, ${ }^{8}$ including its differences between 2006 and 2008 (dturnemp, difference to the reference period in euro per employee). The differences are calculated to show whether a positive or negative development is found, as well as the amplitude of this development across the two years.

\footnotetext{
${ }^{7}$ For a brief summary of different approaches to reducing the bias, see Hussinger (2008).

${ }^{8}$ Authors including Koski and Pajarinen (2014) and Pajarinen and Rouvinen (2014) use value added per employee. However, these data are not available in the CIS at the European level.
} 
The effect of R\&D on productivity reflects an inverted U-shaped curve, as Lang (2009) ascertained. Therefore, the effect of $R \& D$ activities has to be examined with a time lag, which is included in the dataset by measuring the activities in the last two years with two different variables in the general cross-sectional data. These lags should further mitigate the problem of endogeneity (Lee 2011).

Possible influences and thus explanatory variables are public R\&D support (fungen, dummy variable) and regular $R \& D$ activities (regular, dummy variable). In particular, the funding variable is underestimated in the OLS due to the previous propensity score matching, in which the variable formed the dependent variable of the structural model.

Firm and market characteristics are included, such as R\&D expenditure (Inrdexp, in order to be comparable with earlier studies in logarithms), company size (sme, dummy variable) and international ownership (foreign, dummy variable).

After a first version with dummy variables for centralist political systems (centralist, federal, dummy variables, reference variable semfed), I test for country-specific effects ( $B G, C Z, E E, E S, F R, H U$, $L T, L U, L V, N L, P T, R O, S I, S K$, dummy variables, reference variable $D E)$ and provide further details, especially compared with the general set of variables with only political system dummy variables. 
Table 4: Average treatment effects (Propensity score matching, nearest neighbour matching)

\begin{tabular}{|c|c|c|}
\hline & $\begin{array}{l}\text { Matching with } \\
\text { political system } \\
\text { dummies }\end{array}$ & $\begin{array}{l}\text { Matching with country } \\
\text { dummies }\end{array}$ \\
\hline & ATT & $A T T$ \\
\hline & (Std. Err.) & (Std. Err.) \\
\hline \multirow{2}{*}{ dturnover } & -8544464.73 & -10386210.2 \\
\hline & (5191538.18) & $(5036436.11)$ \\
\hline \multirow[t]{2}{*}{ dempl } & -17.3353 & -10.5085 \\
\hline & (7.4442) & $(8.7330)$ \\
\hline \multirow[t]{2}{*}{ dturnemp } & $3570.1983 x$ & 23624.6210 \\
\hline & (18825.0709) & $(10256.3847)$ \\
\hline \multirow[t]{2}{*}{ pdinno } & $0.0015 x$ & 0.0108 \\
\hline & $(0.0091)$ & $(0.0092)$ \\
\hline \multirow[t]{2}{*}{ psinno } & $-0.0004 * *$ & -0.0064 \\
\hline & $(0.0091)$ & $(0.0091)$ \\
\hline \multirow[t]{2}{*}{ orinno } & 0.0168 & 0.0269 \\
\hline & $(0.0101)$ & $(0.0101)$ \\
\hline \multirow[t]{2}{*}{ mrinno } & -0.0097 & -0.0117 \\
\hline & $(0.0104)$ & $(0.0103)$ \\
\hline \multirow[t]{2}{*}{ turnmar } & 0.0183 & 0.0182 \\
\hline & $(0.0046)$ & $(0.0045)$ \\
\hline \multirow[t]{2}{*}{ turnin } & -0.0028 & -0.0072 \\
\hline & $(0.0052)$ & $(0.0052)$ \\
\hline
\end{tabular}

Data: CIS microdata 2008; Notes: Calculated with Stata (2014) and Leuven and Sianesi (2003), Std. Err. does not take into account that the propensity score is estimated; ${ }^{* \star *}$ denotes significance at $1 \%$ level; ${ }^{* *}$ at $5 \%$ level; ${ }^{*}$ at $10 \%$ level, $x$ as mentioned in the text close to significance. 
Table 5: Influence of firm characteristics on differences in turnover, employees and labour productivity (weighted OLS)

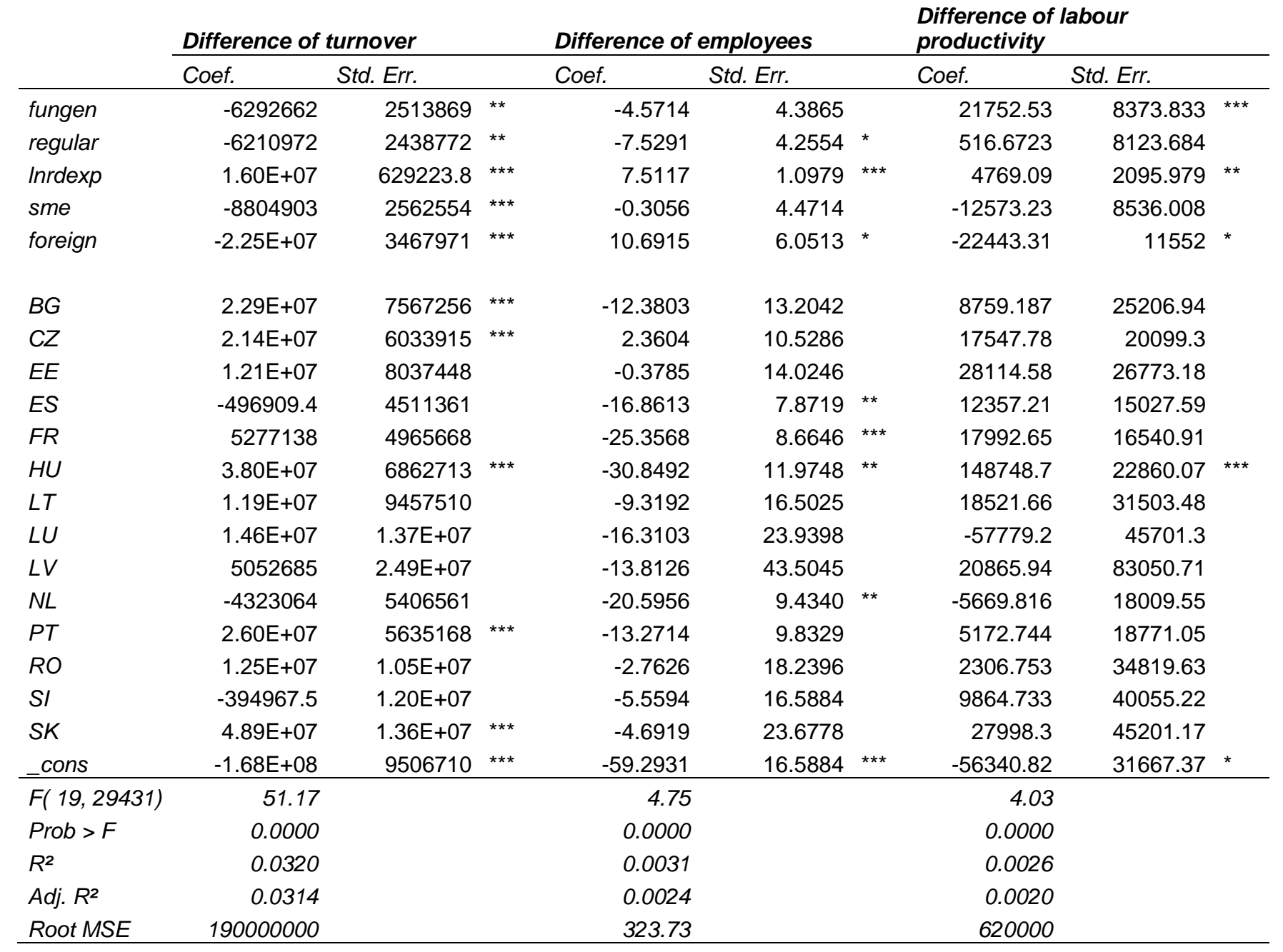

Data: Eurostat CIS microdata 2008; Notes: Calculated with Stata (2014) after propensity score matching with Leuven and Sianesi (2003), observations are weighted with the weights of the matching process; ${ }^{* \star *}$ denotes significance at $1 \%$ level; ${ }^{\star *}$ at $5 \%$ level; ${ }^{*}$ at $10 \%$ level. 


\section{$5 \quad$ Results}

The estimations provide ambiguous results: while the average treatment effects for all tested variables are insignificant, several firm characteristics show significant influences on the different measures of competitiveness.

However, the influences on the ATTs reported in Table 4 are unclear: regarding the three competitiveness indicators, the effects are negative for turnover and employment and positive for labour productivity, although none is significant. The same is true for the variables indicating whether a firm introduced a new product (or service), process, organizational procedure or market innovation, as well as the turnover of new-to-the-market and new-to-the-firm innovations. The ATTs for product (and service) and organizational innovations are positive but not significant, while the ATTs for process and marketing innovations as well as the ATTs for turnover of new-to-themarket or new-to-the-firm products are negative and not significant.

The general insignificance only shows in the tests with country dummies to reduce country-specific effects. By contrast, in a second version with explanatory variables for political systems, a negative ATT on process innovations turns significant at the 5 per cent level, while labour productivity and the likelihood of a new product innovation are close to significance (and both positive). All other ATTs remain (highly) insignificant.

Nonetheless, I observe effects of the explanatory variables in the OLS regressions (Table 5, page 103) on the development of the three competiveness indicators.

All five explanatory variables and several country dummies significantly influence the differences in turnover between 2006 and 2008, whereby the reception of public funding strongly reduces the turnover by more than $€ 6$ million. Furthermore, I also examine similar findings for companies that regularly undertake $R \& D$ activities. By contrast, the coefficient for firms that invest more money in R\&D marks a higher turnover, while the coefficients for SMEs and foreign-owned companies show lower turnovers after the two years. Both coefficients are higher than the first effects, with $€ 8$ million for SMEs and €22 million for foreign companies. Country effects on turnover strongly influence Bulgaria, the Czech Republic, Hungary, Portugal and the Slovak Republic.

In the second regression on the change in the number of employees, I recognize weak significance for a negative coefficient of regularity, indicating a reduction of 7.5 employees, and a positive coefficient for foreign-owned companies, marked by an increase of 10.7 employees. The effect of the R\&D expenditure is positive and highly significant, indicating that a one percent increase in $R \& D$ expenditure increases the number of employees by 0.075 , while the negative coefficients for 
funding and SMEs are insignificant. Country-specific employment effects are evident for Spain, France, Hungary and the Netherlands.

The third regression provides the following results for labour productivity, with productivity measured as the change in turnover per employee between 2006 and 2008.

With a coefficient of almost $€ 22,000$ per employee, the reception of public innovation support shows a highly significant and positive coefficient. As in the two previous regressions, R\&D expenditure shows a positive and significant (at a 5 per cent level) coefficient. By contrast, the weakly significant coefficient for foreign-owned firms is negative, with slightly above $€ 22,000$ per employee. Only the country effect for Hungary proves significant in this regression. ${ }^{9}$

It is important to mention that the explanatory power of the OLS regressions is very low, which is unsurprising given that other factors have a much stronger impact on turnover, employment and labour productivity development compared with my explanatory variables. The explanatory power is further reduced by the combination with the matching approach, while the non-significance of the ATTs also supports these findings. Nonetheless, part of these variables influences the competitiveness measures and thus reflects one possible instrument for policy makers.

\section{Conclusion}

Owing to the ambiguous results, drawing conclusions is somewhat difficult. For instance, the presented analysis shows no significant effects of public innovation support on the average treatment effects, leading to a rejection of the hypotheses (especially hypothesis 2), although significant coefficients in the OLS regression, support at least partially the hypotheses.

While the regularity of $R \& D$ does not show clear influences on the three indicators of competitiveness, the amount of money spent on innovative activities always has a positive and significant influence; accordingly, a firm with more money spent on innovations has a higher turnover, more employees and a higher labour productivity, thus supporting hypothesis 1 .

The effect of public innovation support mentioned in hypothesis 2 is mixed: while it shows a negative and significant coefficient for the turnover development, whereby companies that received public innovation support ceteris paribus show lower turnover differences, the effect on employment is not significant (but also negative). By contrast, the coefficient for public innovation support in the regression on the differences of labour productivity is highly significant and positive. The results reveal a positive effect on labour productivity, although negative effects on

\footnotetext{
9 This means that all three country coefficients are only significant for Hungary. However, their validity is doubtful as the coefficients show different directions and dubious values.
} 
employment and turnover. In terms of competitiveness, firms receiving public support can be seen as more efficient due higher labour productivity, although declining turnovers can also be seen as an indicator for a negative trend in the market. Therefore, my results regarding hypothesis 2 are ambiguous and thus this hypothesis is to be rejected.

With respect to the country effects, different countries show different results; however, as the effects vary between the different regressions and - apart from Hungary - no country shows statistically significant effects in all three estimations, the effect is unclear. Nonetheless, differing country-specific effects exist and thus hypothesis 3 cannot be rejected, but is weakly supported. It is important to mention that the results of my OLS regressions with their low $R^{2}$ values have to be considered carefully: regarding the development of employees and labour productivity - as well as turnover development, to a lesser extent - other indicators have stronger impacts. Nonetheless, the public support programmes are one common tool that policy makers often use across Europe. Moreover, the European analysis shows that there are indicators for the effectiveness of public innovation support programmes that extend beyond the literature on additionality. However, further research at both the European and the national levels is required, as the results are ambiguous and only show weak influences on competitiveness.

For policy makers, this prompts the need to evaluate innovation support more closely, focusing on the original objectives, namely supporting companies that face barriers to innovate (FernándezRibas 2009; Becker and Bizer 2015) the effects on competitiveness have to be addressed both in the policy making process and later in the accountability of institutions that grant support. However, these two objectives might also enter into conflict, given that while it is positive for the aim of effectiveness to focus on larger and generally more successful companies that already have an advantage, such a policy would clearly reduce the opportunities for companies such as SMEs with barriers to innovate to participate in innovation support.

This leads us to the question of political preferences and different programmes at different political levels. As economists, it is not our role to decide upon this question, but a higher transparency in the targets - and their conflicts - of support programmes and their deployment would help to simplify the decision-making process of policy makers, thus increasing the transparency of the process. 


\section{Acknowledgements}

This paper is based upon data from the Eurostat CIS 2008. The responsibility for all conclusions drawn from the data lies entirely with the author.

Thanks to Prof. Dr. Kilian Bizer, Prof. Dr. Markus Spiwoks and the PhD students for their input during two seminars at the Georg-August-University in Göttingen for their feedback. I also thank Prof. Jeffrey M. Wooldridge, PhD for his very valuable comment to the matching process (and see insights before at a summer school on advanced econometrics). Further thanks to Prof. Dr. Hanna Hottenrott for her general remarks on the language of this paper. Special thanks also to Eurostat and especially Geneviève Villette for the possibilities at the Safe Centre in Luxembourg. Additionally, I am grateful to all those who checked this paper for linguistic errors.

This work was supported by the German Bundesministerium für Bildung und Forschung (BMBF) via Friedrich-Naumann-Stiftung für die Freiheit (FNF) [ST 6754 / P 622]. 


\section{Appendix}

Table A1: Development of the relative share of public support of R\&D (\&I) to total public aid in the EU, 2007-2012

\begin{tabular}{|c|c|c|c|c|c|c|c|}
\hline & 2007 & 2008 & 2009 & 2010 & 2011 & 2012 & Difference 2012-2007 \\
\hline$E U-27$ & $12.29 \%$ & $12.50 \%$ & $14.62 \%$ & $15.60 \%$ & $15.68 \%$ & $14.49 \%$ & $2.20 \%$ \\
\hline BE & $35.28 \%$ & $34.45 \%$ & $37.89 \%$ & $45.23 \%$ & $21.83 \%$ & $22.50 \%$ & $-12.78 \%$ \\
\hline BG & $4.25 \%$ & $2.89 \%$ & $6.72 \%$ & $6.07 \%$ & $3.48 \%$ & $2.08 \%$ & $-2.17 \%$ \\
\hline CY & $1.99 \%$ & $0.90 \%$ & $0.18 \%$ & $1.50 \%$ & $0.44 \%$ & $1.14 \%$ & $-0.85 \%$ \\
\hline CZ & $18.20 \%$ & $14.74 \%$ & $23.02 \%$ & $21.31 \%$ & $20.30 \%$ & $17.68 \%$ & $-0.52 \%$ \\
\hline DK & $3.87 \%$ & $7.58 \%$ & $6.57 \%$ & $9.33 \%$ & $9.92 \%$ & $8.12 \%$ & $4.26 \%$ \\
\hline DE & $14.57 \%$ & $14.30 \%$ & $14.67 \%$ & $18.42 \%$ & $25.05 \%$ & $18.98 \%$ & $4.41 \%$ \\
\hline EE & $7.07 \%$ & $7.62 \%$ & $2.63 \%$ & $1.33 \%$ & $0.23 \%$ & $0.18 \%$ & $-6.89 \%$ \\
\hline EL & $0.75 \%$ & $0.74 \%$ & $0.36 \%$ & $0.08 \%$ & $0.08 \%$ & $0.21 \%$ & $-0.53 \%$ \\
\hline ES & $14.46 \%$ & $16.17 \%$ & $24.91 \%$ & $23.36 \%$ & $21.48 \%$ & $19.38 \%$ & $4.91 \%$ \\
\hline FI & $8.00 \%$ & $12.30 \%$ & $11.47 \%$ & $11.56 \%$ & $9.48 \%$ & $8.69 \%$ & $0.69 \%$ \\
\hline FR & $18.26 \%$ & $13.89 \%$ & $14.66 \%$ & $12.49 \%$ & $15.66 \%$ & $14.07 \%$ & $-4.19 \%$ \\
\hline HU & $0.53 \%$ & $3.37 \%$ & $6.14 \%$ & $1.47 \%$ & $4.43 \%$ & $15.01 \%$ & $14.49 \%$ \\
\hline IE & $9.99 \%$ & $4.82 \%$ & $9.56 \%$ & $14.34 \%$ & $12.18 \%$ & $10.87 \%$ & $0.87 \%$ \\
\hline IT & $10.07 \%$ & $15.53 \%$ & $18.36 \%$ & $13.58 \%$ & $13.25 \%$ & $17.98 \%$ & $7.91 \%$ \\
\hline LU & $23.71 \%$ & $26.41 \%$ & $51.53 \%$ & $43.72 \%$ & $25.12 \%$ & $43.50 \%$ & $19.79 \%$ \\
\hline LT & $0.00 \%$ & $0.05 \%$ & $2.65 \%$ & $7.08 \%$ & $3.77 \%$ & $4.48 \%$ & $4.48 \%$ \\
\hline LV & $0.08 \%$ & $0.52 \%$ & $0.08 \%$ & $0.16 \%$ & $0.47 \%$ & $0.25 \%$ & $0.17 \%$ \\
\hline MT & $0.04 \%$ & $0.01 \%$ & $1.71 \%$ & $0.24 \%$ & $2.17 \%$ & $0.72 \%$ & $0.69 \%$ \\
\hline NL & $12.28 \%$ & $11.87 \%$ & $18.62 \%$ & $25.20 \%$ & $24.94 \%$ & $19.03 \%$ & $6.74 \%$ \\
\hline PL & $2.30 \%$ & $1.19 \%$ & $1.09 \%$ & $2.08 \%$ & $0.89 \%$ & $3.42 \%$ & $1.12 \%$ \\
\hline PT & $0.85 \%$ & $1.14 \%$ & $2.99 \%$ & $12.00 \%$ & $8.13 \%$ & $22.75 \%$ & $21.90 \%$ \\
\hline RO & $3.01 \%$ & $7.39 \%$ & $3.43 \%$ & $11.11 \%$ & $0.70 \%$ & $1.03 \%$ & $-1.97 \%$ \\
\hline SE & $2.84 \%$ & $3.36 \%$ & $4.23 \%$ & $3.69 \%$ & $3.47 \%$ & $3.71 \%$ & $0.87 \%$ \\
\hline
\end{tabular}




\begin{tabular}{lrrrrrrr}
\hline & 2007 & 2008 & 2009 & 2010 & 2011 & 2012 & Difference 2012-2007 \\
\cline { 2 - 9 } SI & $11.00 \%$ & $8.61 \%$ & $18.31 \%$ & $26.71 \%$ & $18.54 \%$ & $17.83 \%$ & $6.83 \%$ \\
SK & $1.64 \%$ & $1.02 \%$ & $2.81 \%$ & $6.03 \%$ & $8.44 \%$ & $9.03 \%$ & $7.39 \%$ \\
UK & $18.74 \%$ & $20.67 \%$ & $23.36 \%$ & $24.98 \%$ & $22.00 \%$ & $18.73 \%$ & $-0.01 \%$ \\
\hline Data: European Commission (2013); own calculations. & & & & & &
\end{tabular}




\section{References}

Aerts K, Czarnitzki D (2004) Using Innovation Survey Data to Evaluate R\&D Policy: The Case of Belgium. ZEW Discussion Paper, Mannheim

Afcha S, García-Quevedo J (2014) The impact of R\&D subsidies on R\&D employment composition.

http://www.ieb.ub.edu/index.php?option=com_phocadownload\&view=category\&download=4 72\&id $=3 \&$ Itemid $=110$

Almus M, Czarnitzki D (2003) The effects of public R\&D subsidies on firms' innovation activities: The case of Eastern Germany. Journal of business \& economic statistics : JBES ; a publication of the American Statistical Association 21(2):226-236

Asplund R (ed) (2000) Public R \& D funding, technological competitiveness, productivity, and job creation. Etla. B, vol 168. Taloustieto, Helsinki

Atkinson RD (1991) Innovation policy making in a federalist system: Lessons from the states for U.S. federal innovation policy making. Research Policy 20(6):559-577. doi: 10.1016/00487333(91)90046-S

Becker L (2013) No gains of federalism in innovation support?: The case of Germany. In: DRUID society (ed) Conference Proceedings 35th DRUID Celebration Conference 2013. online

Becker L, Bizer K (2015) Federalism and innovation support for small and medium-sized enterprises: Empirical evidence in Europe

Blanes JV, Busom I (2004) Who participates in R\&D subsidy programs?: The case of Spanish manufacturing firms. Research Policy 33(10):1459-1476

Bogliacino F, Piva M, Vivarelli M (2014) Technology and employment: The job creation effect of business R\&D

Busom I (2000) An Empirical Evaluation of the Effects of R\&D Subsidies. Economics of Innovation \& New Technology 9(2):111-149

Busom I, Corchuelo Martínez-Azúa B, Martínez Ros E (2012) Tax incentives or subsidies for R\&D? http://www.merit.unu.edu/publications/wppdf/2012/wp2012-056.pdf

Busom I, Fernández-Ribas A (2007) Do R\&D Programs of Different Government Levels Overlap in the European Union? In: Science, Technology and Innovation Policy, pp 1-5

Cantner U, Kösters S (2012) Picking the winner?: Empirical evidence on the targeting of R\&D subsidies to start-ups. Small Business Economics 39(4):921-936

Cerulli G (2010) Modelling and measuring the effect of public subsidies on business R\&D: A critical review of the econometric literature. The economic record : er 86(274):421-449

Clausen TH (2009) Do subsidies have positive impacts on R\&D and innovation activities at the firm level? Structural change and economic dynamics 20(4):239-253

Czarnitzki D, Ebersberger B, Fier A (2007) The relationship between R\&D collaboration, subsidies and R\&D performance: Empirical evidence from Finland and Germany. Journal of Applied Econometrics 22(7):1347-1366

Czarnitzki D, Fier A (2002) Do Innovation Subsidies Crowd Out Private Investment? Evidence from the German Service Sector. Applied Economics Quarterly (Konjunkturpolitik) 48(1):125

Czarnitzki D, Hanel P, Rosa JM (2011) Evaluating the impact of R\&D tax credits on innovation: A microeconomic study on Canadian firms. Research Policy 40(2):217-229

Duguet E (2004) Are R\&D subsidies a substitute or a complement to privately funded R\&D ? An econometric analysis at the firm level. Revue d'Economie Politique 114(2):245-274

European Commission (2013) State Aid Scoreboard 2013: Non-crisis aid

Eurostat Community Innovation Survey (CIS)

Fernández-Ribas A (2009) Public support to private innovation in multi-level governance systems: an empirical investigation. Science and Public Policy 36:457-467. doi:

10.3152/030234209X460953 
Fier A, Czarnitzki D (2005) Zum Stand der empirischen Wirkungsanalyse der öffentlichen Innovations- und Forschungsförderung.

http://www.zew.de/de/publikationen/evaluationinno/ZEW_Ueberblick_Wirkungsanalyse.pdf. Accessed 11 March 2015

González Cerdeira X, Pazó Martínez C (2008) Do public subsidies stimulate private R\&D spending? Research Policy 37(3):371-389

Görg H, Strobl E (2007) The Effect of R\&D Subsidies on Private R\&D. Economica 74(294):215234. doi: 10.1111/j.1468-0335.2006.00547.x

Griliches Z (1992) The Search for R\&D Spillovers. The Scandinavian Journal of Economics 94:29-47

Grossman GM, Helpman, Elhanan (1994) Endogenous Innovation in the Theory of Growth. The Journal of Economic Perspectives, 8(1):23-44

Hall B, van Reenen J (2000) How effective are fiscal incentives for R\&D? A review of the evidence. Research Policy 29(4 - 5):449-469

Haverkamp K (2007) Bestimmungsfaktoren der Vertragsforschung in Deutschland : eine theoretische und ökonometrische Analyse, Universität Göttingen

Hussinger K (2008) R\&D and subsidies at the firm level: An application of parametric and semiparametric two-step selection models. Journal of Applied Econometrics 23(6):729-747

Klette TJ, Møen J, Griliches Z (2000) Do subsidies to commercial R\&D reduce market failures?: Microeconometric evaluation studies. Research Policy 29(4/5):471-495

Koski H, Pajarinen M (2014) Subsidies, the shadow of death and labor productivity

Krohmer O (2010) Zur Verdrängungswirkung staatlicher FuE-Förderung. ifo Dresden berichtet 17(4):49-51

Lang G (2009) Measuring the returns of R\&D: An empirical study of the German manufacturing sector over 45 years. Research Policy 38(9):1438-1445

Lee C (2011) The differential effects of public R\&D support on firm R\&D: Theory and evidence from multi-country data. Technovation : the international journal of technological innovation, entrepreneurship and technology management 31(5/6):256-269

Lehmann H, Stierwald A (2004) Investitionsförderung in Ostdeutschland: Ergebnisse einer empirischen Wirkungsanalyse. Wirtschaft im Wandel 10(5):122-128

Lehtoranta $O$ (2000) Technology-based firms and public R\&D support: A descriptive introduction. In: Asplund R (ed) Public R \& D funding, technological competitiveness, productivity, and job creation. Taloustieto, Helsinki, pp 15-46

Leuven E, Sianesi B (2003) PSMATCH2: Stata module to perform full Mahalanobis and propensity score matching, common support graphing, and covariate imbalance testing

Levy DM (1990) Estimating the impact of government R\&D. Economics Letters 32(2):169-173

Mairesse J, Mohnen PA (2010) Using innovation surveys for econometric analysis. In: $\mathrm{Hall} \mathrm{BH}$, Rosenberg N (eds) Handbook of the economics of innovation. North Holland, Amsterdam [u.a.], pp 1129-1155

Maliranta M (2000a) Job creation by supporting technology advances?: Evidence from Finnish plants. In: Asplund R (ed) Public R \& D funding, technological competitiveness, productivity, and job creation. Taloustieto, Helsinki, pp 87-128

Maliranta M (2000b) Privately and publicly financed R\&D as determinants of productivity: Evidence from Finnish enterprises. In: Asplund R (ed) Public R \& D funding, technological competitiveness, productivity, and job creation. Taloustieto, Helsinki, pp 47-85

OECD (1997) Oslo manual : Proposed guidelines for collecting and interpreting technological innovation data, Paris

OECD (2002) Frascati manual 2002 : the measurement of scientific and technological activities; proposed standard practice for surveys of research and experimental development, Paris

OECD (2011) Regions and innovation policy. OECD reviews of regional innovation. OECD Publ., Paris 
OECD (2013) Measuring R\&D Tax Incentives: Main features of R\&D tax incentives provisions in selected OECD and non OECD countries, 2013

Pajarinen M, Rouvinen P (2014) Tekesin rahoituksen vaikutus työn tuottavuuteen. ETLA Raportit/ETLA Reports

Radicic D, Pugh G (2013) The impact of innovation support programmes on SME innovation in traditional manufacturing industries: an evaluation for seven EU regions. In: DRUID society (ed) Conference Proceedings DRUID Academy 2013. online

Stata (2014) Stata. StataCorp LP

Wallsten SJ (2000) The effects of government-industry R\&D programs on private R\&D: the case of the Small Business Innovation Research program. RAND Journal of Economics (RAND Journal of Economics) 31(1):82-100

Wooldridge J (2013) Panel Data Econometrics and Treatment Effect Estimation. Advanced Summer School in Economics and Econometrics, Rethymno, Greece

ZEW Mannheimer Innovation Panel (MIP) 
Kapitel 5

\title{
Föderalismus in der staatlichen Innovationsförderung
}

\section{Wirkung föderaler Strukturen und ihre Politikimplikationen}

\author{
(mit Kilian Bizer) \\ Veröffentlicht in: Wirtschaftsdienst, 95. Jg. (2015), H. 6, S.411-416 \\ im Juni 2015 \\ Copyright (c ZBW und Springer-Verlag Berlin Heidelberg \\ http://link.springer.com/article/10.1007/s10273-015-1840-9 \\ DOI: $10.1007 / \mathrm{s} 10273-015-1840-9$
}




\section{Abstract}

Federalism and public innovation support: Effects and policy implications: Public innovation support claims to reach out to firms with barriers to innovate, especially smaller firms. Earlier studies showed that governmental programmes do not reach those aims. But the distinction between different political levels introducing programmes was rarely analysed. Our empirical evidence from Germany and Europe shows that regional programmes and decentralized structures reach smaller companies better than national or European level programmes. Empirical evidence of the effectiveness of public support from different levels is less clear. Policy makers have to consider a trade-off between a bigger variety of firms supported and a reduced effectiveness of public support.

\section{Keywords}

Innovation, innovation policy, federalism, subsidies, Germany, Europe

\section{JEL Classification}

$\mathrm{O} 31, \mathrm{O} 38, \mathrm{H} 77$ 
Zur Steigerung der Wettbewerbsfähigkeit unterstützen viele europäische Länder aktiv privatwirtschaftliche Innovationstätigkeiten. Unabhängig davon, ob man den Koalitionsvertrag auf Bundesebene, die Koalitionsverträge in den Bundesländern oder die Zielsetzungen auf europäischer Ebene betrachtet, nimmt die Forderung nach der Erhöhung der Innovationskraft eine prominente Stelle ein.

In Zahlen ausgedrückt bedeutet dies, dass europaweit im Jahr 2010 allein von den Nationalstaaten rund 9,7 Milliarden Euro als direkte oder indirekte Hilfsmaßnahmen für Forschung, Entwicklung und Innovation bei der Europäischen Union hinterlegt waren (siehe Tabelle 1 für die absoluten und relativen Werte der Fördermaßnahmen der einzelnen EUMitgliedsstaaten). Dies entspricht $14,5 \%$ der generell ausgewiesenen staatlichen Unterstützungsmaßnahmen (Hilfen für Krisen sind in diesen Maßnahmen nicht eingeschlossen). Die Entwicklung dieser Innovationsförderung unterscheidet sich innerhalb der Mitgliedsstaaten der Europäischen Union stark: Während der Anteil der Innovationsfördermaßnahmen in Deutschland zwischen 2007 und 2012 um 4,4 Prozentpunkte zugenommen und in Frankreich im gleichen Zeitraum um 4,2 Prozentpunkte abgenommen hat, kam es in Belgien zu einem deutlichen Rückgang um 12,8 Prozentpunkte. Rumänien weist einen Rückgang von prozentual nur 2,0 Prozentpunkten auf, der jedoch die Innovationsförderung in absoluten Zahlen auf einen Wert nahe Null zurückgehen ließ. Im gleichen Zeitraum erhöhte Portugal den Anteil seiner staatlichen Innovationsfördermaßnahmen um 21,9 Prozentpunkte. Auch in anderen Mitgliedsstaaten wie Luxemburg (Erhöhung um 19,8 Prozentpunkte) oder Spanien (Erhöhung um 4,9 Prozentpunkte) ist ein Anstieg zwischen 2007 und 2012 belegt.

Bei der Untersuchung der Wirkung dieser Innovationsförderung wurde in der Vergangenheit häufig angenommen, dass die Förderpolitik in den jeweiligen Ländern einheitlich ist. ${ }^{1}$ Mit Blick auf sehr unterschiedliche politische Systeme, Geschichte und Größe der Länder ist dies jedoch kritisch zu hinterfragen: Insbesondere in föderalen oder semiföderalen - aber auch in einigen zentralistischen - Ländern innerhalb der Europäischen Union kommt regionalen Förderprogrammen eine besondere und zunehmende Bedeutung zu.

Wenn die regionalen Förderprogramme in Deutschland exakt identische Ziele abdecken würden wie die nationalen Förderprogramme, z.B. das Zentrale Innovationsprogramm Mittelstand (ZIM) des Bundesministeriums für Wirtschaft und Energie (BMWi), würde dies ausschließlich zusätzliche Verwaltungsstrukturen schaffen und wäre keine sinnvolle föderale Aufgabenteilung.

\footnotetext{
1 Vgl. exemplarisch K. Hussinger: R\&D and Subsidies at the Firm Level. An Application of Parametric and Semiparametric Two-Step Selection Models, in: Journal of Applied Econometrics, 23. Jg. (2008), H. 6, S. 729-747.
} 
Tabelle 1: Staatliche Innovationshilfen 2012 (absolut in Million $€$, relativ als Anteil in $\%$ zu allen Hilfen)

\begin{tabular}{|c|c|c|}
\hline Land & Absolut & Relativ \\
\hline$E U-27$ & $9.732,44$ & $14,49 \%$ \\
\hline Österreich (AT) & 227,78 & $15,53 \%$ \\
\hline Belgien (BE) & 416,61 & $22,50 \%$ \\
\hline Bulgarien (BG) & 1,60 & $2,08 \%$ \\
\hline Zypern (CY) & 1,35 & $1,14 \%$ \\
\hline Tschechische Republik (CZ) & 270,90 & $17,68 \%$ \\
\hline Dänemark (DK) & 211,45 & $8,12 \%$ \\
\hline Deutschland (DE) & $2.253,28$ & $18,98 \%$ \\
\hline Estland (EE) & 0,11 & $0,18 \%$ \\
\hline Griechenland (EL) & 4,10 & $0,21 \%$ \\
\hline Spanien (ES) & 764,21 & $19,38 \%$ \\
\hline Finnland (FI) & 230,47 & $8,69 \%$ \\
\hline Frankreich (FR) & $2.108,19$ & $14,07 \%$ \\
\hline Ungarn (HU) & 161,36 & $15,01 \%$ \\
\hline Irland (IE) & 94,90 & $10,87 \%$ \\
\hline Italien (IT) & $1.030,77$ & $17,98 \%$ \\
\hline Luxemburg (LU) & 41,84 & $43,50 \%$ \\
\hline Litauen (LT) & 10,44 & $4,48 \%$ \\
\hline Lettland (LV) & 0,87 & $0,25 \%$ \\
\hline Malta (MT) & 0,75 & $0,72 \%$ \\
\hline Niederlande (NL) & 457,10 & $19,03 \%$ \\
\hline Polen (PL) & 93,85 & $3,42 \%$ \\
\hline Portugal (PT) & 209,42 & $22,75 \%$ \\
\hline Rumänien (RO) & 8,54 & $1,03 \%$ \\
\hline Schweden (SE) & 119,82 & $3,71 \%$ \\
\hline Slowenien (SI) & 80,10 & $17,83 \%$ \\
\hline Slowakische Republik (SK) & 11,80 & $9,03 \%$ \\
\hline Vereinigtes Königreich (UK) & 920,75 & $18,73 \%$ \\
\hline
\end{tabular}

Daten: European Commission 2013 State Aid Scoreboard, eigene Berechnungen. 
Untersuchungen hierzu sind in Europa nur begrenzt vorhanden. Einzelne Untersuchungen in Deutschland sowie im europäischen Ausland in Spanien und insbesondere Katalonien und mit Abstrichen im baltischen und skandinavischen Ostseeraum sind vorhanden. ${ }^{2}$ In einer umfassenden Evaluation des ZIM werden auch die verschiedenen Programme der deutschen Bundesländer beleuchtet. Die entsprechende Studie belegt, dass alle Bundesländer - mit Ausnahme von Baden-Württemberg - zum Zeitpunkt der Analyse neben diversen technologiespezifischen Programmen solche zur allgemeinen Innovationsförderung privater Unternehmen anboten. $^{3}$ Gleichzeitig ist mit Blick auf die angestrebte Vielfältigkeit der regionalen Förderlandschaft festzuhalten, dass neben zweifelsfrei regionalen Besonderheiten, wie der Förderung der Luft- und Raumfahrt in Bremen oder der Schaffung von Institutionen zur Vernetzung der Forschung in Ostdeutschland auch überschneidende Programme auf Landesebene feststellbar sind: Es ist zumindest zweifelhaft, ob wirklich fast jedes deutsche Bundesland einen Schwerpunkt auf nanotechnologische Forschung oder Energieeffizienz aufgrund seiner regionalen Besonderheiten rechtfertigen kann oder ob hier nicht eher eine stärkere Bündelung auf Bundesebene effektiver wäre.

$\mathrm{Da}$ jedoch wenige Analysen zur Zielerreichung der unterschiedlichen Programmebenen vorliegen, steht genau die Beleuchtung dieser Fragestellung, welche Effekte sich durch föderale Strukturen auf die Vielfalt der geförderten Unternehmen und auf die Effektivität der Förderung ergeben. Dabei betrachtet der Artikel Deutschland und Europa getrennt.

\section{Unterschiedliche Charakteristika geförderter Unternehmen in Deutschland}

Bei der Analyse staatlicher Innovationsförderung sind unabhängig vom gewählten Kriterium immer Selektionsmechanismen zu berücksichtigen: Mit Blick auf die spätere Evaluation von Programmen besteht die Gefahr, dass die verantwortlichen Institutionen von vorneherein diejenigen Unternehmen fördern, bei denen sie eine größere Wahrscheinlichkeit auf Erfolg

${ }^{2}$ L. Becker: No gains of federalism in innovation support? The case of Germany, in: DRUID society (Hrsg.): Conference Proceedings 35th DRUID Celebration Conference 2013, http://druid8.sit.aau.dk/druid/acc_papers/ rv1s78ke8jm7n4Irad6udnov2bld.pdf (30.3.2015);

A. Fernández-Ribas: Public support to private innovation in multi-level governance systems: an empirical investigation, in: Science and Public Policy, 36. Jg. (2009), S. 457-467;

A. Vitola: Innovation policy mix in a multi-level context. The case of the Baltic Sea Region countries, in: Science and Public Policy (2014).

${ }^{3}$ M. Kulicke et al.: Evaluierung des Programmstarts und der Durchführung des "Zentralen Innovationsprogramms Mittelstand (ZIM)". Endbericht, Karlsruhe/Berlin 2010, S. 79. 
vermuten. ${ }^{4}$ Dieser Effekt kann zu Verzerrungen insbesondere bei der Messung der Effektivität von Fördermaßnahmen führen und ist deshalb besonders bei den Politikimplikationen zu berücksichtigen.

Die Förderlandschaft in Deutschland ist dadurch geprägt, dass es mit den deutschen Bundesländern starke regionale Akteure gibt. Das spiegelt sich auch teilweise in der Förderung auf europäischer Ebene wider: Für diverse europäische Förderprogramme, die auch Innovationsförderung betreiben dienen Bundesländer als ausführende Institutionen. Mit Blick auf die Innovationsförderung stellt das ZIM des Bundes jedoch mit deutlichem Abstand das größte finanzielle Volumen.

Beachtenswert ist, dass auch fünfundzwanzig Jahre nach der deutschen Wiedervereinigung eine Vielzahl von Programmen speziell die ostdeutschen Bundesländer fördert. Aufgrund der sehr unterschiedlichen Wirtschaftsstrukturen erscheint dies angemessen, da in den ostdeutschen Bundesländern Großunternehmen mit starken Innovationsstrukturen, die als Anker für andere innovationstätige Unternehmen dienen können, noch immer fehlen und dies durch staatliche Einrichtungen und Fördermaßnahmen zumindest teilweise kompensiert werden soll. ${ }^{5}$

All diese Aspekte der Vielfalt der Innovationsförderung in föderalen Staaten leiten zur empirischen Untersuchung der verschiedenen Förderebenen. Im Gegensatz zu früheren Studien ${ }^{6}$ untersucht dieses Paper dabei die gesamte Förderung in Deutschland nicht wie einen monolithischen Block, sondern unterscheidet die drei Ebenen der Förderung: Regionale (Landes-)Förderung, nationale (Bundes-)Förderung und europäische (EU-)Förderung.

Dies geschieht mittels binärer Regressionen (für Deutschland mittels Logit-Regressionen), da die entsprechenden abhängigen Variablen des Erhalts der Förderung von der jeweiligen Ebene binär kodiert sind. Zur besseren Interpretierbarkeit dienen neben den Koeffizienten auch die Odds Ratios bei den Logit-Regressionen.

4 Vgl. D. Radicic, G. Pugh: The impact of innovation support programmes on SME innovation in traditional manufacturing industries. an evaluation for seven EU regions, in: DRUID society (Hrsg.): Conference Proceedings DRUID Academy 2013 2013, $\quad$ S. 20, http://druid8.sit.aau.dk/acc_papers/bqon0p6k7nppx07f6gk96qmm0cte.pdf (15.10.2014);

vgl. U. Cantner, S. Kösters: Picking the Winner? Empirical Evidence on the Targeting of R\&D Subsidies to Start-Ups, in: Small Business Economics, 39. Jg. (2012), H. 4, S. 921-936, S. 932 f..

${ }^{5} \mathrm{H}$. Belitz, A. Eickelpasch, A. Lejpras: Technologieoffene Förderung - Zentrale Stütze der Industrieforschung in Ostdeutschland, in: Wochenbericht des DIW Berlin, 77. Jg. (2010), 51-52, S. 2-10, S. 4.

${ }^{6}$ D. Czarnitzki, A. Fier: Do Innovation Subsidies Crowd Out Private Investment? Evidence from the German Service Sector, in: Applied Economics Quarterly (Konjunkturpolitik), 48. Jg. (2002), H. 1, S. 1-25;

K. Hussinger: R\&D and Subsidies at the Firm Level. An Application of Parametric and Semiparametric Two-Step Selection Models, in: Journal of Applied Econometrics, 23. Jg. (2008), H. 6, S. 729-747. 
Als erklärende Variablen dienen dabei verschiedene Firmencharakteristika, wie Unternehmensgröße, Ausgaben für Forschung und Entwicklung, aber auch die Lage des Unternehmens in Deutschland. Für alle Regressionen in Deutschland wird das Mannheim Innovation Panel des Zentrums für Europäische Wirtschaftsforschung (ZEW) mit Daten aus dem Jahr 2007 verwendet. ${ }^{7}$ Es handelt sich hierbei, um ein unbalanciertes Panel, so dass wir die Daten in den Regressionen als Querschnittsdaten verwenden, um die Anzahl der Beobachtungen nicht zu reduzieren. Insgesamt befinden sich so 1.259 Firmen aus ganz Deutschland in unserer Stichprobe.

Tabelle 2 stellt neben den Erklärungen aller Variablen auch die Ergebnisse der drei logistischen Regressionen dar:

- Wie erwartet stellen wir einen signifikanten Effekt für Firmen mit Sitz in Ostdeutschland (east) fest, der sowohl bei regionalen als auch bei nationalen Maßnahmen positiv verläuft. Lediglich für die Europäische Union erscheint dieser Koeffizient negativ, wenn auch weniger signifikant - was mit dem höheren Koordinierungsbedarf und einhergehenden Problemen für die kleinteiligeren Strukturen in Ostdeutschland erklärt werden kann. ${ }^{8}$ Neben dieser regionalspezifischen ostdeutschen Perspektive ist der negative, wenn auch nur schwach signifikante Koeffizient für Firmen aus Geberländern des Länderfinanzausgleichs (donor) bei regionalen Programmen beachtenswert. In diesen Ländern stehen offensichtlich für die Firmen insgesamt weniger regionale Programme zur Verfügung oder diese sind schwerer zu erreichen.

- Ein schwach signifikanter negativer Koeffizient für die Förderung kleiner und mittlerer Unternehmen (sme) durch die europäische Ebene zeigt, dass die europäische Förderung kleine und mittlere Unternehmen (KMU) schlechter als Großunternehmen erreicht. Der Koeffizient ist auch auf nationaler Ebene für KMU negativ, wenn auch nicht signifikant, was die Erkenntnis der europäischen Ebene unterstreicht. Er erreicht zwar ebenfalls keine Signifikanz bei regionalen Programmen, zeigt jedoch ein positives Vorzeichen, was den empirischen Ergebnissen aus anderen föderalen Ländern entspricht und aufzeigt, dass regionale Programme in föderalen Staaten kleine und mittlere Unternehmen besser erreichen als nationale oder supranationale Programme.

\footnotetext{
7 ZEW: Mannheim Innovation Panel (MIP), Mannheim.

8 In den direkten Programmen der Europäischen Union wird zum Beispiel häufig eine Kooperation mit Institutionen aus mindestens zwei anderen Mitgliedsländern der EU vorausgesetzt. Dieses Ziel ist für global agierende Großunternehmen erheblich leichter zu erreichen als für mittelständische Unternehmen, die den Großteil der Unternehmen in Ostdeutschland ausmachen.
} 
- Für nationale und europäische Förderprogramme zeigen sowohl der Anteil der hochqualifizierten Beschäftigten (highedu) als auch die Kontinuität der Innovationstätigkeit (regular) hoch signifikante positive Koeffizienten, wohingegen diese Faktoren in regionalen Programmen durch fehlende Signifikanz und erheblich niedrigere Koeffizienten auffallen. Relevant und positiv auf allen Ebenen ist die Höhe der finanziellen Aufwendungen der Unternehmen für Innovationen (logarithmiert in Inrdexp).

- Die Position am Markt ist insbesondere für nationale und supranationale Programme relevant: Während ein höherer Grad an Qualitätswettbewerb (qualcomp) einen signifikanten und positiven Koeffizienten auf nationaler Ebene zeigt, ist auf europäischer Ebene die positive Wirkung eines höheren Marktanteils (mshare) und die negative Wirkung einer Ausrichtung auf nationale Märkte (national) signifikant sichtbar. Der ebenfalls negative Koeffizient für internationale Marktausrichtung (international) ist nicht signifikant. Beide Marktausrichtungskoeffizienten unterscheiden sich auf europäischer Ebene in ihrer negativen Ausrichtung von den Koeffizienten in den Regressionen für regionale und nationale Förderprogramme.

Zusammenfassend stellen wir für Deutschland aus den Ergebnissen der Regressionen fest, dass die Programme auf regionaler, nationaler und europäischer Ebene unterschiedliche Zielgruppen ansprechen, da die erklärenden Variablen deutliche Unterschiede aufzeigen. Somit kommt es nicht zu einer massiven Überlappung. Insbesondere für die Förderung von KMU erscheint ein breiteres Angebot unterschiedlicher Ebenen durchaus sinnvoll. Das bedeutet, dass es im Bereich der Innovationsförderung im föderalen Gefüge zu einer sinnvollen Arbeitsteilung kommt. 
Tabelle 2: Eigenschaften geförderter Unternehmen in Deutschland (logistische Regression, Logit) ${ }^{9}$

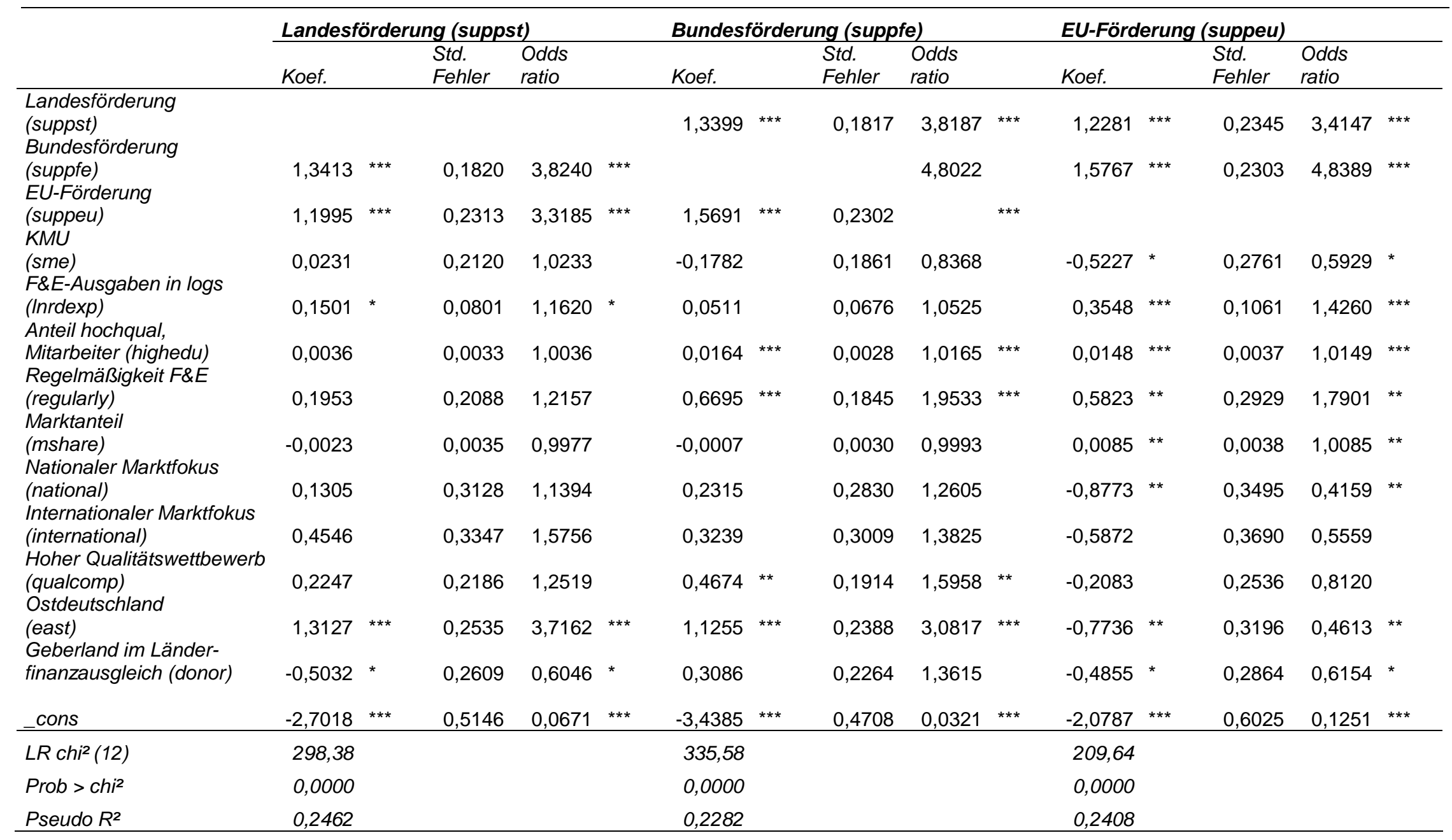

Daten: MIP 2007, Bemerkungen: Berechnet mit Stata; ${ }^{* \star *}$ Signifikanz auf $1 \%$ Niveau ** auf $5 \%$ Niveau; * auf $10 \%$ Niveau.

${ }^{9}$ Vgl. L. Becker: No gains of federalism in innovation support? The case of Germany, in: DRUID society (Hrsg.): Conference Proceedings 35th DRUID Celebration Conference 2013, S. 12, http://druid8.sit.aau.dk/druid/acc_papers/rv1s78ke8jm7n4Irad6udnov2bld.pdf (30.3.2015). 


\section{Föderale und semiföderale Strukturen begünstigen kleine und mittlere Unternehmen in Europa}

Auf europäischer Ebene lassen sich anhand von Daten der Community Innovation Survey (CIS) von Eurostat aus dem Jahr 2008 ähnliche Schlüsse für sechzehn Mitgliedsstaaten der Europäischen Union ziehen. ${ }^{10}$ Zur Untersuchung der Auswirkung föderaler Strukturen ordnen wir hierzu die Nationen wie in Tabelle 3 den Kategorien föderal, semiföderal und zentralistisch zu. Als semiföderale Nationen werden hierbei Staaten bezeichnet, die weder klar dezentralisierte und föderale Strukturen, noch klar zentralisierte und zentralistische Strukturen besitzen.

Regionale Programme in föderalen oder semiföderalen Nationen erreichen kleine und mittlere Unternehmen besser als zentralisierte und zentralistische Strukturen. Zentralistische EUMitgliedsländer hingegen erreichen nur bei Komponenten der europäischen Förderung einen positiven Effekt für kleine und mittlere Unternehmen. Verglichen mit Großunternehmen haben kleine und mittlere Unternehmen europaweit beim Erhalt nationaler Förderung einen Nachteil. Dies gilt in semiföderalen und föderalen Nationen auch für den Erhalt europäischer Förderung. Andere Einflussfaktoren, wie die Kontinuität der Innovationstätigkeit, aber auch die Höhe der Ausgaben für diese, zeigen positive und signifikante Koeffizienten - hier allerdings auf allen Ebenen. Teilweise sind jedoch diese Berechnungen nur in vierzehn oder fünfzehn EUMitgliedsstaaten möglich, da nicht für alle Nationen vollständige Daten vorliegen.

Anders als in Deutschland zeigen die Koeffizienten für Marktausrichtungen keine eindeutige Tendenz in den Länderstudien in Europa.

Deutliche Unterschiede zwischen den verschiedenen politischen Systemen - föderal, semiföderal und zentralistisch - treten in der Analyse hervor. Insbesondere der untersuchte Aspekt der Förderung kleiner und mittlerer Unternehmen wird hierbei vor allem durch regionale Programme semiföderaler und föderaler Länder erreicht.

\footnotetext{
${ }^{10}$ L. Becker, K. Bizer: Federalism and innovation support for small and medium-sized enterprises. Empirical evidence in Europe 2015;

Eurostat: Community Innovation Survey (CIS), Luxemburg.
} 
Tabelle 3: Kategorisierung von Ländern nach Föderalismusgrad in der Europäischen Union ${ }^{11}$

\begin{tabular}{|c|c|c|}
\hline Föderal und dezentralisiert & Semiföderal & Zentralistisch und zentralisiert \\
\hline $\begin{array}{ll}\text { - } & \text { Belgien (seit 1993) } \\
\text { - } & \text { Deutschland }\end{array}$ & $\begin{array}{l}\text { - } \text { Österreich } \\
\text { - } \text { Dänemark } \\
\text { - } \text { Finnland } \\
\text { - Niederlande } \\
\text { - Spanien } \\
\text { - Schweden } \\
\text { - Vereinigtes Königreich (seit } \\
\text { 1998) }\end{array}$ & $\begin{array}{l}\text { - } \text { Bulgarien } \\
\text { - } \text { Tschechische Republik } \\
\text { - } \text { Estland } \\
\text { - } \text { Griechenland } \\
\text { - Ungarn } \\
\text { - Irland } \\
\text { - Italien } \\
\text { - Lettland } \\
\text { - Litauen } \\
\text { - Luxemburg } \\
\text { - Malta } \\
\text { - Portugal } \\
\text { - Rumänien } \\
\text { - Slowakische Republik } \\
\text { - Slowenien }\end{array}$ \\
\hline
\end{tabular}

Bemerkungen: Drei Unterkategorien aus der Originalquelle werden zu einer Kategorie „semiföderal“ aggregiert.

\section{Effektivität der Förderung in föderalen Systemen unklar}

Die Effektivität staatlicher Innovationsfördermaßnahmen untersuchen viele Studien anhand des Kriteriums der Additionalität der Förderung. Untersuchungen für Deutschland bestätigen eine Additionalität, obgleich in unterschiedlicher Höhe. Diese reicht von 0,28 Euro zusätzlicher privater Innovationsaktivitäten pro Euro staatlicher Förderung ${ }^{12}$ bis zu einem Euro zusätzlicher privater Innovationsaktivitäten pro Euro staatlicher Förderung. ${ }^{13}$ Auch in anderen europäischen Ländern zeigt sich ein ähnliches Bild mit zumindest teilweiser Additionalität.

\footnotetext{
11 Vgl. A. Lijphart: Patterns of democracy. Government forms and performance in thirty-six countries, New Haven 2012, S. 178;

vgl. A. Roberts: What Kind of Democracy Is Emerging in Eastern Europe?, in: Post-Soviet Affairs, 22. Jg. (2006), H. 1, S. 37-64, S. 44.

12 A. Fier, D. Czarnitzki: Zum Stand der empirischen Wirkungsanalyse der öffentlichen Innovations- und Forschungsförderung, $\quad$ S. $4, \quad$ http://www.zew.de/de/publikationen/evaluationinno/ZEW_Ueberblick_ Wirkungsanalyse.pdf (11.3.2015).

${ }^{13}$ K. Hussinger: R\&D and Subsidies at the Firm Level. An Application of Parametric and Semiparametric Two-Step Selection Models, in: Journal of Applied Econometrics, 23. Jg. (2008), H. 6, S. 729-747, S. 743.
} 
Da Innovationen nicht Selbstzweck, sondern vielmehr das Mittel zu Erreichung des Zwecks höherer Wettbewerbsfähigkeit sein sollen, kann die Frage der Effektivität nicht auf die Frage der Additionalität beschränkt bleiben: ${ }^{14}$ So analysiert sie zwar die Gefahr eines möglichen CrowdingOut, beantwortet aber nicht die Frage, ob durch eine Innovation wirklich die Wettbewerbsfähigkeit eines Unternehmens oder Landes erhöht wird.

Die Effekte, die bei Untersuchungen zu Wachstumspfaden, Arbeitsproduktivität oder Innovationstätigkeit in verschiedenen europäischen Ländern und im europäischen Vergleich sichtbar werden, sind eher als gering beziehungsweise unklar einzustufen.

Zur Analyse dieser Fragestellung in Deutschland nutzen wir erneut das Mannheim Innovation Panel aus 2007 mittels logistischer Regressionen. In diesen Regressionen besteht die Stichprobe aus 6.069 Beobachtungen. Diesmal dienen die Förderungen der drei Ebenen (suppst, suppfe, suppeu) jedoch als erklärende Variablen der abhängigen Variablen für Anstieg respektive Absinken von Umsatz (turnup, turndown) sowie Umsatzrendite (rosup, rosdown).

Wie Tabelle 4 zeigt, sind die Ergebnisse in Deutschland auf den verschiedenen Förderebenen nicht eindeutig. Für regionale und europäische Fördermaßnahmen zeigt sich kein gewünschter Effekt, dieser wird nur für nationale Programme bei Entwicklung von Umsatzrendite und Umsatz sichtbar.

Im europäischen Vergleich ist ein gewünschter Effekt nur bei der Arbeitsproduktivität ableitbar. Effekte bei der Entwicklung der Beschäftigtenzahlen und der Umsatzentwicklung laufen eher auf einen Rückgang hinaus. Klare Ländereffekte für föderale, semiföderale und zentralistische Länder lassen sich nicht finden. ${ }^{15}$

Zusammenfassend ist mit Blick auf die Effektivität ein unklarer Nutzen für föderale Strukturen festzustellen und nach ersten Erkenntnissen für Deutschland insbesondere auch eine Untersuchung der Maßnahmen der Bundesländer und der Europäischen Union notwendig.

\footnotetext{
${ }^{14}$ Vgl. G. Cerulli: Modelling and Measuring the Effect of Public Subsidies on Business R\&D. A Critical Review of the Econometric Literature, in: The economic record : er, 86. Jg. (2010), H. 274, S. 421-449.

${ }^{15} \mathrm{~L}$. Becker: Effectiveness of public innovation support in Europe. Does public support foster turnover, employment and labour productivity?, http://wwwuser.gwdg.de/ cege/Diskussionspapiere/DP236.pdf (26.3.2015)
} 
Tabelle 4: Wirkung staatlicher Förderung auf Umsatz und Umsatzrendite (logistische Regression, Logit) ${ }^{16}$

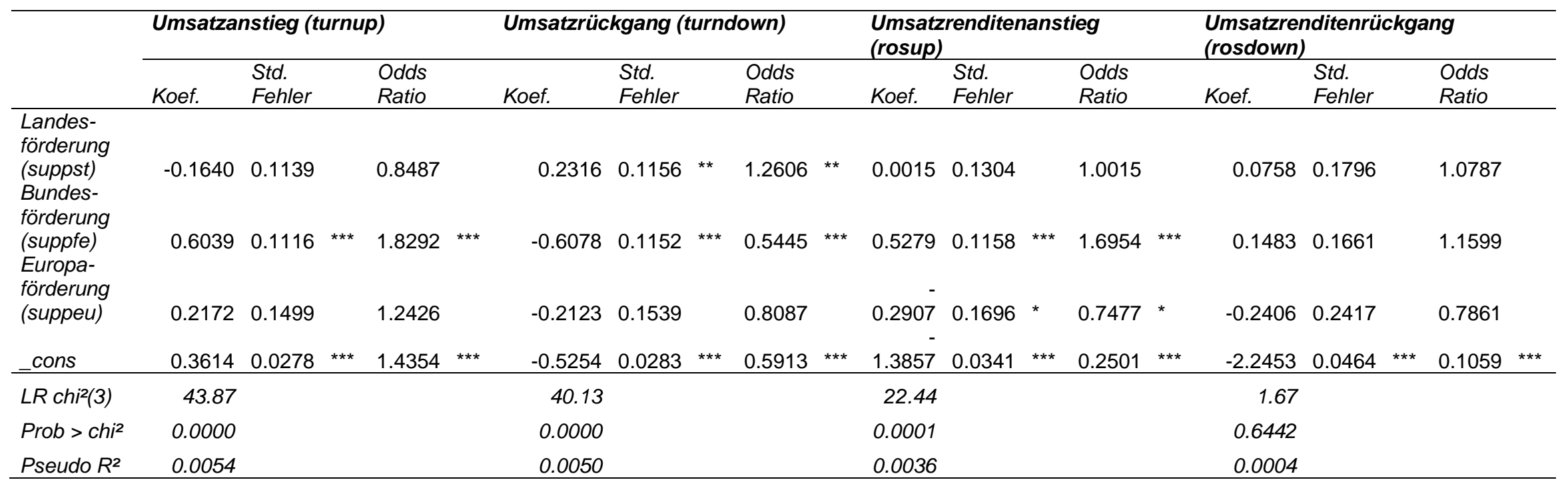

Daten: MIP 2007; Bemerkungen: Berechnet mit Stata; ${ }^{* \star}$ Signifikanz auf $1 \%$ Niveau ** auf $5 \%$ Niveau; ${ }^{*}$ auf $10 \%$ Niveau.

${ }^{16}$ Vgl. L. Becker: No gains of federalism in innovation support? The case of Germany, in: DRUID society (Hrsg.): Conference Proceedings 35th DRUID Celebration Conference 2013, S. 13, http://druid8.sit.aau.dk/druid/acc_papers/rv1s78ke8jm7n4lrad6udnov2bld.pdf (30.3.2015) 


\section{Folgen für politisches Handeln}

Aus den Analysen der Charakteristika der Unternehmen ergeben sich wie auch aus den Erkenntnissen zur Effektivität der staatlichen Innovationsförderung Folgen für politisch Handelnde. Die Politik strebt einerseits eine große Vielfalt geförderter Unternehmen, besonders kleinerer Unternehmen, an und verfolgt andererseits das Ziel, möglichst effektiv zu fördern.

Die unterschiedlichen Charakteristika der von den drei Ebenen geförderten Unternehmen in Deutschland ebenso wie die Effekte für kleine und mittlere Unternehmen im europäischen Vergleich machen deutlich, dass semiföderale und föderale Systeme KMU besser erreichen und so Barrieren zur Innovationstätigkeit umfassender reduzieren als es zentralistische Systeme oder nationale Programme allein könnten.

Dies spricht grundsätzlich für eine Aufgabenteilung und Koordinierung zwischen den Ebenen und gegen eine starke Überlappung der unterschiedlichen Programmebenen mit entsprechenden Wohlfahrtsverlusten. Dennoch wäre eine weitergehende Fokussierung der regionalen Programme auf die spezifischen Gegebenheiten, wie sie zum Beispiel bereits heute in Teilen Ostdeutschlands erfolgreich praktiziert wird, für alle Bundesländer sinnvoll, um die Effektivität der Förderung zu erhöhen.

Mit Blick auf die Effektivität erscheint eine Fokussierung auf der nationalen Ebene vorteilhafter. Jedoch bleiben die empirischen Ergebnisse hierbei unklar. Zu beachten ist ferner, dass durch Selektionsprobleme insbesondere die Schwerpunktsetzung auf kleinere Unternehmen per se zu einem Rückgang der Effektivität der Förderung führen kann. Die Wahrscheinlichkeit, dass größere Unternehmen sowohl innovationstätiger als auch erfolgreicher und wettbewerbsfähiger sind und deshalb eher für Programme ausgewählt werden, ist hierbei von politisch Handelnden zu berücksichtigen.

Politische Entscheider müssen die Abwägung zwischen größerer Vielfalt der geförderten Unternehmen oder größtmöglicher Effektivität der Förderung treffen.

Zusammenfassend und abwägend lässt sich eine positive Wirkung föderaler Förderstrukturen belegen, obgleich damit Verluste bei der Effektivität verbunden sein können. 